\title{
Desenvolvimento de Compósitos de Borracha Nitrilica Reforçados com Fibras de Sisal
}

\author{
Marco Antonio Iozzi
}

Dissertação apresentada à Área de Interunidades em Ciência e Engenharia de Materiais, da Universidade de São Paulo, para obtenção do título de Mestre em Ciências e Engenharia de Materiais.

Orientador: Prof. Dr. Luiz Henrique Capparelli Mattoso 
Iozzi, Marco Antonio

"Desenvolvimento de compósitos de borracha nitrílica reforçados com fibras de sisal"

Marco Antonio Iozzi - São Carlos, 2003

Dissertação (Mestrado) - Área de Interunidades em Ciência e Engenharia de Materiais, da Universidade de São Paulo, 2003 - Páginas: 89

Orientador: Prof. Dr. Luiz Henrique Capparelli Mattoso

1. Compósitos; 2. Borracha nitrílica; 3. Sisal; 4. Carbonato de cálcio

I. Título 
MEMBROS DA COMISSÃO JULGADORA DA DISSERTAÇÃO DE MESTRADO DE MARCO ANTONIO IOZZI, APRESENTADA À ÁREA INTERUNIDADES CIÊNCIA E ENGENHARIA DE MATERIAIS, UNIVERSIDADE DE SÃO PAULO, EM 26/05/2003.

COMISSÃO JULGADORA:

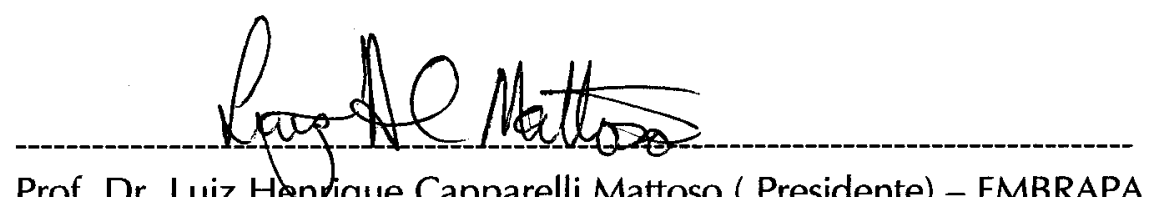

Prof. Dr. Luiz Henrique Capparelli Mattoso ( Presidente) - EMBRAPA

Prof. Dr. Elias Hage Junior - UFSCar

Elvoabete Indlimi

Profa. Dra. Elisabete Frollini - IQSC-USP 
A Deus, pela existência.

À minha Familia pelo constante incentivo e apoio; pela serenidade sempre transmitida; por todo amor dedicado.

SENHOR, a noite veio e a alma é vil.

Tanta foi a tormenta e a vontade!

Restam-nos hoje, no silêncio hostil,

O mar universal e a saüdade.

Mas a chamma, que a vida em nós creou,

Se ainda ha vida ainda não é finda.

O frio morto em cinzas a ocultou:

A mão do vento pode erguel-a ainda.

Dá o sopro, a aragem, - ou desgraça ou ancia -,

Com que a chamma do esforço se remoça,

E outra vez conquistemos a Distância -

Do mar ou outra, mas que seja nossa!

("Prece" - Fernando Pessoa) 


\section{AGRADECIMENTOS}

- Ao Dr. Luiz Henrique Caparelli Mattoso, pela confiança depositada, pelo apoio e orientações sempre presentes.

- À 3M do Brasil Ltda., aqui representada especialmente na pessoa de Ranjit Thakur, pela abertura e incentivo ao Programa de Pós-Graduação na Empresa.

- Ao Gilson, companheiro de todos os dias, por seu espírito incentivador, e pelo acompanhamento em todas as fases deste projeto.

- A Maria Alice, um agradecimento especial por sua sempre presente disposição a colaborar em diversos aspectos deste trabalho.

- A $\mathrm{Dr}^{\mathrm{a}}$ Regina Helena Porto Francisco, meu primeiro contato neste programa de pós-graduação, por sua cordial acolhida e orientações.

- Ao Joel, pela contribuição no corte das fibras e no design gráfico.

- A Wladerez e Cristiane, pela prestatividade e apoio.

- Ao Dr. Fábio Cezar Ferreira (UNESP - Presidente Prudente) pelas medidas de TG e DSC.

- Ao Gallo, pelas medidas de microscopia eletrônica.

- A todos que direta ou indiretamente contribuíram para a realização deste trabalho. 


\section{SUMÁRIO}

LISTA DE FIGURAS

LISTA DE TABELAS …………................................................................ iv

RESUMO

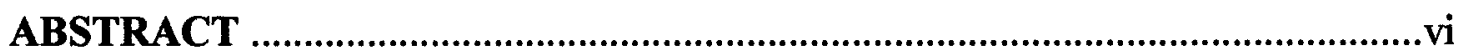

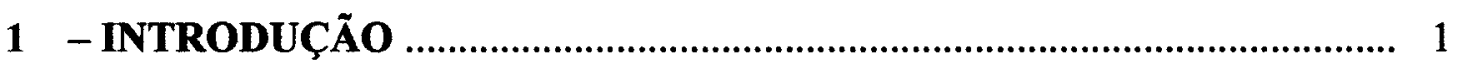

\section{2 - FUNDAMENTOS TEÓRICOS E REVISÃO BIBLIOGRÁFICA}

2.1 - Materiais Compósitos ……................................................................... 3

2.1.1 - Materiais Compósitos Fibrosos …………………....................................... 4

2.1.2 - Materiais Compósitos Particulados ……………………………………... 7

\section{2-Sisal}

2.2.1 - O Sisal no Cenário Nacional ................................................................ 8

2.2.2 - Ciclo, Corte e Beneficiamento das Folhas de Sisal .................................. 10

2.2.3 - Composição Quimica das Fibras de Sisal ................................................. 12

2.2.4 - O Sisal em Materiais Compósitos .............................................................. 18

\section{3 - Borracha Nitrílica}

2.3.1 - Histórico da Borracha Natural e Sintética ............................................... 20

2.3.2 - Propriedades da Borracha Nitrílica e suas aplicações em compósitos .... 21

$$
\begin{gathered}
\text { IFSC-USP SERVICOODE BIBLIOTECA } \\
\text { INFORMACÁO }
\end{gathered}
$$


2.3.3 - Processamento por Calandragem

2.4 - Carbonato de Cálcio

3 - OBJETIVOS

\section{4 - EXPERIMENTAL}

\section{1 - Materiais}

4.1.1 - Fibras de Sisal

4.1.2 - Borracha Nitrílica 30

4.1.3 - Carbonato de Cálcio 30

4.1.4 - Aditivos

4.1.5 - Reagentes, grau analítico

\section{2 - Métodos}

4.2.1 - Rota Experimental 32

4.2.2 - Tratamentos das Fibras de Sisal 33

4.2.3 - Corte das Fibras de Sisal 34

4.2.4 - Microscopia Eletrônica de Varredura (MEV) 34

4.2.5 - Preparação dos Compósitos

4.2.5.1 - Composição 35

4.2.5.2 - Processamento dos Compósitos 36

4.2.6 - Ensaios de Resistência à Tração 37

4.2.7 - Análise Termogravimétrica (TG) 38

4.2.8 - Calorimetria Exploratória Diferencial (DSC) 38 
5.1 - Análise Microscópica das Fibras de Sisal por MEV

5.2 - Corte das Fibras de Sisal

5.3 - Propriedades Mecânicas sob Tração dos Compósitos

5.3.1 - Estudo da Variação do Teor de Carbonato de Cálcio sobre Borracha 45

5.3.2 - Estudo da Variação do Tamanho de Fibra de Sisal 48

5.3.3 - Efeito do Tratamento da Fibra de Sisal nos Compósitos 53

5.3.4 - Efeito do Teor de Fibra de Sisal Mercerizado nos Compósitos 59

5.4 - Microscopia Eletrônica de Varredura dos Compósitos 63

5.5 - Análise Térmica dos Compósitos 66

6 - CONCLUSÕES E OBSERVAÇÕES EXPERIMENTAIS IMPORTANTES 76

7 - ANEXOS 78

8 - REFERÊNCIAS 80 


\section{LISTA DE FIGURAS}

Figura 1 - Estrutura molecular da celulose. …............................................. 14

Figura 2 - Fórmula dos açúcares constituintes das polioses. .......................... 16

Figura 3 - Principais precursores da lignina ................................................ 16

Figura 4 - Modelo estrutural de lignina de folhosa (Fagus sylvatica) apresentada por Nimz. ...................................................................................... 17

Figura 5 - Micrografia obtida por MEV da superficie longitudinal de uma fibra de sisal sem tratamento. Ampliação de 500 x ...................................... 40

Figura 6 - Micrografia obtida por MEV da superficie longitudinal de uma fibra de sisal lavada com água, durante 1 hora a $80^{\circ} \mathrm{C}$. Ampliação de $500 \mathrm{x}$. 40

Figura 7 - Micrografia obtida por MEV da superficie longitudinal de uma fibra de sisal tratada com solução de detergente neutro a $20 \%$, durante 1 hora a $80^{\circ} \mathrm{C}$. Ampliação de $500 \mathrm{x}$. 41

Figura 8 - Micrografia obtida por MEV da superfície longitudinal de uma fibra de sisal tratada com solução de água/acetona (1:1, v:v), durante 2 horas, $T$. ambiente. Ampliação de $500 \mathrm{x}$. 41

Figura 9 - Micrografia obtida por MEV da superficie longitudinal de uma fibra de sisal mercerizada com solução de $\mathrm{NaOH}$ a $10 \%$, durante 3 horas, $\mathrm{T}$. ambiente. Ampliação de 500 x. 42

Figura 10 - Micrografia obtida por MEV da superficie longitudinal de uma fibra de sisal mercerizada com solução de $\mathrm{NaOH}$ a $10 \%$, durante 5 horas, $\mathrm{T}$. ambiente. Ampliação de 500 x.

Figura 11 - Micrografia obtida por MEV da superfície longitudinal de uma fibra de sisal mercerizada com solução de $\mathrm{NaOH}$ a $10 \%$, durante 10 horas, $\mathrm{T}$. ambiente. Ampliação de 500 x. 43

Figura 12 - Distribuição percentual dos tamanhos de fibra obtidos para cada um dos quatro tamanhos nominais usados.

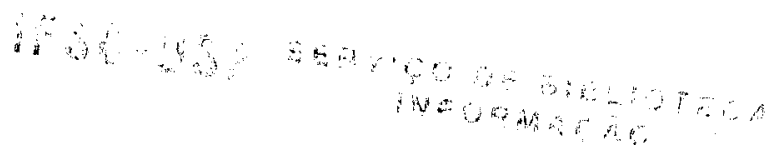


Figura 13 - Curvas de (a) \% de elongação na ruptura, (b) Tensão na ruptura e (c) Módulo de Elasticidade a $10 \%$, para o estudo da variação de teor de carbonato de cálcio sobre borracha nitrílica. 46

Figura 14 - Curvas representativas de Força (N) x Deformação (mm), obtidas em ensaios de tração. Estudo da variação do teor de carbonato de cálcio sobre borracha nitrílica. 47

Figura 15 - Curvas de (a) \% de elongação na ruptura, (b) Tensão na ruptura e (c) Módulo de elasticidade a $10 \%$, para o estudo da variação do tamanho de fibra de sisal lavada em água quente, sobre borracha nitrílica pura; borracha nitrílica com 33 pcr de carbonato; e borracha nitrílica com 67 pcr de carbonato

Figura 16 - Curvas obtidas em ensaios de tração. Estudo da variação do tamanho de fibra lavada sobre matriz de (a) borracha pura, (b) borracha com 33 pcr de carbonato, e (c) borracha com 67 pcr de carbonato. Mantido o teor de fibra em 22 pcr 52

Figura 17 - Curvas de (a) \% de elongação na ruptura, (b) Tensão na ruptura e (c) Módulo de elasticidade a $10 \%$, para o estudo da variação do tipo de tratamento da fibra de sisal, sobre borracha nitrílica pura; borracha nitrílica com 33 pcr de carbonato; e borracha nitrílica com 67 pcr de carbonato 54

Figura 18 - Curvas obtidas em ensaios de tração. Estudo da variação do tipo de tratamento da fibra sobre matriz de (a) borracha pura, (b) borracha com 33 pcr de carbonato, e (c) borracha com 67 pcr de carbonato. Mantido o teor de fibra em 22 pcr e o tamanho em $6 \mathrm{~mm}$ 58

Figura 19 - Curvas de (a) \% de elongação na ruptura, (b) Tensão na ruptura e (c) Módulo de elasticidade a $10 \%$, para o estudo da variação do teor da fibra de sisal mercerizado ( $\mathrm{NaOH} 10 \%, 3 \mathrm{~h}, \mathrm{~T}$. ambiente), sobre borracha nitrilica pura e borracha nitrílica com 67 pcr de carbonato. Fibras com $6 \mathrm{~mm}$ de comprimento 60

Figura 20 - Curvas obtidas em ensaios de tração. Estudo da variação do teor de fibra mercerizada sobre matriz de (a) borracha pura e, (b) borracha com 67 pcr de carbonato. Mantido o tamanho de fibra em $6 \mathrm{~mm}$ para as duas situações 62

Figura 21 - Micrografia obtida por MEV da superficie de fratura de compósitos de borracha nitrílica com fibras de sisal sem tratamento. Ampliação de 500 vezes 64

Figura 22 - Micrografia obtida por MEV da superficie de fratura de compósitos de borracha nitrílica com fibras de sisal lavadas em água quente. Ampliação de 500 vezes 64 
Figura 23 - Micrografia obtida por MEV da superficie de fratura de compósitos de borracha nitrilica com fibras de sisal mercerizadas. Ampliação de 500 vezes 65

Figura 24 - Micrografia obtida por MEV da superfície de fratura de compósitos de borracha nitrílica com carbonato de cálcio. Ampliação de 3.000 vezes 65

Figura 25 - Micrografia obtida por MEV da superfície de fratura de compósitos de borracha nitrílica com carbonato de cálcio e fibras de sisal mercerizadas. Ampliação de 500 vezes 66

Figura 26 - Curvas de TG para borracha nitrílica, e compósitos de borracha com carbonato, borracha com fibra de sisal, e borracha com fibra de sisal e carbonato 68

Figura 27 - Curva de TG para borracha nitrílica 68

Figura 28 - Curva de TG para o compósito de borracha nitrílica com carbonato de cálcio 69

Figura 29 - Curva de TG para o compósito de borracha nitrílica com fibras de sisal 70

Figura 30 - Curva de TG para o compósito de borracha nitrílica com fibras de sisal e carbonato de cálcio 70

Figura 31 - Curvas de DSC para borracha nitrílica, e compósitos de borracha com carbonato, borracha com fibra de sisal, e borracha com fibra de sisal e carbonato 73

Figura 32 - Curvas de DSC para borracha nitrílica, e compósitos de borracha com carbonato, borracha com fibra de sisal, e borracha com fibra de sisal e carbonato. Taxa de aquecimento de $10^{\circ} \mathrm{C} / \mathrm{min}$, fluxo de $\mathrm{N}_{2}$ de 30 $\mathrm{ml} / \mathrm{min}$. Ampliação na região da temperatura de transição vítrea da borracha nitrílica. 


\section{LISTA DE TABELAS}

Tabela I - Composição química da fibra de sisal apresentada por diferentes pesquisadores

Tabela II - Propriedades fisicas das borrachas nitrílicas 23

Tabela III - Formulações empregadas nas análises térmicas de TG e DSC 66 


\section{RESUMO}

A obtenção de compósitos elastoméricos resistentes a óleos e à abrasão, com propriedades mecânicas melhoradas através da incorporação de fibras naturais pelo processo de calandragem, é uma abordagem promissora que amplia as aplicações tecnológicas destes materiais e permite sua produção em escala industrial. Neste trabalho foram desenvolvidos compósitos de borracha nitrílica com fibras de sisal, e borracha nitrílica com carbonato de cálcio e fibras de sisal. Os compósitos foram processados em moinho de dois rolos, em condições otimizadas de processamento. Estudou-se a influência do teor de carbonato, tamanho e teor das fibras de sisal, bem como do tratamento de mercerização das fibras nas propriedades dos compósitos. Os compósitos, com as fibras curtas aleatoriamente distribuídas, foram caracterizados através de ensaios mecânicos, microscopia eletrônica de varredura (MEV), análise termogravimétrica (TG) e calorimetria exploratória diferencial (DSC). $\mathrm{O}$ tratamento de mercerização promoveu a remoção de lignina e hemicelulose da superfície das fibras de sisal, aumentando sua adesão à matriz de borracha. $\mathrm{O}$ tamanho crítico de fibras, determinado para reforço nesta matriz nitrílica, foi de $6 \mathrm{~mm}$, sendo que o teor crítico de fibras foi de 11 pcr para a matriz de borracha pura e de 5,5 pcr para a matriz combinada com carbonato de cálcio. Determinou-se que o teor ideal de carbonato é de $67 \mathrm{pcr}$. As análises térmicas (TG e DSC) mostraram que os compósitos são termicamente estáveis até a temperatura em torno de $300^{\circ} \mathrm{C}$. Os materiais obtidos possuem uma boa relação custo/benefício tornando promissora sua utilização. 


\begin{abstract}
The preparation of elastomeric composites resistent to oils and abrasion, with mechanical properties enhanced through incorporation of natural fibers by calendering processing, is a promissing approach that enlarge the technological applications for these materials, and allow their production in industrial scale. In this work, nitrile rubber with sisal fibers composites and nitrile rubber with calcium carbonate and sisal fibers composites were developed. The composites were processed on a two roll mixing mill, in optimized processing conditions. It was studied the influence of calcium carbonate amount, size and amount of sisal fibers, and alkali treatment of the fibers on the composite properties. The composites, with short fibers randomly distributed, were characterized by mechanical analysis, scanning electron microscopy, thermogravimetric analysis (TG) and differential scanning calorimetry (DSC). Mercerization treatment promoted the remotion of lignin and hemicelluloses from the sisal fibers surface, increasing the adhesion between the fiber and the rubber matrix. The critical size of sisal fibers to reinforce the nitrile matrix was 6 milimeters, and the fibers critical volume was 11 phr for the pure rubber matrix, and 5.5 phr for the matrix containing calcium carbonate. The ideal volume of calcium carbonate was $67 \mathrm{phr}$. The thermal analysis (TG and DSC) demonstrated that the composites are thermally stable up to $300^{\circ} \mathrm{C}$. The materials developed have a good cost/benefits relation making promising their utilisation.
\end{abstract}




\section{1 - INTRODUÇÃo}

Visto ser uma fonte renovável, reciclável, biodegradável e de baixo custo, o uso de recursos vegetais para a produção de compósitos poliméricos consiste numa alternativa de grande importância tecnológica. Para paises com forte economia agrícola como o Brasil, o uso de fibras naturais como fonte de matéria prima para a indústria de polímeros reforçados, é uma forma importante de ampliar as possibilidades de explorar suas fontes de matérias primas naturais. A Empresa Brasileira de Pesquisa Agropecuária (EMBRAPA) vem se preocupando tanto com a parte essencialmente agrícola destes produtos, com vários projetos voltados para o melhoramento das condições de cultivo e produtividade dos mesmos, como também em desenvolver projetos na área de tecnologia de materiais, devido à necessidade de estudos especificamente voltados para caracterizar, avaliar e desenvolver novas aplicações para o melhor aproveitamento de vegetais de grande importância social e econômica para o país. Além disso, o Brasil é sem dúvida um dos paises que possui a maior biomassa do mundo e a maior extensão territorial cultivável, potenciais estes, que devem ser melhor explorados. Ultimamente tem crescido o interesse pelo uso das fibras naturais em materiais elastoméricos, sobretudo em matrizes de borracha natural (NR) e borracha butadieno-estireno (SBR). Um dos interesses pelo uso de sisal nestes estudos é satisfazer à norma ISO 14000 , assim como outras normas de 
proteção ecológico-ambiental, que estão sendo instrumento de grande importância nesta área, para garantir a preservação do meio ambiente. Além deste aspecto, escolheu-se a fibra de sisal como tema de estudo para este projeto devido às suas características fisico-químicas, por ser um material renovável e biodegradável e principalmente devido à grande implicação sócio-econômica que esta cultura representa para o Brasil. $O$ objetivo deste trabalho foi realizar um estudo de compósitos de borracha nitrílica reforçados com fibra de sisal, moldados por calandragem, na presença e ausência de carbonato de cálcio, buscando a obtenção de materiais de baixo custo com melhor desempenho e o entendimento da correlação estrutura e propriedades dos mesmos, os quais possam concorrer com as fibras sintéticas em aplicações onde as solicitações térmica e mecânica não sejam tão exigentes. Foram estudados os efeitos do tratamento, tamanho e teor das fibras nas propriedades mecânicas, bem como a microestrutura destes compósitos. Em termos de tratamento das fibras foi feito lavagem com água; tratamento com solução detergente; tratamento com solução de hidróxido de sódio; e tratamento com solução acetona/água, de modo a investigar-se o efeito provocado pelos mesmos na superficie das fibras. A intenção foi encontrar um tratamento que removesse os extrativos da fibra, aumentando a possibilidade de adesão com a matriz de borracha. Em se tratando do tamanho de fibras foi investigado o efeito de quatro tamanhos (3 $\mathrm{mm}, 6 \mathrm{~mm}, 10 \mathrm{~mm}$ e $14 \mathrm{~mm}$ ) visando identificar o tamanho crítico de fibra capaz de conferir adesão e reforço mecânico à matriz do compósito. Em termos de teor de fibra, foi investigado o efeito provocado pela adição de teores de fibra na faixa de $0 \mathrm{a}$ 44\% em peso. Análises de estabilidade térmica por TG e DSC foram realizadas para auxiliar no entendimento da correlação estrutura e propriedades. 


\section{2- FUNDAMENTOS TEÓRICOS E REVISÃO BIBLIOGRÁFICA}

\section{1- Materiais Compósitos}

A palavra compósito deriva de composto, ou seja, qualquer coisa formada por partes ou constituintes diferentes [1]. Na escala atômica, algumas ligas metálicas e alguns materiais poliméricos também podem ser considerados materiais compósitos, uma vez que são formados por agrupamentos atômicos diferentes. $\mathrm{Na}$ escala de grão (entre aproximadamente $10^{-4}$ e $10^{-2} \mathrm{~cm}$ ), uma liga metálica, por exemplo, pode ser considerada um material compósito uma vez que seus constituintes são facilmente distinguíveis quando observados por microscopia óptica. $\mathrm{Na}$ escala da macroestrutura (cerca de $10^{-2} \mathrm{~cm}$ ou superior), um plástico reforçado com fibras de vidro, no qual as fibras de vidro são facilmente detectadas a olho nu, é também considerado um material compósito. Assim, pode-se compreender que a dificuldade em estabelecer uma definição para material compósito reside nas limitações dimensionais que há de se impor aos constituintes que formam o material. Em termos de engenharia, um material compósito é geralmente entendido como um material cujos constituintes se distinguem à escala da microestrutura (grão) ou, de preferência, à escala da macroestrutura. Tendo em vista estas considerações, uma definição adotada para o termo consiste em: "Um material compósito é formado por 
uma mistura ou combinação de dois ou mais micro ou macro constituintes que diferem na forma e/ou na composição química e que, na sua essência, são insolúveis uns nos outros" [1].

A importância dos compósitos em engenharia deriva do fato de que, ao combinar-se dois ou mais materiais diferentes, pode-se obter um material compósito cujas propriedades são superiores, ou melhores, em alguns aspectos, às propriedades de cada um dos componentes. Os materiais compósitos podem ser selecionados para dar combinações não usuais de propriedades não existentes em um único material, como resistência mecânica, tenacidade, peso, dureza, condutividade, resistência à corrosão, desempenho em altas temperaturas, dentre outras [1, 2].

A maioria dos materiais compósitos consiste numa mistura de um material de reforço ou de enchimento, devidamente selecionado, com um material compatível que serve de ligante (ou matriz), sendo que seus componentes podem ser fisicamente identificados pelas interfaces que os separam. Baseado nas formas dos materiais, os compósitos podem ser classificados em três categorias: fibroso (formado por fibras no seio de uma matriz), particulado (formado por partículas no seio de uma matriz) ou laminado (formado por camadas alternadas entre o reforço e a matriz). Os compósitos particulados apresentam propriedades isotrópicas se suas partículas de reforço estiverem uniformemente distribuídas; os compósitos fibrosos podem ser isotrópicos ou anisotrópicos; e os compósitos laminados sempre apresentam comportamento anisotrópico [2].

\subsection{1- Materiais Compósitos Fibrosos}

A maioria dos compósitos reforçados com fibra apresenta melhorias na 
resistência mecânica, resistência à fadiga, tenacidade, e na razão resistência/peso devido à incorporação de fibras com alta resistência, dentro de uma matriz mais macia e dúctil. $\mathrm{O}$ material da matriz transmite a força às fibras, as quais suportam a maior parte da força aplicada. A resistência do compósito pode ser alta tanto à temperatura ambiente quanto em temperaturas elevadas [2].

Muitos fatores devem ser considerados quando do desenvolvimento de um material compósito, incluindo o comprimento, razão de aspecto (comprimento/diâmetro - 1/d), orientação, quantidade, e propriedades das fibras; as propriedades da matriz; e a ligação entre as fibras e a matriz [2].

Razão de aspecto (1/d): A resistência de um compósito aumenta quando a razão de aspecto é maior, o qual deve estar acima de um valor crítico para que a fibra alcance máxima deformação antes de ocorrer a falha no compósito. As fibras geralmente fraturam devido a imperfeições em suas superfícies. Tomando-se fibras com diâmetro tão pequeno quanto possível faz com que a mesma tenha uma pequena área superficial e, conseqüentemente, menor é a probabilidade de presença de falhas que podem se propagar durante o processamento ou quando submetida a alguma carga. Outra opção para aumentar a razão de aspecto é utilizar fibras de maior comprimento [2].

Orientação da fibra: A orientação da fibra tem uma influência significativa nas propriedades mecânicas do compósito, de modo que tais fibras de reforço podem ser introduzidas na matriz em diferentes orientações. Fibras curtas, randomicamente orientadas têm uma pequena razão de aspecto, sendo facilmente introduzidas na matriz e conferindo um comportamento relativamente isotrópico ao compósito. 
Arranjos unidirecionais de fibras longas produzem propriedades anisotrópicas, com particular boa resistência e rigidez paralela às fibras, ou seja, o valor de tensão é máximo ao longo da orientação do eixo da fibra. No entanto, orientações unidirecionais levam a propriedades pobres, se a carga é perpendicular ao sentido das fibras.

Quantidade: É esperado que o aumento na fração volumétrica das fibras aumente a resistência do compósito. No entanto, a fração de volume máxima que se pode empregar é, teoricamente, de cerca de $80 \%$, a partir do qual as fibras não podem mais ser completamente envolvidas pela matriz [2]. Outros fatores, como técnicas e condições de processamento têm também influência significativa nas propriedades mecânicas dos compósitos reforçados com fibras, particularmente compósitos termoplásticos em que a quebra da fibra devido ao tipo de processamento é um fenômeno comumente observado [3-4].

Propriedades das Fibras: Na maioria dos compósitos reforçados com fibras, as fibras são fortes, rígidas e leves. Se o compósito destina-se ao uso em elevadas temperaturas, a fibra também deve ter um alto ponto de fusão. A resistência à tração específica $(\sigma / \rho)$ e módulo específico $(E / \rho)$ da fibra são características importantes a serem consideradas. $(\sigma=$ resistência à tração; $\rho=$ densidade $\mathrm{e} E=$ módulo elástico).

Propriedades da Matriz: A matriz suporta as fibras e as mantém em suas posições próprias, transfere a carga às fibras fortes, protege as fibras contra danos durante o processo de manufatura e uso do compósito, e previne fraturas na fibra a partir de propagações no interior do compósito. A matriz normalmente fornece o 
maior controle sobre as propriedades elétricas, comportamento químico, e o uso dos compósitos em temperaturas elevadas.

Ligação e Falha entre a fibra e a matriz: Particularmente em compósitos de matrizes metálica e polimérica, uma boa ligação deve ser obtida entre os vários constituintes. As fibras devem estar firmemente ligadas ao material da matriz para que a solicitação de carga seja transmitida da matriz às fibras. Em adição, as fibras podem escapar da matriz durante aplicação da carga, reduzindo a resistência à tração e a resistência à fratura do compósito, caso a ligação seja pobre.

\subsection{2- Materiais Compósitos Particulados}

Os verdadeiros compósitos particulados contêm grandes quantidades de partículas grossas que efetivamente não bloqueiam deslizamentos que venham a ocorrer no compósito. Os compósitos particulados são projetados mais com o intuito de se produzir combinações não usuais de propriedades, do que melhorar a resistência mecânica dos mesmos [2].

Muitos polímeros de engenharia que contêm cargas são compósitos particulados. Um exemplo clássico é o uso de negro de fumo em borrachas vulcanizadas. O negro de fumo consiste em esferóides muito finas de carbono na faixa de 5 a 500 nanômetros de diâmetro, que além de melhorar a resistência mecânica, tenacidade, dureza, melhora também a resistência às intempéries, e a estabilidade térmica [2].

Enchimentos como o carbonato de cálcio, esferas de vidro sólidas, e várias argilas conferem propriedades diferentes aos compósitos, em relação àquelas 
proporcionadas por cargas como o negro de fumo ou sílica. Normalmente, aqueles são adicionados de modo que uma menor quantidade do polímero (componente mais caro) seja requerido. Tais enchimentos podem enrijecer o polímero, aumentar a dureza e a resistência às intempéries, aumentar a condutividade térmica, ou melhorar a resistência ao deslizamento; no entanto, a resistência mecânica e a ductilidade normalmente diminuem [2].

No presente trabalho estudou-se compósitos fibrosos e particulados, sendo o componente fibroso e o particulado investigados separadamente e em associação. $\mathrm{O}$ componente fibroso empregado foi fibra de sisal; o componente particulado foi carbonato de cálcio; e a matriz consistiu de material elastomérico (borracha nitrílica).

\section{2 - Sisal}

\subsection{1 - O Sisal no Cenário Nacional}

Nos últimos anos, têm-se multiplicado as pesquisas sobre a utilização de fibras naturais em materiais compósitos visando novos produtos ou a substituição das fibras sintéticas em produtos já existentes [5, 6]. Estas pesquisas têm como objetivo o desenvolvimento de tratamentos físicos e/ou químicos nas fibras vegetais para sua utilização em indústrias como a da construção civil, automobilística e aeronáutica [7, 8].

As fibras vegetais apresentam vantagens como baixa densidade; baixo consumo de energia na produção; baixo custo e baixa abrasividade nos equipamentos de processamento de polímeros $[9,10]$. As vantagens das fibras vegetais sobre as sintéticas incluem também aspectos ecológicos, em razão da melhor 
biodegradabilidade da fibra natural, além do fator socioeconômico, relacionado ao fato do Brasil ser um grande produtor de fibras vegetais, associado à questão social das regiões produtoras [6].

Entre as fibras vegetais produzidas no Brasil, as fibras de sisal se destacam pelas suas características físico-químicas e propriedades mecânicas. Esta fibra está entre as fibras vegetais mais utilizadas mundialmente. Quase 4,5 milhões de toneladas de fibra de sisal são produzidas anualmente no mundo [11]. O Brasil é o maior produtor e exportador mundial de fibras de sisal e sisal manufaturado. Em segundo lugar está o Quênia seguido pela Tanzânia. Aproximadamente $70 \%$ do sisal brasileiro beneficiado destinam-se aos mercados europeu e asiático, sendo $50 \%$ desse volume para Portugal, que dispõe de grande parque manufatureiro de fibras. Já o sisal manufaturado tem como principais importadores os Estados Unidos (86\%) e Canadá (5\%), além de outros dezessete paises em pequenas proporções. Em 1997, a produção nacional de fibras de sisal alcançou 135 mil toneladas, destas, 113 mil foram exportadas, sendo $26 \%$ de fibras e $74 \%$ de manufaturados, gerando divisas na ordem de 102 milhões de dólares [12]. Para o Brasil esta cultura é de extrema importância socioeconômica por ser economicamente viável na região semi-árida do Nordeste, geralmente onde as condições de clima e solo são pouco favoráveis ou de escassas alternativas para a exploração de outras culturas que ofereçam resultados econômicos satisfatórios $[6,13]$.

A cultura do sisal movimenta cerca de um milhão de trabalhadores, que dependem desta cultura como fonte de renda. $\mathrm{O}$ estado da Bahia responde por $\mathbf{8 6 , 7 \%}$ da produção, com uma área de cultivo de 147 mil ha., e a Paraíba por $11,1 \%$ com 100 mil ha. Os 2,2\% restantes estão distribuídos entre os Estados do Ceará, Rio Grande do Norte e Pernambuco $[12,14]$. Na Paraíba o sisal se constitui no principal produto 
da pauta de exportação e, na Bahia, o quinto produto de importância [http:www.cnpa.embrapa.br/sisal/sisalinfo.html- Agosto/2001].

\subsection{2 - Ciclo, Corte e Beneficiamento das Folhas de Sisal}

O sisal é originário da península do Yucatã, no México. Em 1834 as primeiras mudas foram levadas para o sul da Flórida (EUA) e a partir de 1892 começaram a ser cultivadas na África. De todas as variedades cultivadas atualmente, as que mais se destacam comercialmente são a Agave sisalana Perrine, popularmente conhecida como sisal e a Agave fourcroydes Lamaire, conhecida como henequém [15].

O primeiro corte da Agave sisalana é realizado com aproximadamente 36 meses após a data do plantio, sendo colhidas de 50 a 70 folhas. Nos cortes subseqüentes, executados anualmente, podem ser retiradas cerca de 30 folhas e usualmente são deixadas de 7 a 9 folhas na planta. $O$ ciclo produtivo da planta dura em média de 8 a 10 anos, com produção média de 180 a 250 folhas/ciclo [http:www.cnpa.embrapa.br/sisal/sisalcolheita.html - novembro/2001]. As fibras são extraídas das folhas, que possuem de 8 a $10 \mathrm{~cm}$ de largura e de 150 a $200 \mathrm{~cm}$ de comprimento. Cada folha contém de 1000 a 1200 fibras. As folhas são compostas por $4 \%$ de fibra, $0,75 \%$ de cutícula, $8 \%$ de matérias secas e $87,25 \%$ de água $[16,17]$. Os resíduos de beneficiamento, obtidos no processamento da fibra são aproveitados na produção de hecogenina para a indústria farmacêutica, como ração animal, na produção de carvão vegetal por briquetagem e na produção de etanol e furfural [http://www.gestaoct.org.br/eletrônico/jornais/numero100.htm - janeiro/2003]. O beneficiamento compreende as etapas de desfibramento, lavagem, secagem, 
batimento, prensagem e enfardamento [18].

O transporte das folhas cortadas para o local de desfibramento geralmente é feito por asininos (jumentos). $O$ desfibramento do sisal é a operação mais complexa e de maior custo. As folhas devem ser desfibradas dentro de 24 horas, pois a partir dai elas começam a murchar. A máquina, denominada "Motor de agave" ou "Máquina Paraibana" é, até hoje, a principal desfibradora dos sisais no Brasil, embora apresente baixa capacidade operacional (em torno de 150 a $200 \mathrm{Kg}$ de fibra seca em um turno de 10 horas/dia), produza grande desperdício de fibras (em média 20 a $30 \%$ da fibra contida na folha), além de necessitar de um número elevado de pessoas. Após o desfibramento, a fibra obtida é transportada por meio de padiola ou no dorso de animais, para tanques com água limpa, onde é imersa por um período de 8 a 12 horas (geralmente à noite), para limpeza dos resíduos da mucilagem péctica e da seiva clorofilica, agregados à fibra. Em seguida as fibras são levadas para secagem e clareamento, ao sol, em varais ou estaleiros por um período de 8 a 10 horas [http:www.cnpa.embrapa.br/sisal/sisalcolheita.html - novembro/2001].

No nordeste, grande parte dos produtores de sisal comercializa o produto na forma bruta, sem realizar a etapa de batimento ou escovamento. Esta operação é realizada em máquinas denominadas "batedeiras" e, geralmente se perde de 8 a $10 \%$ da massa original da fibra pela eliminação dos resíduos parenquimatosos, em forma de pó e fibras curtas, denominadas bucha. O pó pode ser aproveitado como adubo orgânico e ração animal. A bucha pode ser utilizada para obtenção de celulose, estofados e como componentes de polímeros para aplicações em materiais para uso doméstico e até mesmo para a indústria automobilística. Após o batimento, as fibras são selecionadas por tipo ou classe. O Ministério da Agricultura estabeleceu a seguinte classificação para as fibras de sisal com o objetivo de homogeneizar a sua 
comercialização: Extra longa para fibras acima de $111 \mathrm{~cm}$; Longa para fibras de 91 a $110 \mathrm{~cm}$; Média para fibras de 71 a $90 \mathrm{~cm}$; Curta para fibras de 60 a $70 \mathrm{~cm}$; e é $\begin{array}{llllllll}\text { considerado } & \text { refugo } & \text { a } & \text { fibra menor } & \text { que } & 60 & \mathrm{~cm}\end{array}$ [http:www.cnpa.embrapa.br/sisal/sisalcolheita.html - novembro/2001], embora possam estas últimas, ser perfeitamente aproveitadas para reforço em diversos materiais compósitos, representando assim um benefício econômico. Depois de serem escovadas e classificadas, as fibras são enfardadas para o transporte até a indústria.

\subsection{3 - Composição Química das Fibras de Sisal}

As fibras naturais vegetais podem diferir consideravelmente em suas aparências físicas, mas elas possuem, no entanto, muitas similaridades que as identificam como uma família. As características das fibras dependem das propriedades dos constituintes individuais, da estrutura fibrilar e da matriz lamelar [3].

As propriedades das fibras celulósicas dependem principalmente da natureza da planta; localidade na qual ela se desenvolve; idade e método de extração usado [19]. As fibras de sisal são constituídas de fibrilas ou fibras elementares que têm de 1,5 a 4 mm de comprimento, diâmetro de 10 a $30 \mu \mathrm{m}$, e a espessura da parede celular varia de 6 a $9 \mu \mathrm{m}$ [20]. A composição química varia de planta para planta e mesmo nas várias partes de uma mesma planta. Em conseqüência disto, tem sido observado também que as propriedades de resistência mecânica da fibra de sisal não são uniformes ao longo do comprimento da fibra. A parte basal apresenta baixo módulo e baixa resistência ao tensionamento; a região central torna-se mais forte, e a parte 
apical apresenta resistência moderada [16].

Quimicamente, as fibras vegetais consistem de celulose, hemicelulose, lignina, pectina e uma pequena quantidade de ceras e gorduras [3]. Bledzki \& Gassan [21], Joseph e colaboradores [22], Varghese e colaboradores [23], Silva e colaboradores [24], dentre outros trabalhos da literatura, apresentam a composição química encontrada para fibras de sisal empregadas em seus experimentos, conforme ilustrado na Tabela 1.

Tabela I: Composição química da fibra de sisal apresentada por diferentes pesquisadores.

\begin{tabular}{|l|c|c|c|c|}
\hline Componente & Bledzki [21] & Joseph [22] & Varghese [23] & Silva [24] \\
\hline Celulose & 65,8 & $66-72$ & 78 & $65-70$ \\
\hline Hemicelulose & 12,0 & 12 & 10 & $10-13$ \\
\hline Pectina & 0,8 & & & \\
\hline Lignina & 9,9 & $10-14$ & 8 & $11-16$ \\
\hline Ceras & 0,3 & & 2 & \\
\hline Inorgânicos (cinzas) & & & 1 & $1-3$ \\
\hline Extrativos & & & & $14-16$ \\
\hline Solúveis em água & 1,2 & & & \\
\hline Umidade & 10,0 & 10 & & $8-12$ \\
\hline
\end{tabular}

Celulose: A celulose consiste no principal componente da parede celular dos vegetais, compreendendo $50 \%$ de toda a biomassa vegetal [25]. É um polissacarídeo amplamente encontrado na natureza, sendo de função estrutural. A celulose é um homopolímero linear derivado da glucose, formado por unidades moleculares $\beta$-Dglicopiranose, as quais se unem através de ligações glicosídicas $\beta(1-4)$, resultando em um polímero de alta massa molar, cujo valor depende da fonte de celulose, e os resultados obtidos são influenciados pelo tratamento que ela recebe e pelo método 
utilizado para determinação da massa molar [26]. A unidade repetitiva é chamada de celobiose, estando representada na Figura 1. Mesmo uma amostra uniforme apresenta cadeias moleculares com uma pequena diferença nos valores do grau de polimerização, razão pela qual esse número é considerado como grau de polimerização médio para a celulose. Celulose de madeira, por exemplo, tem um grau de polimerização médio entre $9.000-10.000$, que corresponde a uma cadeia de aproximadamente $5 \mu \mathrm{m}$ de comprimento.

A união glicosídica atua como grupo funcional, e junto com os grupos hidroxilas determinam as propriedades químicas da celulose. Todas as reações importantes ocorrem nestas posições [25, 27].

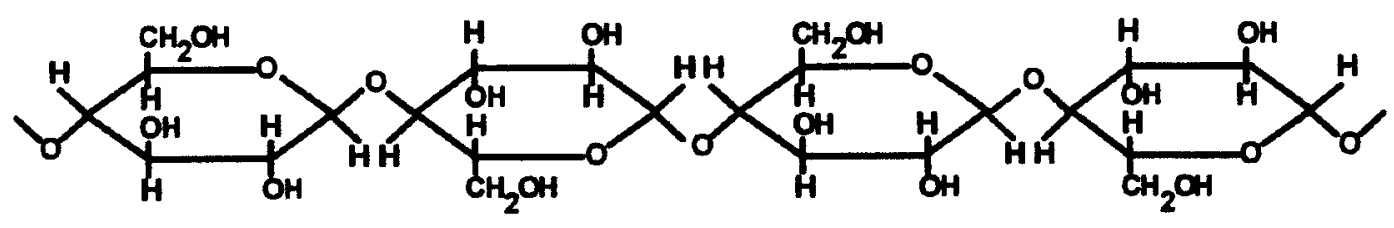

Unidade de Celoblose

Figura 1 - Estrutura molecular da celulose [27].

A celulose tem alta tendência a formar ligações de hidrogênio intra e intermoleculares. As interações intramoleculares são responsáveis pela rigidez das cadeias unitárias, e as intermoleculares pela formação da fibra vegetal, isto é, as moléculas de celulose se alinham formando as microfibrilas, as quais formam as fibrilas que, por sua vez, se ordenam para formar as sucessivas paredes celulares da fibra. 
As cadeias unitárias unem-se formando feixes com regiões cristalinas altamente organizadas, que se encontram intercaladas com regiões amorfas. Em função desta estrutura fibrilar e das ligações de hidrogênio, a celulose apresenta resistência à tração, ao alongamento e solvatação (absorção de solventes), sendo que a resistência à tração na região cristalina é superior à da região amorfa, onde a fibra tem maior flexibilidade [27].

Hemicelulose: As hemiceluloses, ou polioses, são polissacarídeos constituídos de uma mistura de diferentes unidades de açúcares, formando cadeias moleculares curtas e ramificadas. Apresentando um grau de polimerização ao redor de 200, possuem uma massa molar muito menor que as macromoléculas de celulose [4]. As unidades monossacarídeas que compõem as polioses ou hemicelulose podem ser subdivididas em grupos tais como pentoses, hexoses, ácidos urônicos e deoxihexoses, cujas estruturas estão apresentadas na Figura 2. Estes grupos se dividem em polissacarídeos não modificados que são alguns compostos de unidades de pentose (xilose, arabinose) e outras hexoses (manose, galactose, glicose) e polissacarídeos modificados as quais contém uma ou mais unidades de ácidos urônicos. As cadeias monoméricas citadas possuem relativamente baixa massa molar e podem ser extraídas das plantas, o que é feito mais freqüentemente com soluções alcalinas [27]. 


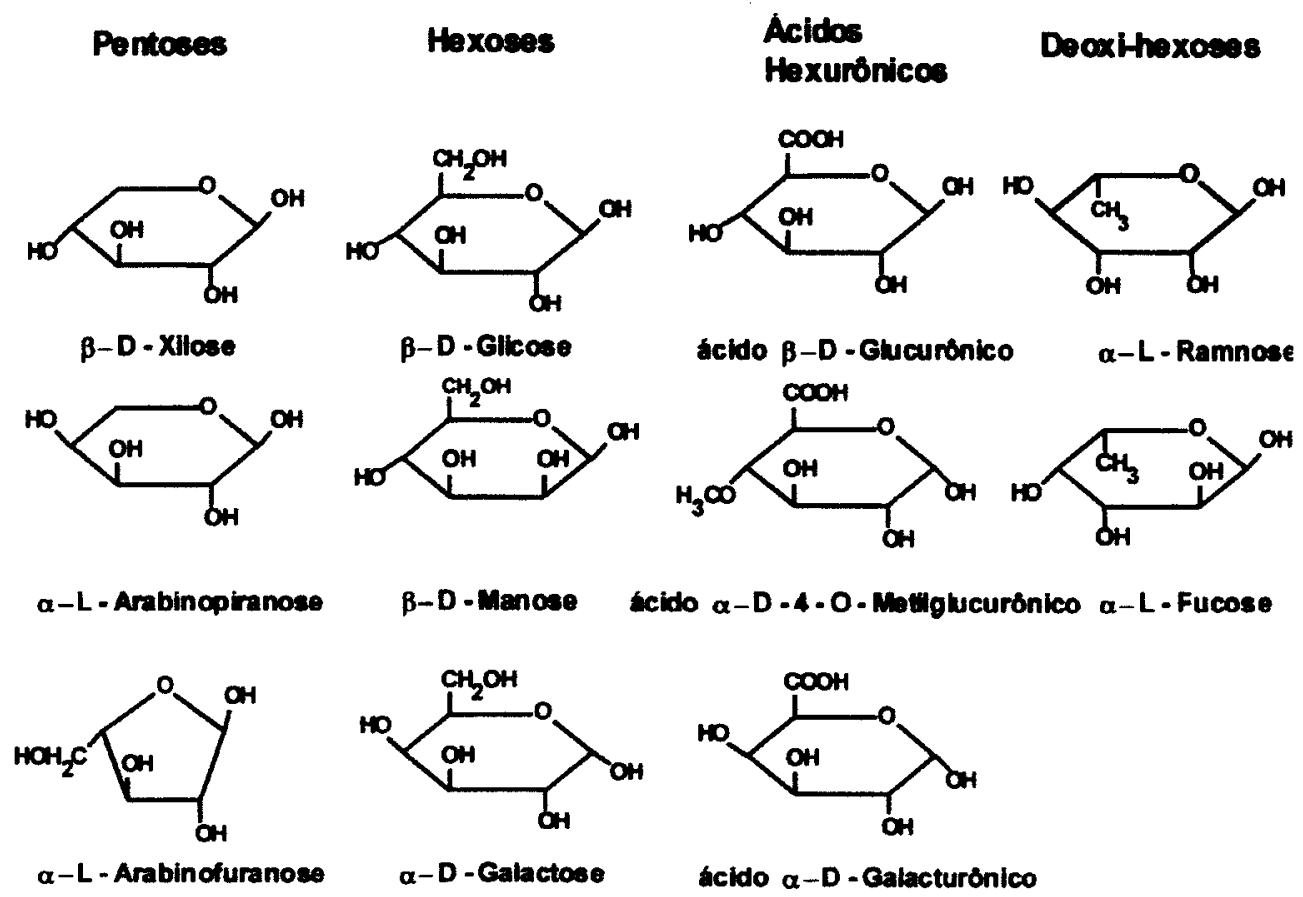

Figura 2 - Fórmula dos açúcares constituintes das polioses [27].

Lignina: A lignina é o segundo componente em maior abundância nas plantas vasculares. Consiste num composto macromolecular ramificado que possui função estrutural, oferecendo rigidez à estrutura celulósica das células e tecidos, e também agindo como proteção à degradação das fibras vegetais.

Sua estrutura consiste de um sistema aromático composto de unidades fenil propânicas, cujos precursores podem ser o álcool p-cumarílico, álcool coniferilico ou o álcool sinapílico, os quais estão apresentados na Figura 3.

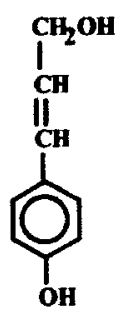

I

álcool p-cumarilico

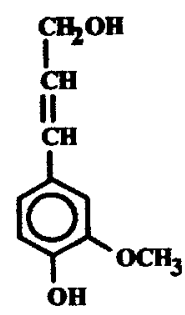

II

alcool coniforilico<smiles>COc1cc(C=CCO)cc(OC)c1O</smiles>

III Alcool sinapilico

Figura 3 - Principais precursores da lignina [27]. 
Sob o aspecto morfológico, a lignina é uma substância amorfa, formada pela polimerização desidrogenativa das moléculas destes álcoois precursores; localiza-se na parede celular e na região da lamela média das plantas. É difícil estabelecer corretamente o grau de polimerização, devido às rupturas que ocorrem durante sua extração. A presença de diferentes unidades precursoras e o elevado número de combinações possíveis entre as unidades faz com que a estrutura da macromolécula de lignina seja bem mais complexa que as apresentadas pela celulose e hemiceluloses [27]. Na Figura 4 pode ser visto um modelo estrutural da lignina apresentado por $\operatorname{Nimz}[28]$.

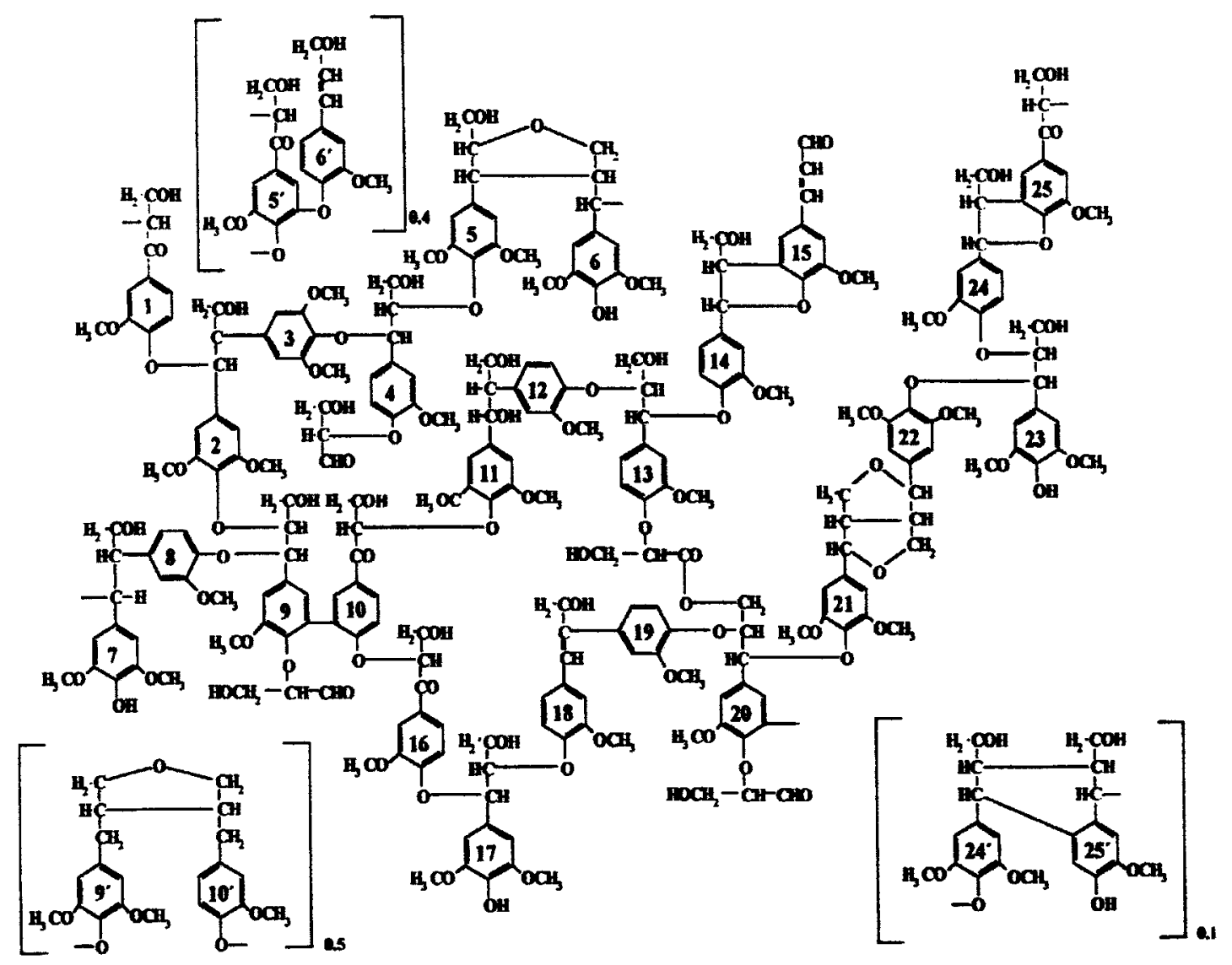

Figura 4 - Modelo estrutural de lignina de folhosa (Fagus sylvatica) apresentada por Nimz [28]. 
Extrativos: Os extrativos incluem uma diversidade de compostos, os quais podem ser extraídos com solventes polares e apolares. Eles podem ser classificados em vários grupos, de acordo com suas propriedades químicas e características estruturais. Para a fibra de sisal, a porção dos extrativos vegetais solúvel em solventes orgânicos está na faixa de 14-16\%.

Uma parte dos extrativos é classificada como resina, referindo-se ao seu estado físico, e não obviamente à caracterização de um composto químico. Conceitua-se resina como sendo uma secreção viscosa que exsuda do caule e de outros órgãos de determinadas plantas. Compostos como terpenos, estilbenzenos, flavonóides e outros compostos aromáticos podem ser componentes da resina. Além destes, outros compostos orgânicos como gorduras, ceras, ácidos graxos, álcoois, esteróides e hidrocarbonetos de elevada massa molar podem estar presentes nos extrativos [26].

Componentes inorgânicos: Os componentes inorgânicos (cinzas) estão presentes nos vegetais em teores compreendidos entre $1-3 \%$, e são constituídos de oxalatos, carbonatos e silicatos de cálcio, de potássio e de magnésio. Além destes, pode-se encontrar um grande número de elementos em quantidades muito pequenas como alumínio, ferro, zinco, cobre, titânio, chumbo, níquel, cobalto e outros [27].

\subsection{4 - O Sisal em Materiais Compósitos}

Um dos problemas associados ao uso de fibras naturais como reforços em matrizes termoplásticas, de modo a obter-se materiais compósitos com propriedades 
mecânicas e estabilidade dimensional melhoradas, são a pobre molhabilidade e fraca ligação interfacial com o polímero, devido à pobre compatibilidade entre as fibras celulósicas hidrofilicas com os termoplásticos hidrofóbicos [5].

Métodos físicos e químicos podem ser usados para modificar as fibras de reforço, otimizando a interface fibra-matriz [21]. Encontra-se na literatura diversos estudos onde as propriedades físico-químicas e a modificação da superfície das fibras são investigadas, objetivando sua utilização em materiais compósitos [15-16, 29-37].

Mukherjee \& Satyanarayana [38] estudaram as propriedades mecânicas das fibras de sisal através de ensaios de tensão-deformação, variando a velocidade dos ensaios, o diâmetro e o comprimento das fibras. Foi observado que a variação no diâmetro das fibras não influenciou de forma significativa nas suas propriedades mecânicas; no entanto, observaram que o comprimento das fibras e a velocidade de deslocamento entre garras influenciam nas propriedades mecânicas. Em materiais compósitos, as fibras de sisal já foram avaliadas como reforço em diversas matrizes, tais como polietileno [39-41], polipropileno [22, 42-43], poliestireno [44] e epóxi $[13,45-47]$.

Em diferentes estudos realizados com poliolefinas, Joseph e colaboradores [4849] encontraram que fibras de sisal com $6 \mathrm{~mm}$ de comprimento conferem ao polietileno maior módulo dinâmico. Verificaram ainda que quando orientadas, as fibras conferem resistência à tração e módulo superior a 2 vezes ao valor encontrado para uma distribuição randômica das fibras.

Os resultados obtidos nestes trabalhos demonstram que a utilização das fibras de sisal em materiais compósitos, além das vantagens que as fibras vegetais apresentam em relação às sintéticas (baixo custo, fontes renováveis, baixa abrasividade), é promissora devido ao desempenho mecânico obtido com as mesmas. Mostram ainda, 
que a utilização das fibras vegetais em diferentes matrizes, mesmo sem qualquer tratamento, leva à melhoria do desempenho de algumas propriedades dos compósitos. O tratamento fisico e/ou químico aumenta significativamente a possibilidade de utilização deste material. No entanto, para a utilização destes compósitos, mesmo na área não estrutural, propriedades como a durabilidade do material, homogeneidade da produção e condições adequadas de processamento precisam ser otimizados . O interesse no desenvolvimento de um tratamento químico eficiente, economicamente viável e que proporcione uma boa adesão fibra/matriz tem sido alvo de pesquisa de vários grupos $[3,15]$.

\section{3 - Borracha Nitrílica}

\subsection{1 - Histórico da Borracha Natural e Sintética}

A arte do desenvolvimento de produtos úteis a partir de materiais elastoméricos de origem natural ou sintética é descrita genericamente pelo termo "Compostos de borracha".

O aparecimento da borracha natural ocorreu no século XV, quando Colombo relatou ter visto nas praias do Novo Mundo nativos jogando com uma bola que realmente pulava e ricocheteava. A árvore Hevea brasiliensis é a principal fonte da borracha natural e a sua existência na bacia do Amazonas foi relatada pela primeira vez pelo acadêmico francês Charles de la Condamine, em 1736. Os usos da borracha natural eram limitados devido a sua deterioração na presença de oxigênio. Felizmente, foram desenvolvidos produtos capazes de impedir a oxidação, e em 1924 
apareceu o primeiro antioxidante comercial, ao qual se seguiu uma série deles [50].

A história da borracha sintética pode ser traçada desde 1826, quando Faraday conseguiu estabelecer a fórmula empírica da borracha natural, ou seja, $\mathrm{C}_{5} \mathrm{H}_{8}$. Embora a estrutura exata da borracha natural tenha sido alvo de muitas controvérsias, o fato é que o trabalho de Faraday foi de inestimável valia, auxiliando todos os cientistas que a partir daquela data de uma forma ou de outra tentaram a produção da borracha sintética tendo em vista obter um produto com propriedades semelhantes ou possivelmente melhores que as da borracha natural. Isto foi seguido pelo trabalho de Bouchardat, que em 1879 obteve uma massa semelhante à borracha natural por aquecimento do isopreno com ácido clorídrico em tubo selado. $\mathrm{O}$ fato de se poder

polimerizar o isopreno despertou a atenção do químico inglês Tilden, já em 1884 . Mas não foi ele, senão Euder, quem conseguiu, em 1897, obter sinteticamente o isopreno e desta forma iniciar e completar a síntese da borracha. A primeira produção comercial da borracha sintética se deve aos alemães durante a Primeira Guerra Mundial. Eles produziram metilisopreno em quantidades limitadas, e, além disso, com péssimas qualidades mas que, entretanto serviram aos seus propósitos de emergência. Após a guerra, com o reaparecimento no mercado da borracha natural, a produção de borracha sintética foi abandonada, mas os trabalhos de investigação continuaram e, em 1933 Tschunkur e Bock descobriram a borracha nitrílica [50].

\subsection{2 - Propriedades da Borracha Nitrílica e suas aplicações em compósitos}

As borrachas preparadas por copolimerização de butadieno e acrilonitrila são conhecidas por vários nomes genéricos, como Buna N, NBR ou Borracha Nitrílica; sendo este último o mais conhecido popularmente. $O$ teor de acrilonitrila 
normalmente varia na faixa de 15 a $50 \%$, sendo que a propriedade mais significativa destas borrachas é sua excelente resistência aos óleos e aos solventes aromáticos, o que é controlado quase que exclusivamente pelo teor de acrilonitrila. Quanto mais alto esse valor, maior a resistência aos óleos [51-52].

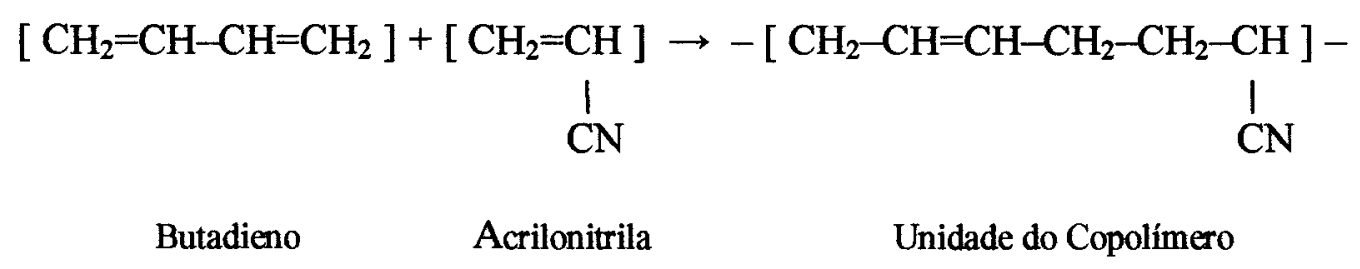

A presença dos grupos nitrílicos aumenta a polaridade das cadeias e o número de ligações de hidrogênio entre cadeias adjacentes [1], sendo responsáveis por sua alta resistência aos óleos e solventes não polares [53]. Em adição, exibem ainda excelente resistência à abrasão e boas características de assentamento à compressão. Devido a sua versatilidade, são usadas em aplicações que requerem resistência a combustiveis, ao aquecimento, à água, e permeabilidade aos gases. São de natureza polar, o que thes confere usos como adesivos [50-51]. Na Tabela II encontram-se algumas propriedades fisicas das borrachas nitrílicas [50].

Os polímeros nitrílicos são amorfos, não cristalinos, e necessitam de cargas de reforço para que suas propriedades sejam otimizadas [51]. O sistema borrachareforço, no caso especial borracha-fibras, pode ser considerado um compósito que combina a resistência e rigidez das fibras curtas com o comportamento elástico da borracha [54].

O desempenho de compósitos reforçados com fibras, além das características da fibra vegetal, também depende da compatibilização entre a fibra e a borracha, expressa fortemente pela polaridade das mesmas. Um dos parâmetros mais 
importantes em materiais compósitos é a interface entre o reforço e a matriz. A interface é a região onde ocorre o contato entre os componentes do compósito. A região interfacial é a principal responsável pela transferência da solicitação mecânica da matriz para o reforço. A adesão inadequada entre as fases envolvidas na interface poderá provocar o início de falhas, comprometendo o desempenho do compósito. Portanto, além das propriedades individuais de cada componente do compósito, a interface deve ser a mais adequada possivel para otimizar a combinação das propriedades envolvidas [3].

Tabela II: Propriedades Físicas das Borrachas Nitrílicas [50].

\begin{tabular}{|c|c|c|}
\hline \multicolumn{2}{|c|}{ Propriedade } & Desempenho \\
\hline \multicolumn{2}{|l|}{ Dureza (Shore A) } & $40-95$ \\
\hline \multicolumn{2}{|l|}{ Peso específico $\left(\mathrm{g} / \mathrm{cm}^{3}\right)$} & $0,98-1,00$ \\
\hline \multicolumn{2}{|c|}{ Propriedades Vulcanizadoras } & Excelentes \\
\hline \multicolumn{2}{|c|}{ Adesão aos metais } & Excelente \\
\hline \multicolumn{2}{|l|}{ Adesão a tecidos } & Boa \\
\hline \multicolumn{2}{|l|}{ Resistência ao rasgamento } & Regular \\
\hline \multicolumn{2}{|l|}{ Resistência à abrasão } & Excelente \\
\hline \multicolumn{2}{|l|}{ Ajuste à compressão } & Bom \\
\hline \multirow{2}{*}{ Ricocheteamento } & frio & Bom \\
\hline & q quente & Bom \\
\hline \multicolumn{2}{|l|}{ Resistência dielétrica } & Pobre \\
\hline \multicolumn{2}{|l|}{ Isolamento elétrico } & Pobre \\
\hline \multicolumn{2}{|l|}{ Permeabilidade aos gases } & Boa \\
\hline \multirow{2}{*}{ Resistência aos ácidos } & Diluídos & Boa \\
\hline & Concentrados & Boa \\
\hline \multirow{3}{*}{ Resistência aos solventes } & Hidrocarbonetos alifáticos & Excelente \\
\hline & Hidrocarbonetos aromáticos & Boa \\
\hline & Oxigenados & Pobre \\
\hline
\end{tabular}

Encontra-se na literatura compostos de borracha nitrílica com outros tipos de borracha e com outros materiais poliméricos, como por exemplo, polietileno, 
polipropileno e PVC [53-57].

Em termos de aplicação de fibras de sisal como reforço de borrachas, encontram-se na literatura estudos em que a matriz é de borracha natural, sempre envolvendo processo de vulcanização [23, 58-60]. Num destes estudos, Geethamma e colaboradores [61] avaliaram o efeito do comprimento da fibra de sisal mercerizada nas características de vulcanização e nas propriedades mecânicas do compósito. Encontraram que as propriedades mecânicas na direção longitudinal são superiores aos da direção transversal, e que o tamanho ótimo de fibra é de $10 \mathrm{~mm}$.

Por outro lado, Kumar \& Thomas [62] avaliando o uso de fibras de sisal em compósitos de borracha SBR, encontraram que as melhores propriedades mecânicas foram obtidas quando o tamanho de fibra foi de $6 \mathrm{~mm}$.

As propriedades finais dos compósitos reforçados com fibras de sisal justificam o atual interesse em um tratamento que as tornem economicamente viáveis $[41,63]$. Os estudos realizados para a caracterização e aplicação destas fibras como reforço mostram que para torná-las competitivas é necessário melhorar a adesão fibra/matriz $[6,7,10,47]$. Isto pode ser obtido através de diferentes métodos como a modificação da fibra $[7,10,49,64]$, o uso de agentes de compatibilização [61, 6567], o desenvolvimento de um processamento adequado [7, 62], ou da combinação de mais de um destes métodos.

\subsection{3 - Processamento por Calandragem}

A calandragem é o processo pelo qual se fabrica uma chapa contínua (ou filme laminado) passando o material amolecido pelo calor, entre dois ou mais cilindros. As calandras foram originariamente projetadas para o processamento da 
borracha, mas agora são amplamente usadas para a produção de laminados termoplásticos, especialmente de PVC flexível, e para a preparação de revestimentos sobre papel, tecidos, etc.

O processo de calandragem consiste na alimentação de uma massa entre dois cilindros, que a comprimem para a formação de um filme de espessura desejada, que passa em volta dos cilindros restantes da calandra. Da calandra, o filme emerge em forma contínua, naturalmente, mas pode ser cortado em chapas ou folhas logo a seguir. A espessura do filme é controlada pela abertura dos rolos finais da calandra. O aspecto da superfície do filme é determinado quase que exatamente pelo aspecto da superficie do último cilindro (brilhante, fosco ou texturizado). Após deixar a calandra, o filme laminado é esfriado, passando por rolos de resfriamento antes do enrolamento final.

A mistura que alimenta a calandra pode ser um simples polímero fundido, ou uma pré mistura de polímero com estabilizantes, plastificantes, etc. A massa passa por um misturador do tipo banbury; a seguir passa por um moinho de dois rolos onde é transformada em chapas com a finalidade de melhorar a mistura, passando depois à calandra para o trabalho final.

As calandras podem ser fabricadas com $2,3,4$ ou 5 cilindros ocos com previsão para aquecimento ou resfriamento a água ou vapor, e são caracterizadas pelo número e arranjo dos cilindros, isto é, em $\mathrm{I}, \mathrm{Z}$ ou $\mathrm{L}$ invertido. As mais comuns são de 4 rolos do tipo $\mathrm{L}$ invertido.

As calandras são máquinas que requerem controles adequados. Precisam de aparelhagem para obter temperaturas elevadas e estas temperaturas devem ser uniformes ao longo de cada cilindro. Por outro lado necessitam de pressões elevadas, mecânicas e pneumáticas, com tolerâncias reduzidas. A uniformidade de temperatura 
se obtém fazendo circular, pela parte oca dos cilindros, água em pressão ou vapor d'água distribuído por intermédio de orifícios concêntricos e circulando óleo quente em volta dos mancais, para evitar perdas de calor através das extremidades dos cilindros [50].

\section{4 - Carbonato de Cálcio}

O Carbonato de Cálcio pode ser do tipo natural ou sintético.

O termo "carbonato de cálcio precipitado" aplica-se a todos os compostos $\mathrm{CaCO}_{3}$ produzidos por meios químicos. O termo "precipitado" distingue estes tipos químicos sintéticos daqueles produzidos por tratamento mecânico dos calcáreos de ocorrência natural. Embora quimicamente sejam compostos predominantemente por carbonato de cálcio, os tipos precipitados diferem por apresentar tamanhos de partícula mais finos e uniformes, uma faixa de tamanho de particulas mais estreita, e por um maior grau de pureza química; diferenças estas que fazem do carbonato de cálcio precipitado um produto mais caro que o de ocorrência natural [68].

O Carbonato de Cálcio Mineral é o mais importante e abundante de todas as rochas sedimentares que são empregadas comercialmente. Possuem fórmula $\mathrm{CaCO}_{3}$, porém existe em sua composição uma pequena quantidade de $\mathrm{MgCO}_{3}$ (3\% no máximo) e possivelmente quantidades mínimas de outras impurezas como $\mathrm{SiO}_{2}$, $\mathrm{Al}_{2} \mathrm{O}_{3}, \mathrm{Fe}, \mathrm{P}$ e S. Os depósitos são normalmente de origem orgânica, iniciados com organismos marinhos. Através de processos de sedimentação, dissolução, e precipitação, grandes camadas destes minerais têm sido depositadas como sedimentos sobre a terra, nos rios, lagos e oceanos. Embora depositados

originalmente nos oceanos, eles estão agora expostos sobre a terra, devido às 
profundas mudanças na elevação entre a terra e o mar que têm ocorrido através do tempo geológico [68].

$\mathrm{Na}$ indústria da borracha existe uma tendência geral para substituir-se o negro de fumo por cargas minerais brancas. $\mathrm{O}$ fato de cargas brancas, como carbonato e silicato, serem não-tóxicos, constitui um outro argumento a favor de tal aplicação [69].

O carbonato de cálcio é freqüentemente usado como carga em produtos de borracha. $\mathrm{Na}$ verdade, excluindo-se os negros de fumo, o carbonato de cálcio consiste no segundo tipo de carga branca mais usada, perdendo apenas para o caolim. A razão para esta popularidade é que cargas bastante elevadas podem ser usadas junto às borrachas, com pequena perda de maciez, elongação, ou resiliência [69].

Como já mencionado, os elastômeros nitrílicos são amorfos e necessitam de cargas de reforço para otimização de suas propriedades [51]. Cargas minerais são usadas onde se requer cores diferentes de preto, ou onde compostos de baixo custo são necessários. As melhores cargas minerais, tais como sílica em seus diferentes tipos e alumina, são capazes de proporcionar excelentes propriedades de resistências mecânicas à borracha nitrílica, comparáveis aos melhores negros de fumo. No entanto, são típicas as deficiências conferidas quando se considera compressão e resiliência. Cargas minerais intermediárias, como carbonatos de cálcio e silicato de cálcio, são usadas onde um aumento de flexibilidade é necessário, com a manutenção de boa resistência à tração [51].

Poh e colaboradores [70] analisaram as diferenças de comportamento em diferentes blendas de borrachas quanto ao uso de negro de fumo, sílica e carbonato de cálcio. Constataram que o negro de fumo é a carga que propicia os maiores aumentos nas propriedades de resistência à tração e módulo; enquanto que a adição 
de carbonato de cálcio praticamente não alterou o módulo da blenda, mesmo em proporções de 40 pcr. No entanto, a adição de carbonato aumenta a elongação do compósito, enquanto que a sílica e negro de fumo reduzem-na.

Saad \& Younan [71] estudaram uma combinação de carbonato de cálcio com fibras curtas de nylon 6, como reforço para borracha natural. Determinaram que o compósito com 25 pcr de fibras, associado a 40 pcr de carbonato foi o que apresentou as melhores propriedades mecânicas e elétricas. 


\section{3- OBJETIVOS}

Este projeto visa o desenvolvimento de compósitos de borracha nitrílica reforçados com fibra de sisal. Investigou-se o efeito de reforço da fibra de sisal sobre a borracha pura e em combinação com carbonato de cálcio. Este estudo foi realizado com os seguintes objetivos:

- Avaliar o desempenho mecânico dos compósitos (1) borracha nitrílica /fibra de sisal; (2) borracha nitrílica/carbonato de cálcio e (3) borracha nitrílica /carbonato de cálcio/fibra de sisal.

- Otimizar o tamanho de fibras de sisal nos compósitos, correlacionando-o com as propriedades mecânicas.

- Avaliar a influência da modificação superficial da fibra na adesão fibramatriz, determinando o tratamento que confere as melhores propriedades mecânicas aos compósitos. Investigou-se o comportamento dos compósitos com fibras sem tratamento, fibras lavadas em água quente e mercerizadas.

- Otimizar o teor de fibras de sisal nos compósitos, correlacionando-o com as propriedades mecânicas.

- Estudar a estabilidade térmica dos compósitos através de análise termogravimétrica (TG) e calorimetria exploratória diferencial (DSC). 


\section{4 - EXPERIMENTAL}

\section{1 - Materiais}

\subsection{1 - Fibras de Sisal}

As Fibras de Sisal usadas foram da variedade Agave sisalana, provenientes de Campina Grande/PB. As amostras foram extraídas de plantas em seu segundo ano de colheita, possuiam $1,50 \mathrm{~m}$ de comprimento, $\mathrm{e}$ foram fornecidas pela Embrapa/CNPDIA.

\subsection{2 - Borracha Nitrílica}

A Borracha Nitrílica empregada corresponde a Nitriflex® N-206, a qual foi preparada com um teor de acrilonitrila de $45 \%$. O material é produzido pela Nitriflex S.A. e foi fornecido pela $3 \mathrm{M}$ do Brasil Ltda.

Massa específica: $0,98 \mathrm{~g} / \mathrm{cm}^{3}$.

Viscosidade Mooney: $50-70$ (ML 4' a $100^{\circ} \mathrm{C}$ ).

Temperatura de polimerização: a frio.

Solubilidade em MEK: mínimo de $98 \%$.

\subsection{3 - Carbonato de Cálcio}

O Carbonato de Cálcio utilizado corresponde à forma natural (calcita), 
micronizada, de elevada pureza, cujas partículas são revestidas por um silicato natural. É produzido pela empresa Beneficiadora de Minerais Curuçá Ltda., e foi fornecido pela $3 \mathrm{M}$ do Brasil Ltda.

- Massa específica: $2,50 \mathrm{~g} / \mathrm{cm}^{3}$.

- Partículas abaixo de $5 \mu: 40 \%$.

- Resíduo em 400 Mesh: 0,08\%

- Estrutura cristalina: Romboédrica

- Revestimento de silicato natural: $10 \%$

\subsection{4 - Aditivos}

Utilizou-se como estabilizante para a borracha nitrilica o produto "Santowhite ${ }^{\circledR}$ crystals", o qual corresponde quimicamente a um derivado cresol, sendo o mesmo indicado pelo próprio fabricante da borracha. $O$ produto confere excelente proteção contra o envelhecimento termo-oxidativo de borrachas. É produzido pela empresa Monsanto, e foi fornecido pela 3M do Brasil Ltda.

- Ponto de fusão: $209^{\circ} \mathrm{C}$.

- Massa específica: $1,0 \mathrm{~g} / \mathrm{cm}^{3}$.

4.1.5 - Reagentes, grau analítico: Hidróxido de sódio, acetona e detergente neutro Extran. 


\section{2 - Métodos}

\subsection{1 - Rota Experimental}

\section{Fibra de Sisal}

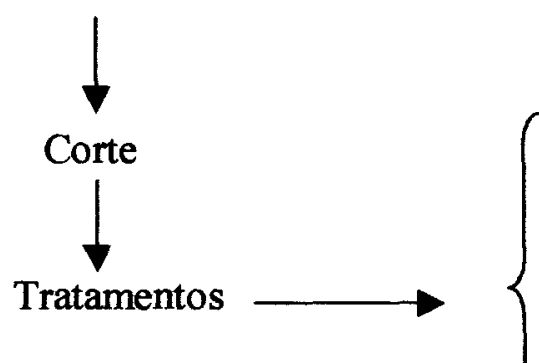

1) Lavagem com água, $1 \mathrm{~h}$ a $80^{\circ} \mathrm{C}$

2) Solução detergente Extran a $20 \%$, ih a $80^{\circ} \mathrm{C}$

3) Água com acetona $(1: 1, v: v)$; $2 \mathrm{~h}, \mathrm{~T} \mathrm{amb}$.

4) Mercerização $\mathrm{NaOH} 10 \%\left\{\begin{array}{c}3 \mathrm{~h}, \mathrm{~T} \text { amb. } \\ 5 \mathrm{~h}, \mathrm{~T} \text { amb. } \\ 10 \mathrm{~h}, \mathrm{~T} \text { amb. }\end{array}\right.$

\section{Borracha Nitrílica}

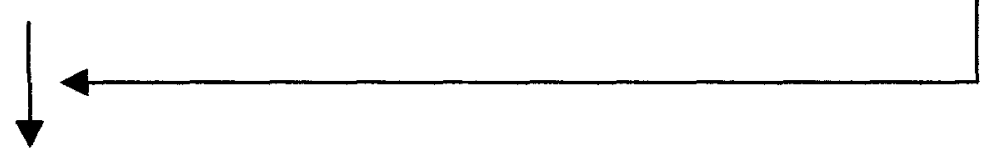

Compósitos de Borracha

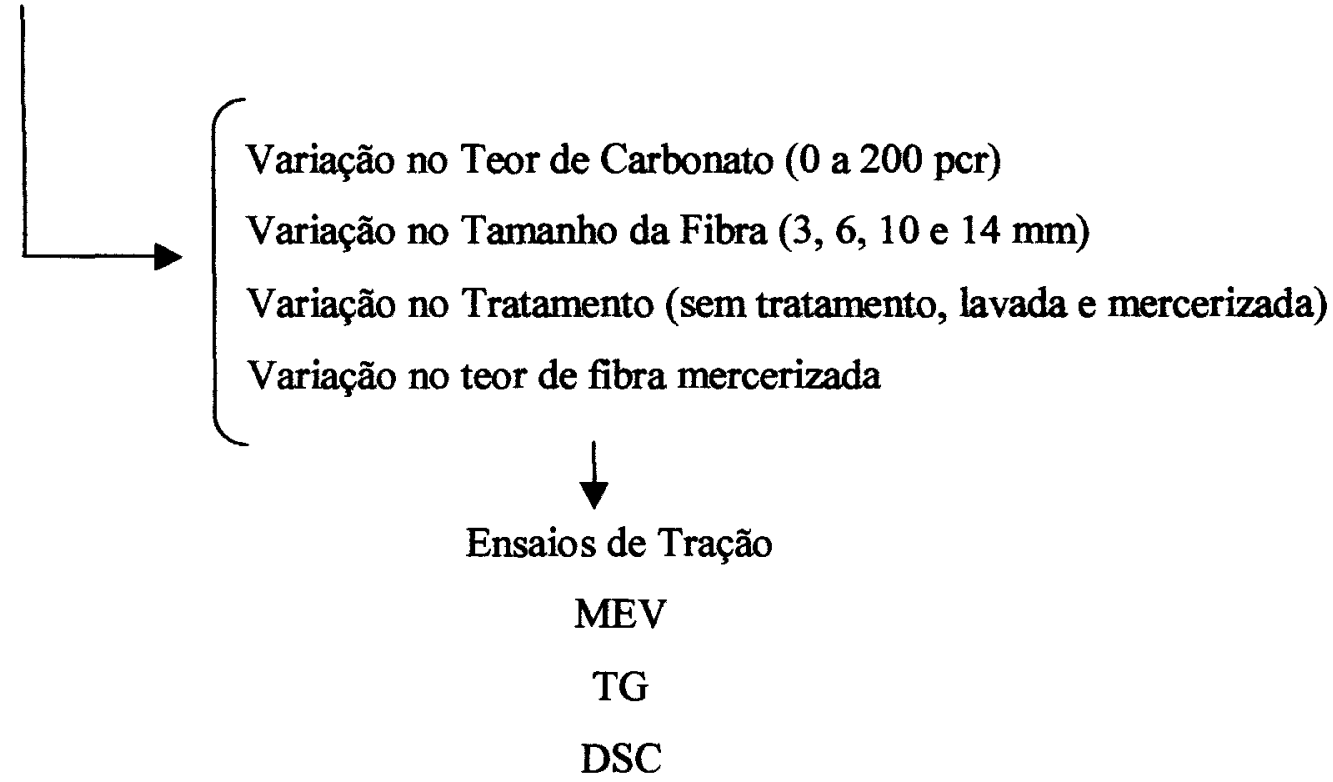




\subsection{2 - Tratamentos das Fibras de Sisal}

Diferentes tipos de tratamentos foram realizados nas fibras de sisal, visando a eliminação dos extrativos das fibras, aumentando assim sua porosidade e área de contato, e conseqüentemente a possibilidade de adesão na matriz de borracha.

Os tipos de tratamentos empregados foram os seguintes:

- Lavagem com água por um período de $1 \mathrm{~h} \mathrm{a} 80 \pm 2^{\circ} \mathrm{C}$. Após serem lavadas, as fibras foram secas em estufas por um período de $6 \mathrm{~h}$, à temperatura de aproximadamente $80^{\circ} \mathrm{C}[22]$.

- Tratamento com solução de detergente neutro Extran a 20\%, por um período de $1 \mathrm{~h}$ a $80 \pm 2^{\circ} \mathrm{C}$. Em seguida, foram lavadas abundantemente em água corrente. Na etapa seguinte, as fibras foram secas em estufas por um período de $6 \mathrm{~h}$, à temperatura de aproximadamente $80^{\circ} \mathrm{C}$.

- Tratamento com solução acetona/água (1:1, v:v) por um período de 2 $\mathrm{h}$ à temperatura ambiente. Em seguida foram lavadas abundantemente em água corrente. Na etapa seguinte, as fibras foram secas em estufas por um periodo de $6 \mathrm{~h}$, à temperatura de aproximadamente $80^{\circ} \mathrm{C}$.

- Tratamento de mercerização em solução de hidróxido de sódio $(\mathrm{NaOH})$ na concentração de $10 \%$, por períodos de 3,5 e $10 \mathrm{~h}$, à temperatura ambiente. Em seguida, foram lavadas abundantemente em água corrente até $\mathrm{pH}$ entre 6 e 7. Na etapa seguinte, as fibras foram secas em estufas por um período de $6 \mathrm{~h}$, à temperatura de aproximadamente $80^{\circ} \mathrm{C}$. Na literatura, encontra-se grande diversidade de condições para tratamento de mercerização em fibras de sisal $[19,41,58]$.

A amostragem das fibras de sisal para realização destes tratamentos e sua posterior análise por microscopia eletrônica foi feita partindo-se de um lote de aproximadamente $6 \mathrm{Kg}$ de fibras de sisal, com comprimento médio de $1,50 \mathrm{~m}$. 
Pequenos feixes de fibras inteiras foram retirados em diferentes pontos da amostra, e em seguida convertidos em fragmentos de $1 \mathrm{~cm}$ de comprimento. A amostra foi colocada num saco plástico, homogeneizada, e dividida em 7 porções para realização dos tratamentos. Tal procedimento visou obter uma representatividade de cada porção em termos de distribuição de fibras no meio de toda a amostra, bem como de fragmentos posicionados em diferentes regiões ao longo da fibra.

\subsection{3 - Corte das Fibras de Sisal}

As fibras de sisal foram cortadas em uma guilhotina industrial manual marca Funtimod, com $70 \mathrm{~cm}$ de abertura, sendo que previamente foram alinhadas em um grande feixe e mantidas firmemente unidas através da aplicação de uma fita adesiva filamentosa em toda a extensão deste feixe. $O$ produto assim compactado tinha um aspecto cilíndrico com aproximadamente $5 \mathrm{~cm}$ de diâmetro. Ao ser guilhotinado obtinha-se "fatias" com centenas de fragmentos de fibras, sendo a fita adesiva posteriormente removida e descartada.

\subsection{4 - Microscopia Eletrônica de Varredura}

A caracterização através de microscopia eletrônica de varredura (MEV) foi realizada no Laboratório de Microscopia Eletrônica do Instituto de Física da USPSC.

No estudo de MEV, analisamos as mudanças morfológicas das fibras de sisal após os tratamentos descritos no item 4.2.2 e posteriormente para a análise da superficie de fratura dos compósitos de borracha com fibras de sisal. No caso destas últimas amostras, as mesmas foram quebradas após imersão em nitrogênio líquido por $15 \mathrm{~min}$. 
Utilizou-se um microscópio eletrônico marca ZEISS modelo DSM 960, com um feixe de elétrons de $10 \mathrm{kV}$ a $20 \mathrm{kV}$ e ampliações entre $100 \mathrm{x}$ e $3000 \mathrm{x}$. As amostras foram colocadas sobre suporte de aluminio e fixadas nas bordas com tinta prata. Sobre as amostras foi depositado uma camada de ouro "sputter coater" (plasma de argônio) marca BALZERS modelo SCD 50.

No caso das análises realizadas nas fibras de sisal tratadas, 6 fragmentos de cada situação, preparados conforme amostragem descrita no item 4.2.2, foram colocados nos porta-amostras e analisados um a um. Desta forma, as imagens selecionadas e apresentadas no capítulo de resultados 5.1 são representativas dos materiais analisados.

\subsection{5 - Preparação dos Compósitos}

\subsubsection{1 - Composição}

Considerando os diversos tipos de estudos realizados, 34 diferentes formulações foram analisadas. Em todas, foi mantido o teor de antioxidante Santowhite® em 1 pcr, e os demais componentes variaram conforme descrição a seguir:

- Estudo da variação do teor de carbonato de cálcio sobre borracha nitrílica: neste estudo foram avaliadas formulações com teores de carbonato iguais a 0,11 , $33,50,67,90,133$ e 200 pcr.

- Estudo da variação do tamanho de fibra de sisal lavada sobre borracha pura; borracha com 33 pcr de carbonato de cálcio; e borracha com 67 pcr de carbonato de cálcio: Para cada uma das 3 situações acima, se utilizou fibras de sisal nos tamanhos de 3, 6, 10 e $14 \mathrm{~mm}$ de comprimento. $O$ teor de fibra foi mantido constante nestes estudos em 22 pcr. 
- Estudo da variação do tipo de tratamento efetuado nas fibras de sisal sobre borracha pura; borracha com 33 pcr de carbonato de cálcio; e borracha com 67 pcr de carbonato de cálcio: Para cada uma das situações acima se empregou fibra de sisal sem tratamento; fibra lavada com água quente; e fibra mercerizada em $\mathrm{NaOH}$ a $10 \%$ por $3 \mathrm{~h}$. Nestas 3 séries de estudos, manteve-se fixo o teor ( $22 \mathrm{pcr})$ e o tamanho (6 $\mathrm{mm})$ das fibras.

- Estudo da variação do teor de fibra mercerizada (solução de $\mathrm{NaOH}$ a $10 \%, 3$ h à temperatura ambiente) sobre borracha pura e borracha com 67 pcr de carbonato: Nestas 2 séries de estudo empregou-se teores de fibra iguais a $0,5,5,11,22,33$ e 44 pcr. O tamanho de fibra foi mantido constante em $6 \mathrm{~mm}$.

\subsubsection{2 - Processamento dos compósitos}

Os compósitos foram processados nos laboratórios da $3 \mathrm{M}$ do Brasil (Fábrica de Sumaré) em uma Calandra Mecanoplast Modelo C-400-2S composta por moinho aberto de 2 rolos. O equipamento é aquecido por sistema elétrico e dispõe de controle digital de temperatura, sendo que todas as amostras foram processadas no intervalo de temperatura compreendido entre 125 e $135^{\circ} \mathrm{C}$; a qual era constantemente monitorada diretamente nas superficies das mantas, através de um termômetro equipado com sensor infravermelho.

O tempo total para processamento dos compósitos foi estabelecido em 20 min, distribuídos da seguinte forma: 5 min para mastigação da borracha (e incorporação do estabilizante térmico); $5 \mathrm{~min}$ para incorporação do carbonato de cálcio; 5 min para incorporação das fibras de sisal; e 5 min para homogeneização da massa. As amostras que não apresentavam carbonato em sua composição tinham os 5 min para adição deste componente incorporados ao tempo de mastigação da 
borracha; de forma que todas as amostras ficaram em processamento no moinho durante o intervalo de tempo de $20 \mathrm{~min}$.

A adição das fibras de sisal era feita na última etapa, de modo às mesmas sofrerem o mínimo efeito possível de quebras durante o processamento. Visando ainda minimizar este efeito inerente de quebras, tomou-se o cuidado de trabalhar a massa sempre no mesmo sentido, de modo a ter-se observado a existência de uma leve tendência de orientação das fibras no sentido longitudinal de processamento das mesmas.

Cada uma das 34 formulações foi preparada partindo-se de $200 \mathrm{~g}$ de borracha nitrílica. Ressalta-se aqui que não foi de interesse neste trabalho em proceder-se à vulcanização da borracha.

Embora dispondo de dispositivo graduado para controle de abertura entre os rolos, cada uma das mantas provenientes de diferentes formulações era retirada numa determinada abertura, em função dos diferentes graus de retração dimensional apresentados durante $o$ processo natural de resfriamento das amostras. Tal procedimento visou uma melhor uniformidade na espessura dos corpos de prova.

\subsection{6 - Ensaios de Resistência à Tração}

Foram realizados nos laboratórios da $3 \mathrm{M}$ do Brasil (Fábrica de Ribeirão Preto), em uma Máquina de Ensaio Universal - EMIC DL $500 \mathrm{MF}$, utilizando o programa M-Test, versão 1.0, segundo a norma ASTM D 412-98a, método A [72], com as seguintes condições: abertura entre garras de $50 \mathrm{~mm}$, velocidade de deslocamento das garras igual a $500 \mathrm{~mm} / \mathrm{min}$, célula de $100 \mathrm{~N}$. Os corpos de prova foram condicionados por $24 \mathrm{~h}$ à temperatura de $23 \pm 2^{\circ} \mathrm{C}$. Foram realizados 5 ensaios para cada tipo de composto, cujos corpos de prova foram sempre retirados no sentido 
longitudinal de processamento das amostras. A espessura dos mesmos foi determinada com um paquímetro Mahr.

\subsection{7 - Análise Termogravimétrica (TG)}

As análises termogravimétricas foram realizadas em um equipamento NETZSCH modelo TG 209, com início à temperatura ambiente até $600^{\circ} \mathrm{C}$, com uma taxa de aquecimento de $10^{\circ} \mathrm{C} / \mathrm{min}$, usando nitrogênio como gás de arraste, com fluxo de $15 \mathrm{ml} / \mathrm{min}$. Ensaios realizados na UNESP - Presidente Prudente.

\subsection{8 - Calorimetria Exploratória Diferencial (DSC)}

Foi utilizado um instrumento NETZSCH modelo DSC 204, em uma faixa de temperatura de $-100^{\circ} \mathrm{C}$ a $400^{\circ} \mathrm{C}$, com uma taxa de aquecimento de $10^{\circ} \mathrm{C} / \mathrm{min}$, usando nitrogênio como gás de arraste, com fluxo de $30 \mathrm{ml} / \mathrm{min}$. Ensaios realizados na UNESP - Presidente Prudente. 


\section{5 - RESULTADOS E DISCUSSÃO}

\section{1 - Análise Microscópica das Fibras de Sisal por MEV}

Visando definir os tipos de tratamento que seriam utilizados no decorrer do estudo, iniciou-se o trabalho com a análise por MEV das fibras de sisal.

A Figura 5 mostra a superfície longitudinal de uma fibra natural, na forma em que é recebida, sem qualquer tipo de tratamento laboratorial, onde podemos observar as células de parênquima envolvendo a fibra, bem como resíduos do processo de beneficiamento das fibras. Estudos realizados por Varghese e colaboradores [23] e por Joseph e colaboradores $[39,41]$ mostram que os residuos presentes na superficie das fibras vegetais diminuem a adesão quando estas fibras são utilizadas em materiais compósitos.

As figuras subseqüentes, Figuras 6-11, mostram o efeito dos diferentes tratamentos realizados com as fibras de sisal. Na Figura 6 podemos observar que a simples lavagem com água quente remove grande parte dos resíduos de beneficiamento da fibra. Kumar \& Thomas [62] relatam em um de seus trabalhos que a lavagem de fibras de sisal com água, a frio, remove parcialmente a lignina da superficie das fibras, deixando-a mais rugosa. Na Figura 7, percebe-se que a solução de detergente tende a interagir com as células de parênquima, porém sem conseguir removê-las. $\mathrm{O}$ tratamento das fibras com solução de água com acetona retira as impurezas de beneficiamento, mas também não consegue remover com grande eficiência as células de parênquima, conforme observado na Figura 8. 


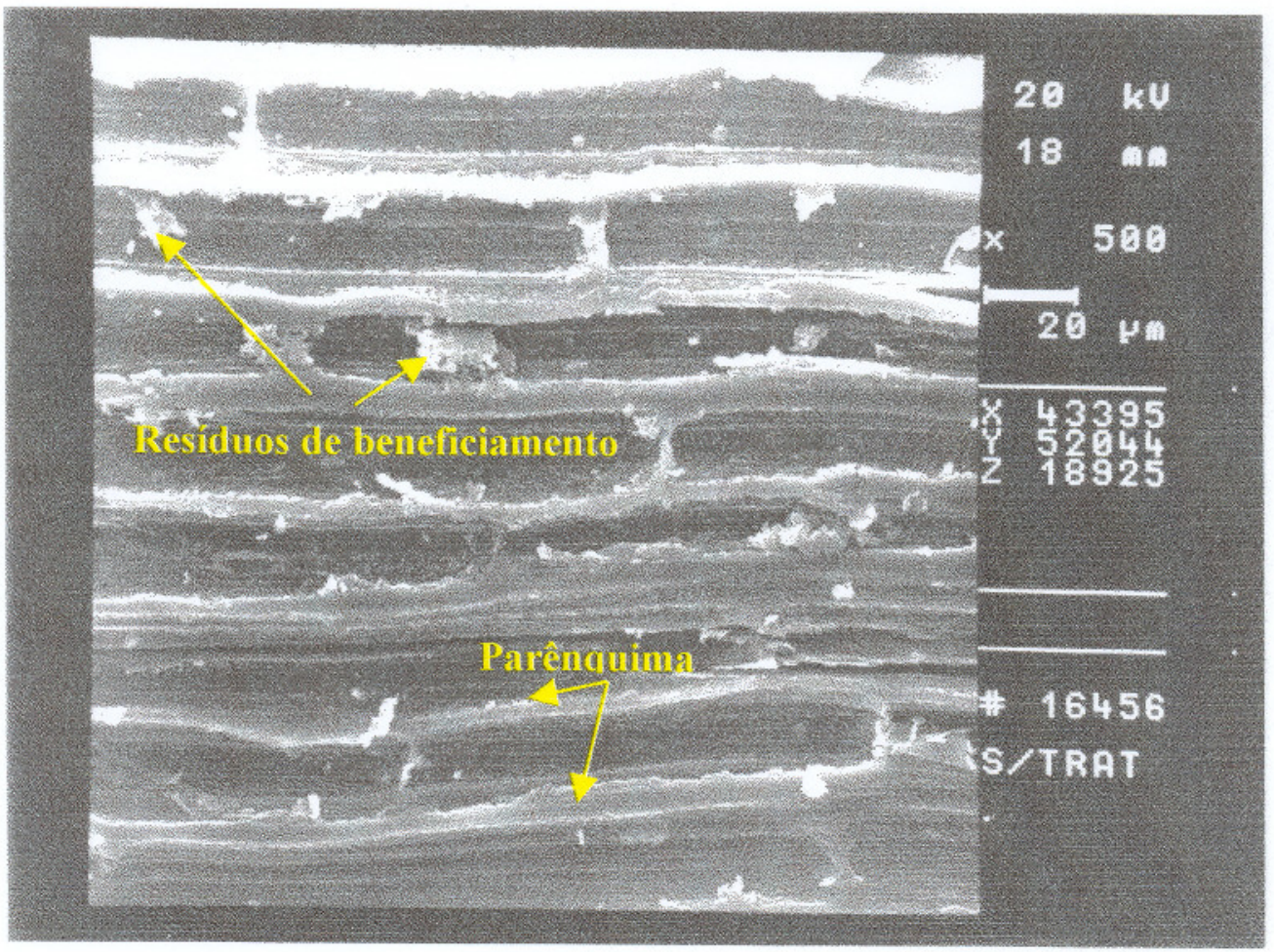

Figura 5 - Micrografia obtida por MEV da superficie longitudinal de uma fibra de sisal sem tratamento. Ampliação de 500 x.

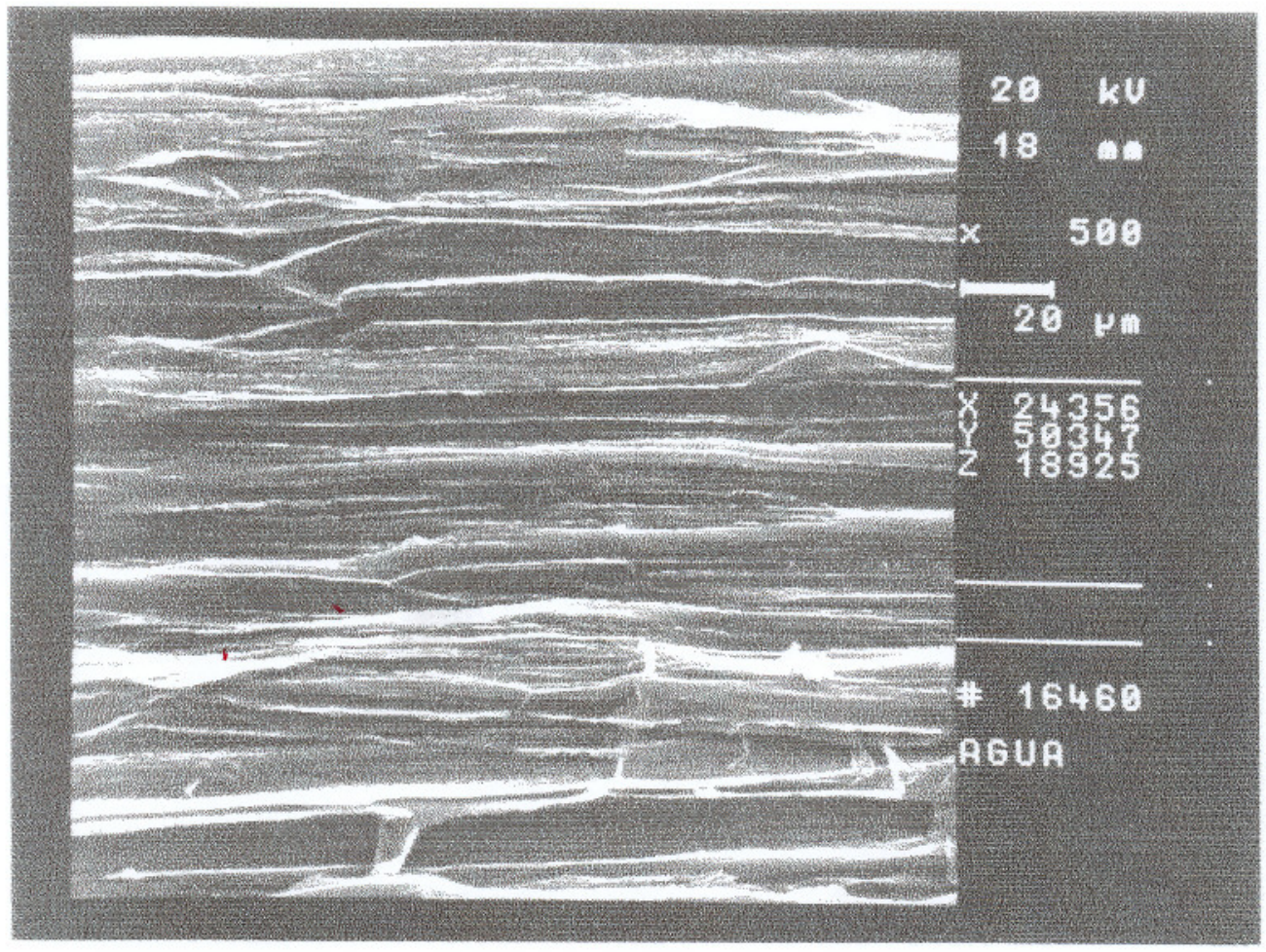

Figura 6 - Micrografia obtida por MEV da superfície longitudinal de uma fibra de sisal lavada com água, durante $1 \mathrm{~h}$ a $80^{\circ} \mathrm{C}$. Ampliação de $500 \mathrm{x}$. 


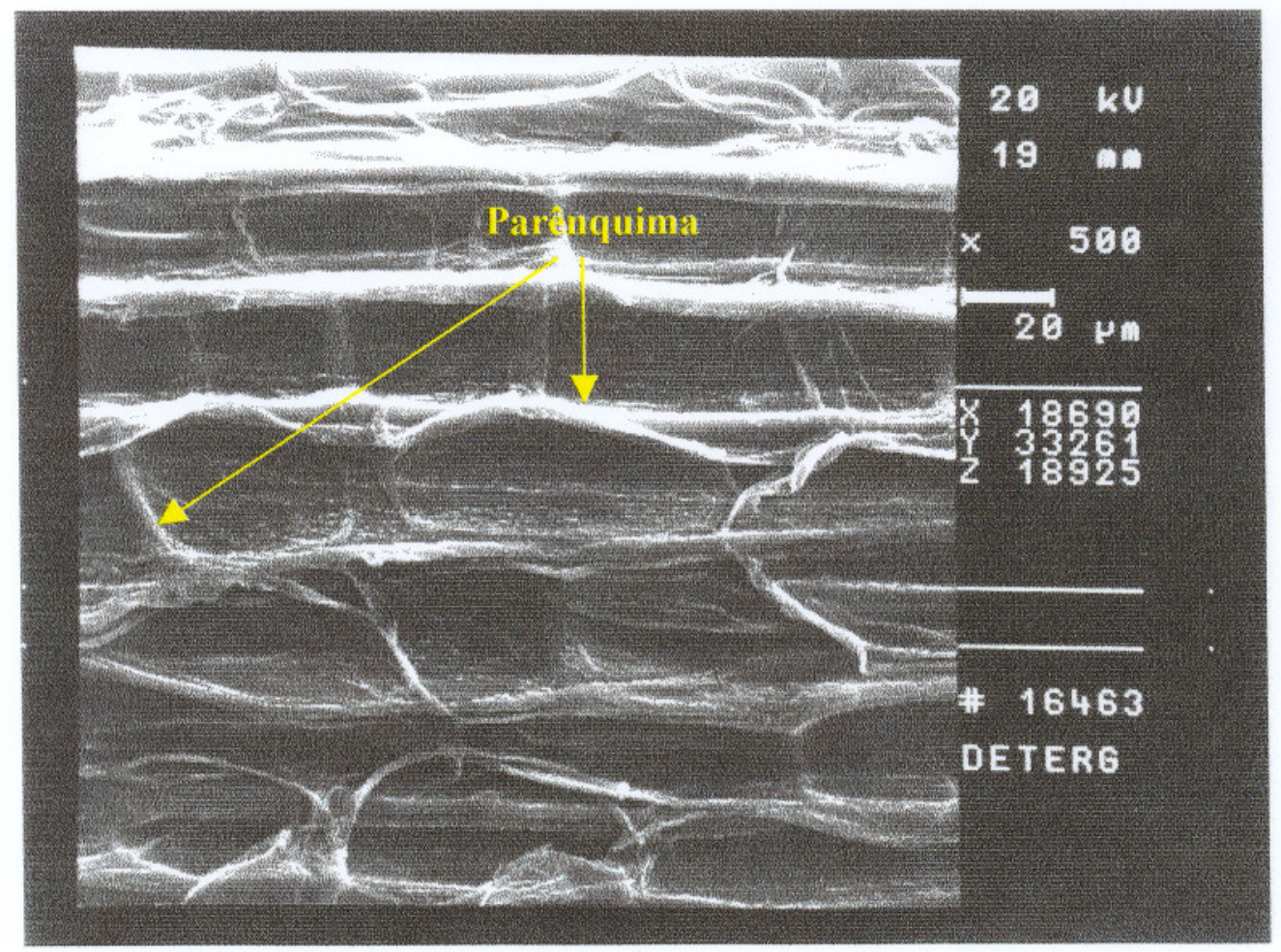

Figura 7 - Micrografia obtida por MEV da superfície longitudinal de uma fibra de sisal tratada com solução de detergente neutro a $20 \%$, durante $1 \mathrm{~h}$ a $80^{\circ} \mathrm{C}$. Ampliação de $500 \mathrm{x}$.

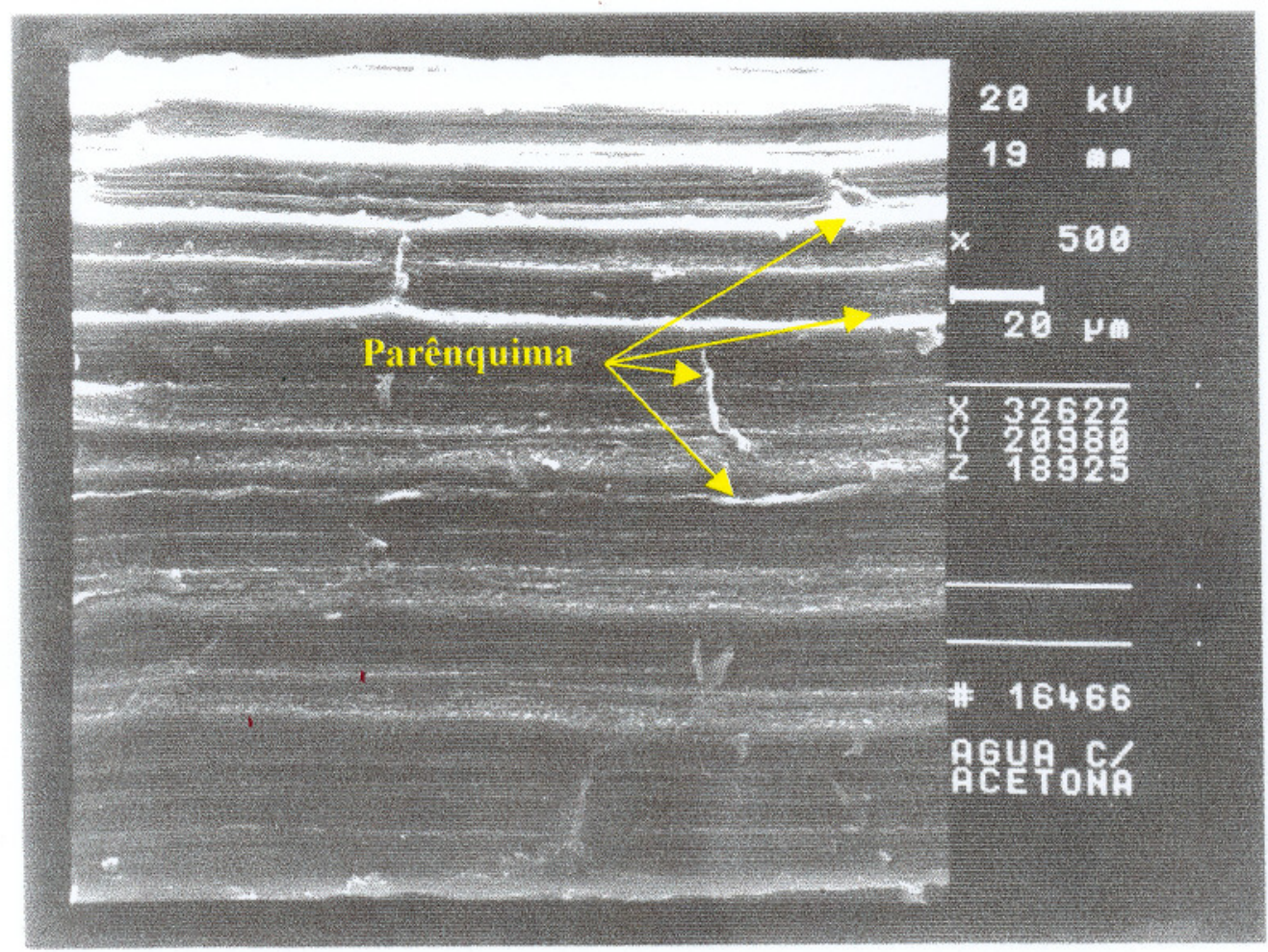

Figura 8 - Micrografia obtida por MEV da superfície longitudinal de uma fibra de sisal tratada com solução de água/acetona $(1: 1, \mathrm{v}: \mathrm{v})$, durante $2 \mathrm{~h}, \mathrm{~T}$ ambiente. Ampliação de $500 \mathrm{x}$. 
As Figuras 9-11 mostram o efeito do tratamento de mercerização nas fibras. Conforme pode ser observado, este tratamento além de remover impurezas de beneficiamento, remove grande parte das células de parênquima, expondo as fibrilas que constituem as fibras de sisal. Percebe-se ainda que os diferentes tempos de mercerização aplicados neste estudo, não promovem diferenças significativas entre si na superfície das fibras; ou seja, nas três situações expõe-se os feixes de fibrilas unidas entre si, mas ainda estão presentes células de parênquima.

Em virtude destes resultados, optou-se inicialmente pelo uso de fibras de sisal lavadas com água a $80^{\circ} \mathrm{C}$, por um período de $1 \mathrm{~h}$. Após definição do tamanho crítico de fibra, foi analisado a influência do tratamento de mercerização (solução de $\mathrm{NaOH}$ a $10 \% ; 3$ h; T ambiente) no comportamento das características mecânicas dos compósitos.

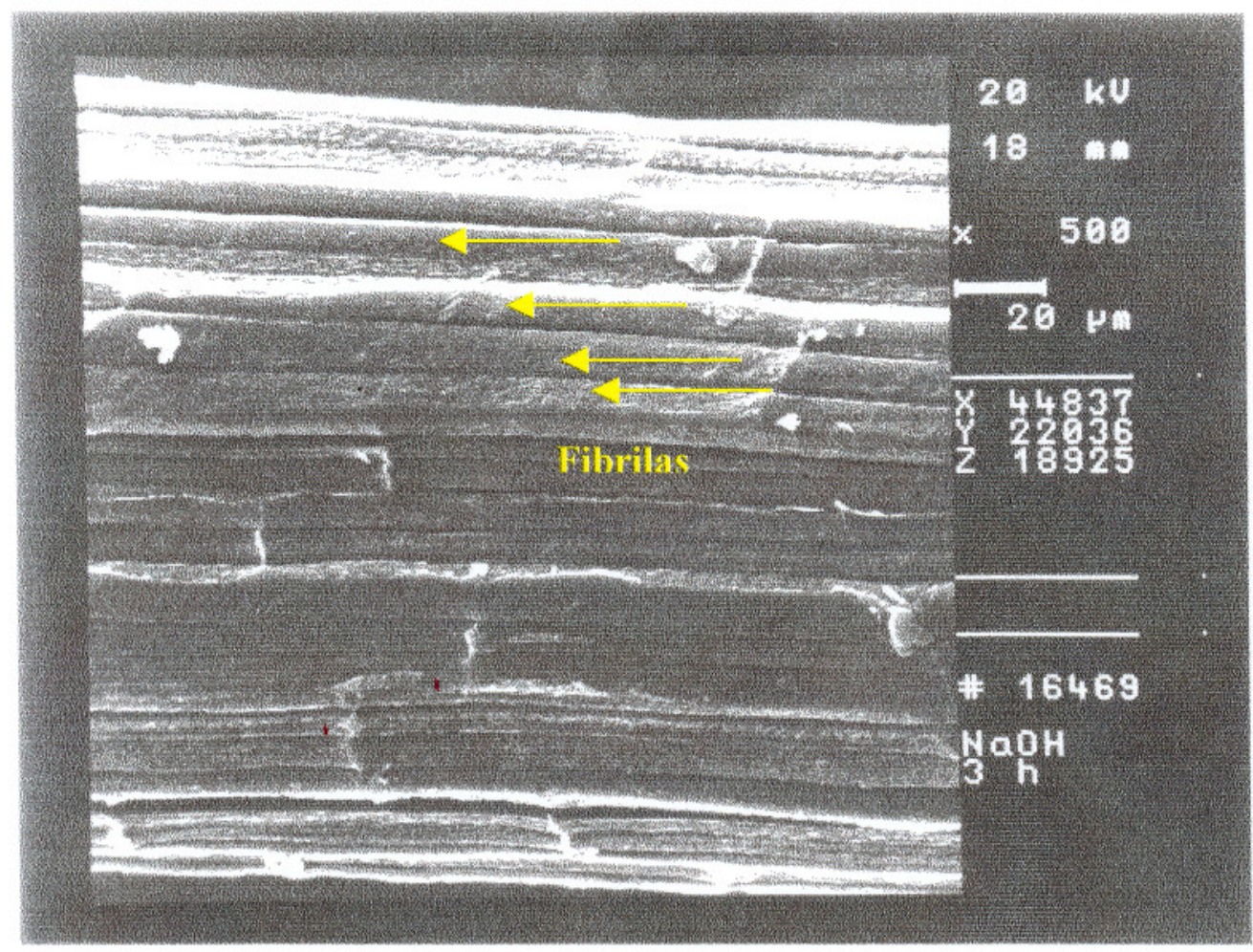

Figura 9 - Micrografia obtida por MEV da superfície longitudinal de uma fibra de sisal mercerizada com solução de $\mathrm{NaOH}$ a $10 \%$, durante 3 h, T ambiente. Ampliação de $500 \mathrm{x}$. 


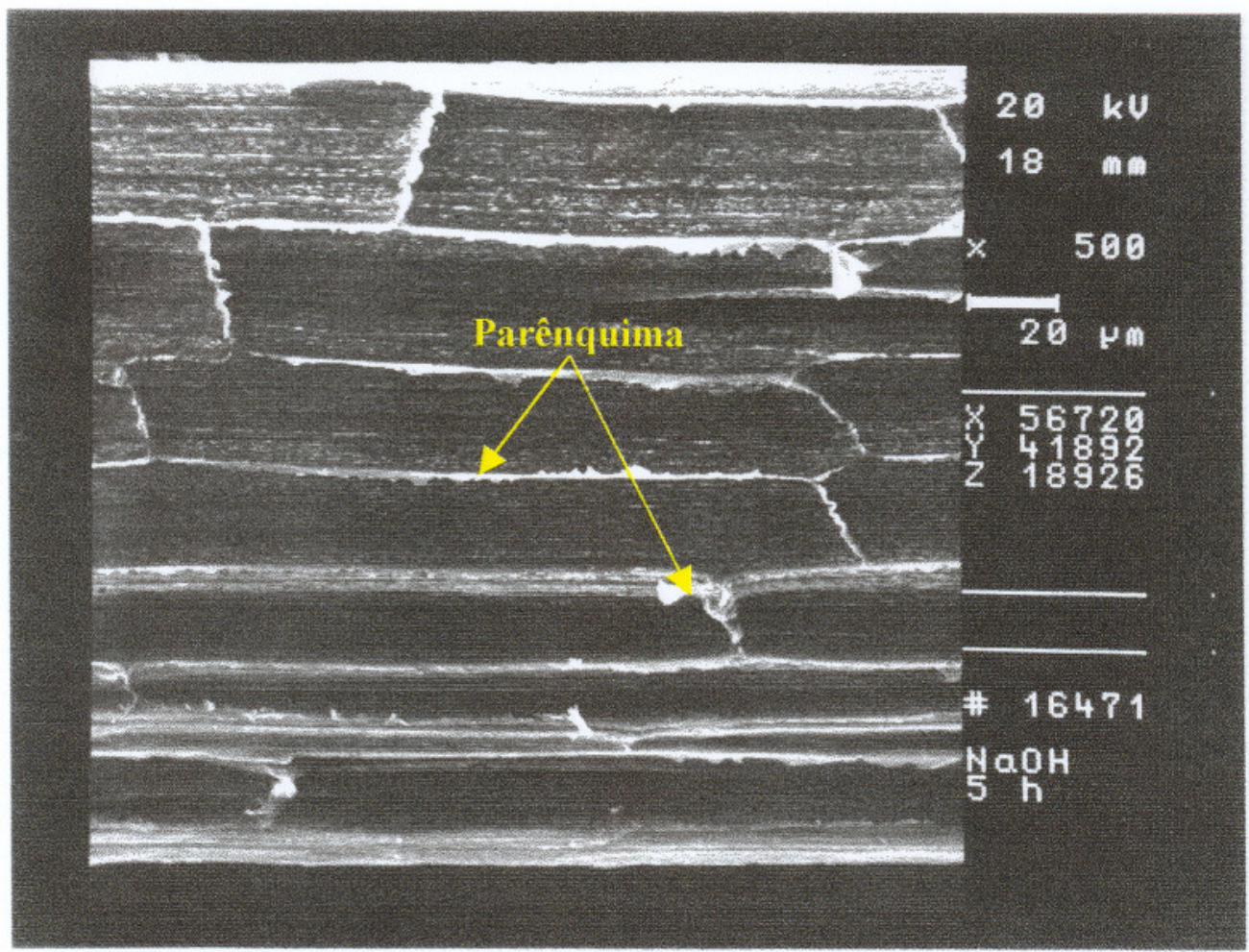

Figura 10 - Micrografia obtida por MEV da superficie longitudinal de uma fibra de sisal mercerizada com solução de $\mathrm{NaOH}$ a $10 \%$, durante 5 h, T ambiente. Ampliação de $500 \mathrm{x}$.

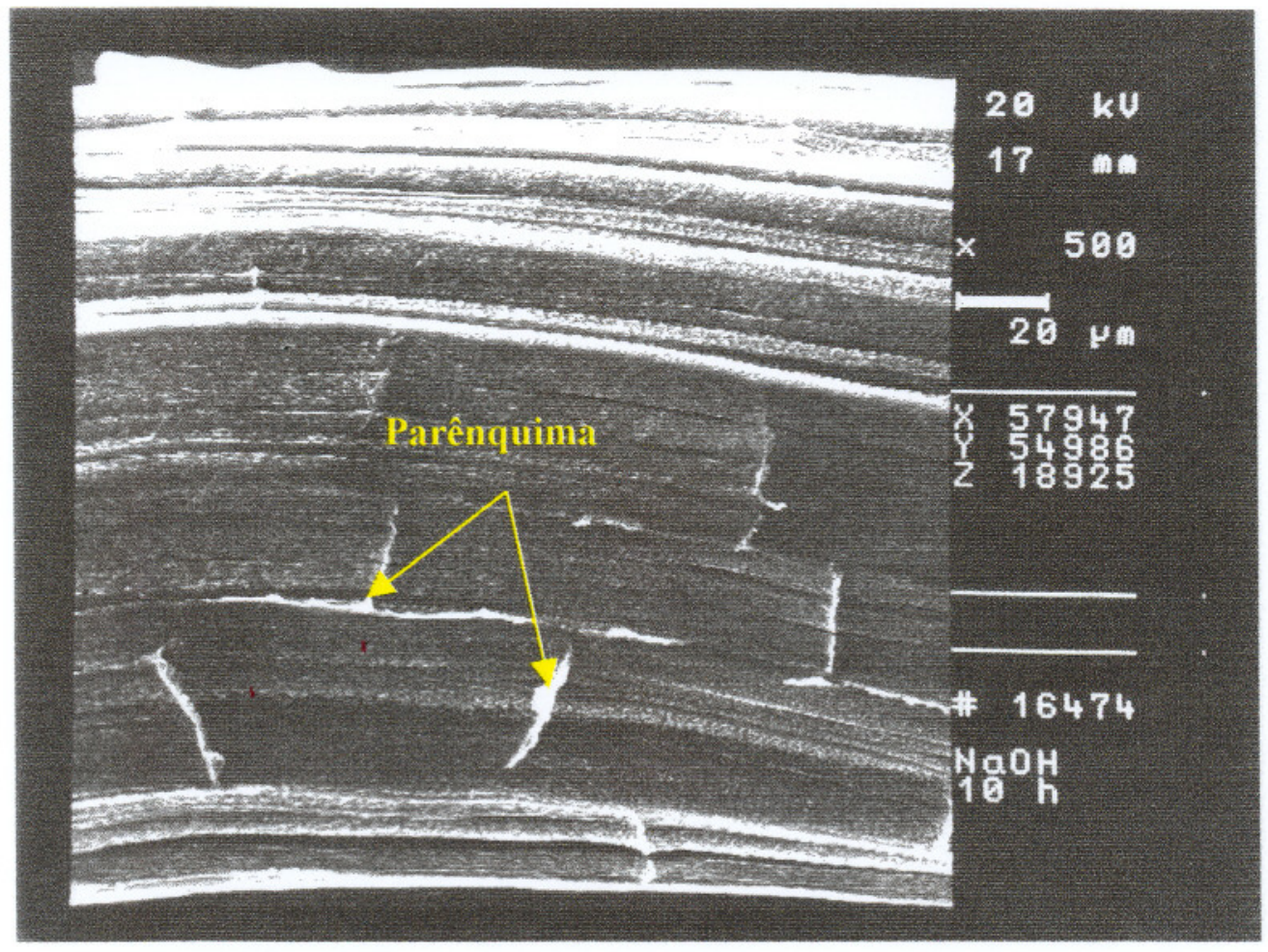

Figura 11 - Micrografia obtida por MEV da superficie longitudinal de uma fibra de sisal mercerizada com solução de $\mathrm{NaOH}$ a $10 \%$, durante $10 \mathrm{~h}, \mathrm{~T}$ ambiente. Ampliação de 500 x. 


\section{2 - Corte das Fibras de Sisal}

Com o objetivo de se verificar a eficiência da metodologia de corte empregado neste trabalho, obteve-se em torno de 300 fragmentos de fibra de cada um dos 4 tamanhos nominais escolhidos para estudo, e com uma lupa graduada Bausch \& Lomb determinou-se o comprimento de cada fragmento. A distribuição obtida encontra-se na Figura 12.

Os tamanhos de fibra usados para análise neste trabalho foram escolhidos a partir de referências encontradas na literatura [41, 61-62], em que a maioria dos compósitos estudados apresentou melhorias em suas propriedades quando as fibras de sisal eram empregadas em fragmentos compreendidos na faixa de 6 a $10 \mathrm{~mm}$. Escolheu-se, portanto, além dos comprimentos de 6 e $10 \mathrm{~mm}$, um de medida inferior $(3 \mathrm{~mm})$ e outro de medida superior $(14 \mathrm{~mm})$.

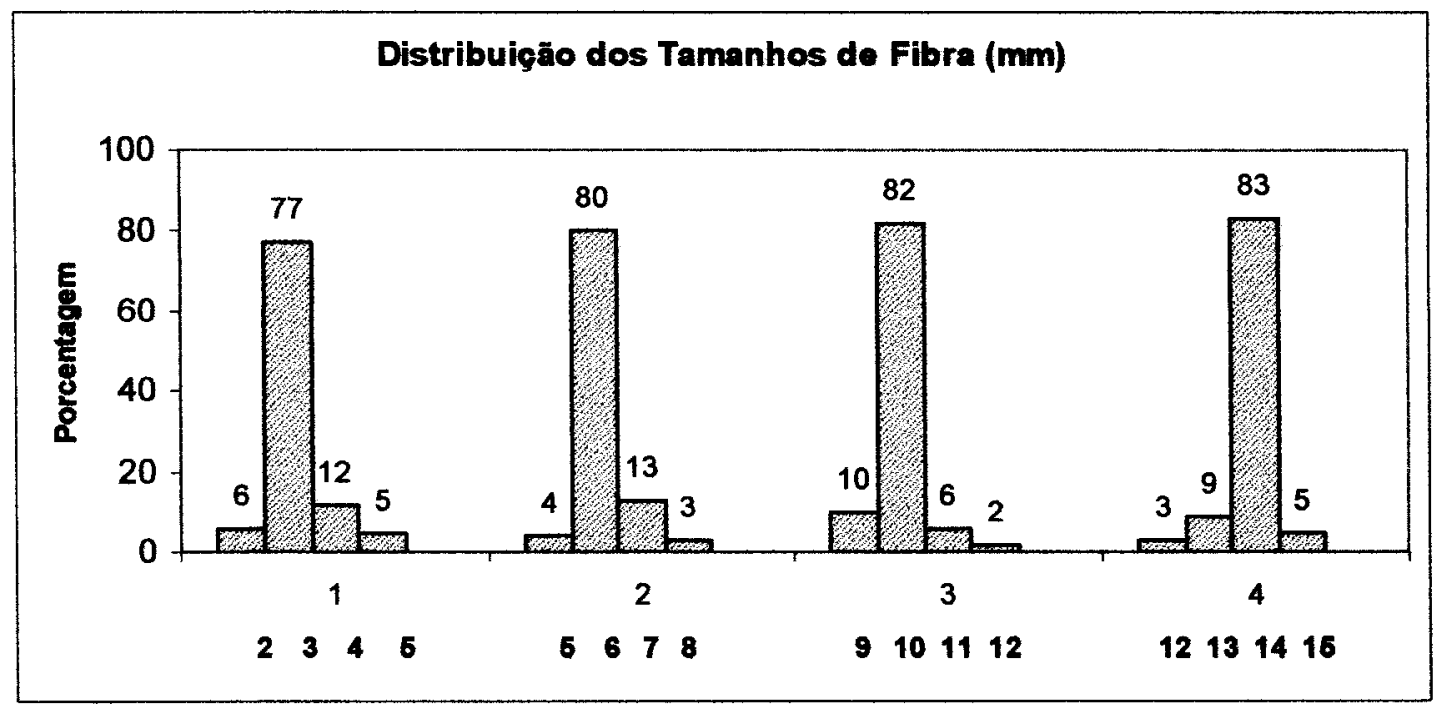

Figura 12: Distribuição percentual dos tamanhos de fibra obtidos para cada um dos quatro tamanhos nominais usados (conjunto de valores $1=3 \mathrm{~mm}$ nominal, conjunto de valores $2=6 \mathrm{~mm}$ nominal, conjunto de valores $3=10 \mathrm{~mm}$ nominal, conjunto de valores $4=14 \mathrm{~mm}$ nominal). 


\section{3 - Propriedades Mecânicas sob Tração dos Compósitos}

\subsection{1 - Estudo da Variação do Teor de Carbonato sobre Borracha Nitrílica}

Como um dos objetivos do trabalho é verificar o comportamento da fibra de sisal como reforço em matriz de borracha nitrílica pura e matriz de borracha nitrílica com carbonato de cálcio, o primeiro estudo de compósitos feito correspondeu à variação do teor de carbonato sobre a borracha, visando determinar a composição que traria propriedades mecânicas mais significativas; a partir da qual seriam incorporadas as fibras de sisal.

Na Figura 13 pode ser visto o comportamento encontrado para cada uma das propriedades estudadas: elongação na ruptura, tensão na ruptura e módulo a 10\% de elongação. Na faixa de composições estudadas, observa-se que qualquer que seja o teor de carbonato empregado, sempre existe um aumento na elongação do compósito quando comparado com a borracha pura; comportamento este esperado quando se adiciona carbonato de cálcio, segundo a literatura [2]. O máximo de elongação encontrado foi para o teor de 67 pcr de carbonato. Observa-se que a adição gradativa de carbonato aumenta o valor de tensão de ruptura, atingindo um máximo na formulação com 33 pcr; a partir do qual inicia-se um decaimento nesta propriedade. Este comportamento de reforço do carbonato, aumentando a resistência na tensão de ruptura não é comumente observado nos compósitos. Provavelmente, existe uma adesão bastante eficiente na interface borracha-carga, podendo ser proveniente da interação entre os grupos polares do carbonato com os da borracha, que faz com que o carbonato sólido reforce a matriz nitrilica. Esta resistência à tração na ruptura passa por um máximo, dando indícios de que a partir deste ponto a interação entre partículas de carbonato passa a ter grande relevância, diminuindo a resistência do compósito. Quanto ao módulo a $10 \%$, existe em todo intervalo estudado uma 


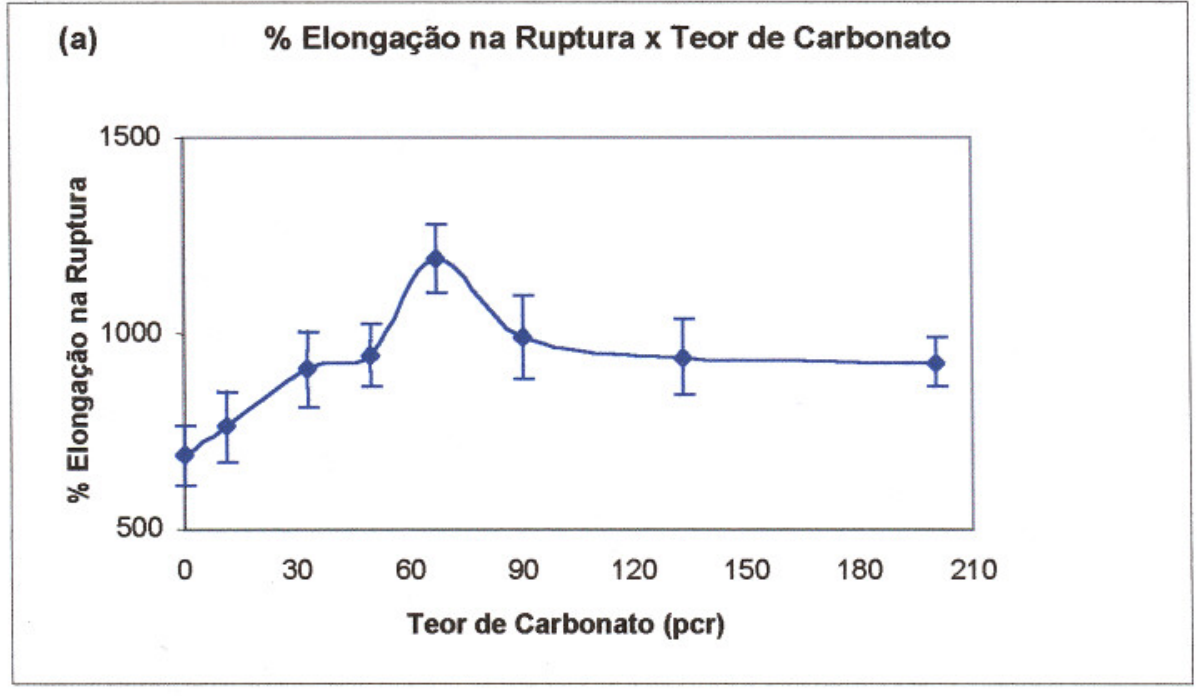

(b) Tensão na Ruptura x Teor de Carbonato

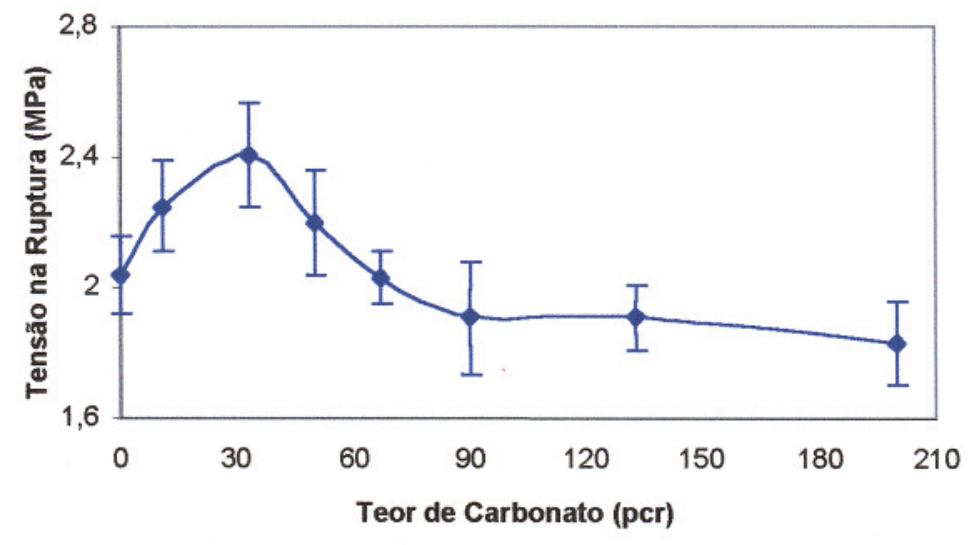

(c) Módulo de elasticidade a $10 \% \times$ Teor de Carbonato

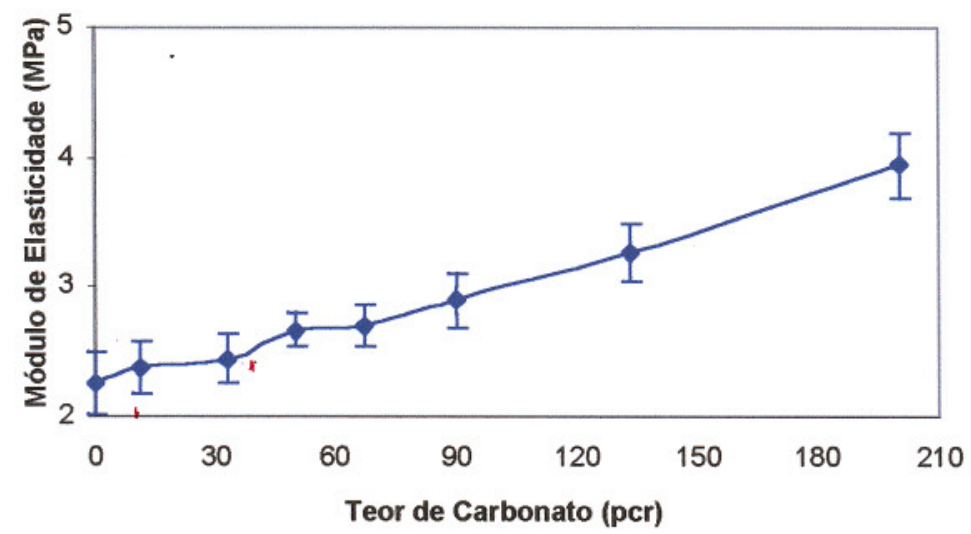

Figura 13: Curvas de (a) \% de elongação na ruptura, (b) Tensão na ruptura e (c) Módulo de elasticidade a $10 \%$ de elongação, para o estudo da variação de teor de carbonato de cálcio sobre borracha nitrílica. 
correspondência diretamente proporcional entre o teor de carbonato incorporado e o módulo do compósito.

Na Figura 14 encontra-se um conjunto de curvas representativas de Força (N) em função da deformação $(\mathrm{mm})$ características do comportamento obtido nos ensaios de tração. Conforme explicado no item 4.2.5.2, existem diferenças de espessuras entre os corpos de prova provenientes de formulações diferentes, as quais são levadas em consideração nos cálculos dos valores de tensão de ruptura e módulo de elasticidade a $10 \%$ de elongação. No Anexo A encontram-se os resultados médios das propriedades mecânicas obtidas nestes ensaios.

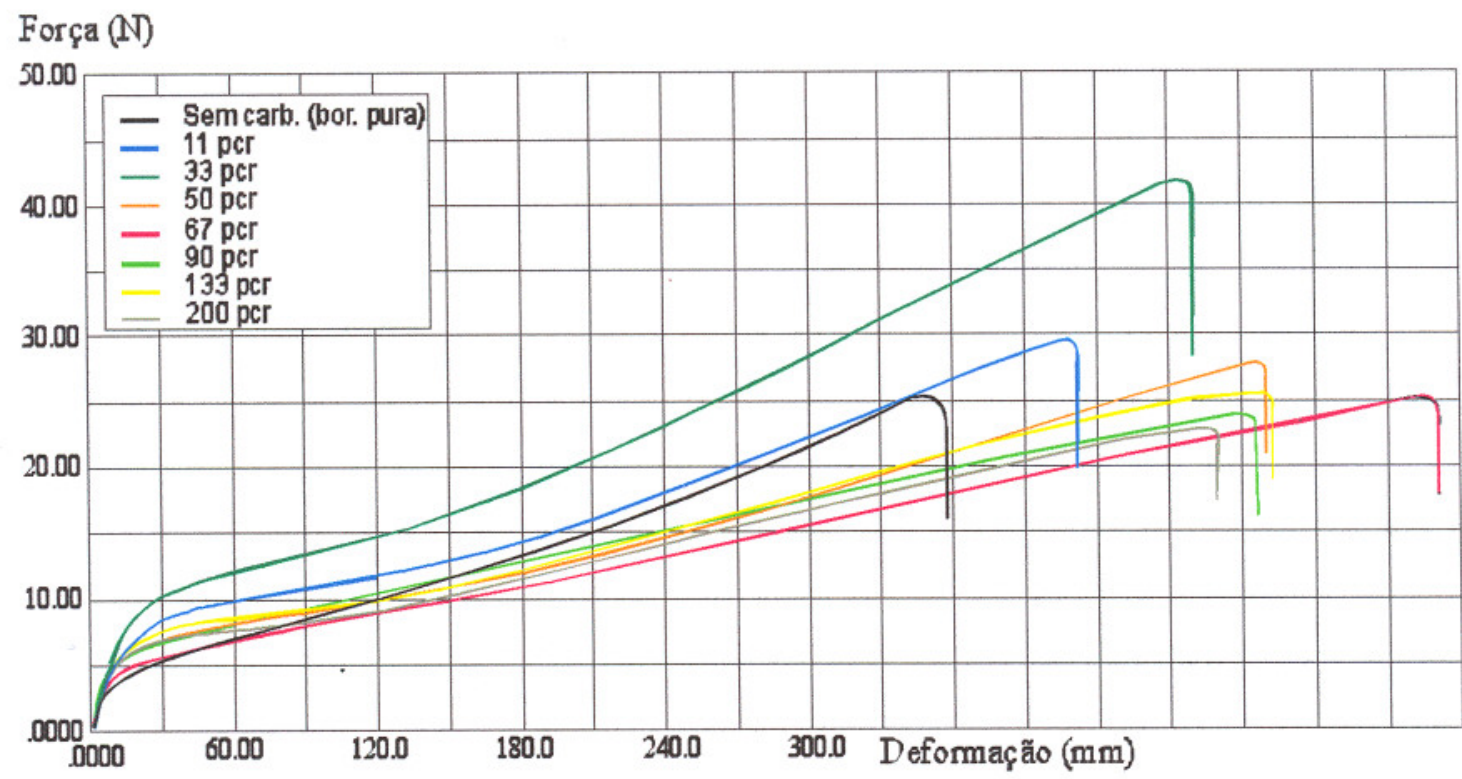

Figura 14 : Curvas representativas de Força $(\mathrm{N})$ x Deformação (mm), obtidas em ensaios de tração. Estudo da variação do teor de carbonato de cálcio sobre borracha nitrílica.

Em função dos resultados obtidos, optou-se por dar continuidade ao estudo incorporando-se fibras de sisal nas formulações contendo 33 e 67 pcr de carbonato, as quais apresentaram respectivamente maior tensão de ruptura e maior porcentagem de elongação. 


\subsection{2 - Estudo da Variação do Tamanho de Fibra de Sisal}

O objetivo desta etapa foi avaliar a influência do tamanho de fibras de sisal nas propriedades mecânicas dos compósitos, determinando-se aquele que mais impacta nos resultados. Conforme citado, os tamanhos de fibra escolhidos foram 3, 6,10 e $14 \mathrm{~mm}$ de comprimento, sendo usado nesta parte dos estudos fibras de sisal lavadas em água por $1 \mathrm{~h} \mathrm{a} 80^{\circ} \mathrm{C}$. A investigação foi feita sobre borracha nitrilica pura, e borracha com 33 e 67 pcr de carbonato, mantendo-se constante o teor de fibra em 22 pcr. Este teor de fibra foi escolhido tomando-se por referência resultados obtidos por Joseph e colaboradores [37] que detectaram que o sisal reforça borracha natural apenas em teores acima de 10 pcr; e Kumar \& Thomas [62] que encontraram que 35 pcr de fibras de sisal promovem o melhor reforço em compósitos de borracha SBR. Escolheu-se, portanto, o valor médio em relação a estes 2 trabalhos literários.

A Figura 15 mostra as curvas obtidas, referentes às propriedades mecânicas analisadas. Para qualquer dos tamanhos de fibra empregado, existe uma queda na elongação, tanto para borracha pura como para a composição que inclui o carbonato.

Nas curvas referentes à tensão de ruptura, também se observa um declínio da tensão dos compósitos para qualquer um dos tamanhos de fibra investigados. No entanto, percebe-se que para qualquer um dos três compósitos (borracha pura, borracha com 33 pcr de carbonato e borracha com 67 pcr de carbonato) o tamanho de fibra de $6 \mathrm{~mm}$ é aquele que apresenta a menor redução no valor de tensão.

Quanto ao módulo a 10\%, percebe-se que independente do tamanho da fibra de sisal empregado, as mesmas sempre provocam um aumento nesta propriedade dos compósitos, seja a matriz de borracha pura ou em associação com o carbonato de cálcio. Novamente observa-se que fibras no tamanho de $6 \mathrm{~mm}$ promovem um máximo valor de módulo, para qualquer um dos compósitos. 

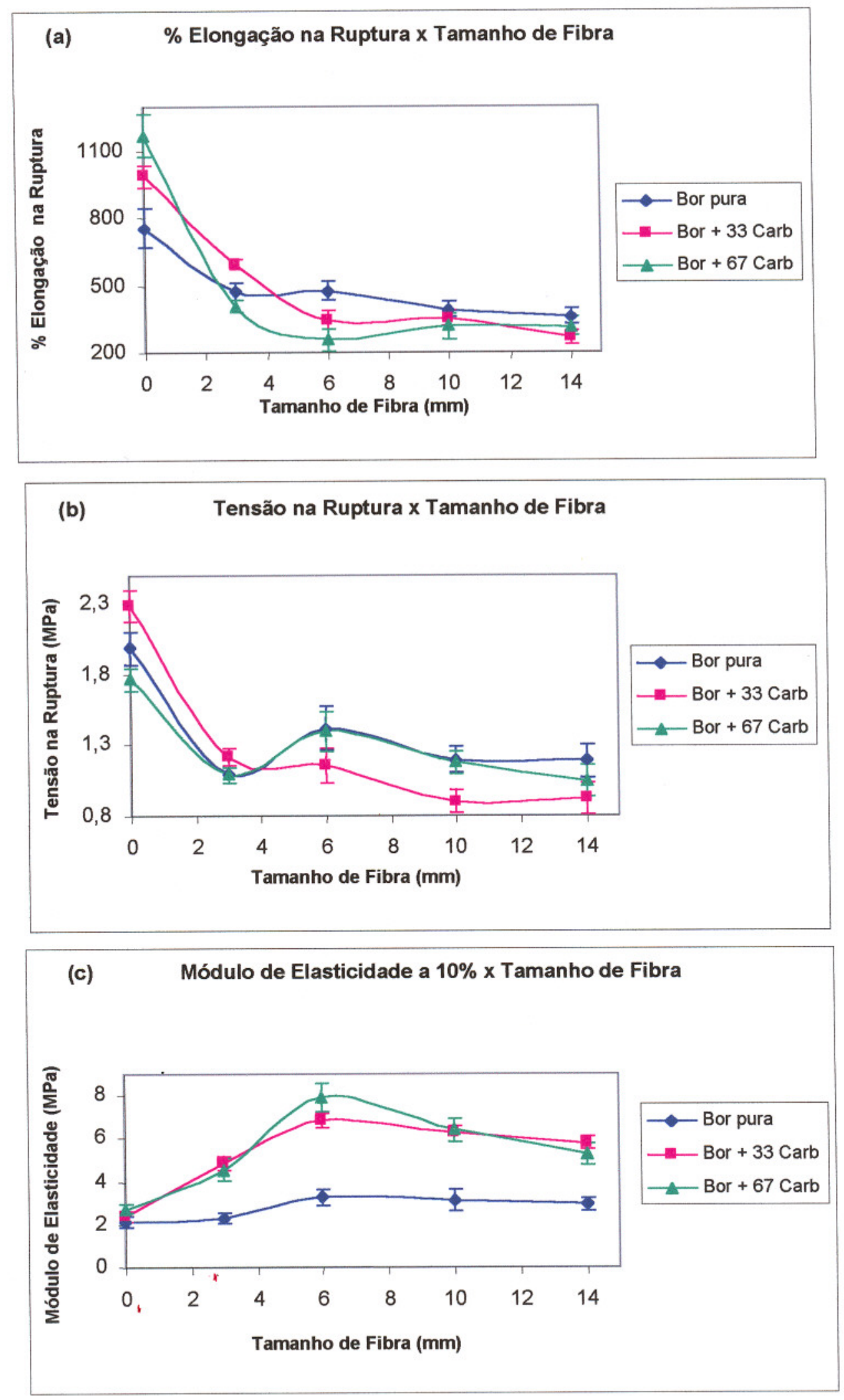

Figura 15: Curvas de (a) \% de elongação na ruptura, (b) Tensão na ruptura e (c) Módulo de elasticidade a $10 \%$ de elongação, para o estudo da variação do tamanho de fibra de sisal lavada em água quente, sobre borracha nitrílica pura; borracha nitrílica com 33 per de carbonato; e borracha nitrílica com 67 pcr de carbonato. 
Em virtude de otimizar o módulo dos compósitos e ser responsável pelo menor decaimento da tensão de ruptura dos mesmos, o tamanho de $6 \mathrm{~mm}$ mostra ser o mais adequado para reforço nos sistemas de matrizes aqui estudados, bem como nas condições de processamento aqui empregadas. Kumar \& Thomas [62], estudando os efeitos da variação do tamanho de fibras de sisal em matriz de borracha SBR, também encontraram que o tamanho de $6 \mathrm{~mm}$ proporcionou as melhores propriedades mecânicas ao compósito. $\mathrm{O}$ comprimento mínimo de fibra requerido para que a tensão na fibra seja igual à resistência máxima de ruptura da fibra em sua porção média é denominado de comprimento crítico $\left(l_{c}\right)$ da fibra. Quando o comprimento da fibra $\left(l_{f}\right)$ é menor que $1_{c}$, a tensão máxima na fibra pode nunca atingir a sua resistência máxima de ruptura. Nesta situação, ou a ligação na interface fibra-matriz, ou a matriz, pode falhar antes que a fibra atinja seu potencial de resistência. Neste caso, não haverá falha da fibra, porém a falha na ligação interfacial faz com que a fibra se desprenda da matriz. Quando $l_{\mathrm{f}}>\mathrm{l}_{\mathrm{c}}$, a tensão máxima sofrida pela fibra pode alcançar a sua resistência máxima de ruptura, ocorrendo falha da fibra. Quando $l_{\mathrm{f}}=1_{c}$, ocorre um reforço efetivo da fibra no compósito, utilizando a resistência máxima da fibra. A transmissão de carga máxima da matriz à fibra é possivel neste tamanho crítico de fibra.

Outro aspecto a ser considerado é que o teor de fibras foi mantido constante. Quanto menor o tamanho dos fragmentos, maior é a quantidade destas partículas, e conseqüentemente maior é a quantidade de pontas no compósito. Como cada ponta consiste num defeito na estrutura do compósito, quanto mais pontas estiverem presentes, maior é a fragilidade do compósito. Por outro lado, fragmentos de fibra com tamanhos superiores a $6 \mathrm{~mm}$ podem reduzir a resistência do compósito devido ao emaranhamento de fibras, resultando em pobre dispersão das mesmas. 
Fragmentos de fibra de sisal superiores a $10 \mathrm{~mm}$ causam dificuldade na incorporação das fibras na matriz elastomérica, uma vez que a dispersão das fibras não é uniforme devido ao aumento na interação fibra-fibra [62]. Nestes gráficos da Figura 15 percebe-se também que no tamanho de $6 \mathrm{~mm}$ de fibra, a matriz de borracha com 67 pcr de carbonato apresenta valores de tensão e módulo superiores ao da matriz com 33 pcr.

$\mathrm{Na}$ Figura 16 pode ser visto um conjunto de curvas características representativas de Força $(\mathrm{N})$ em função da deformação $(\mathrm{mm})$, obtido nestas avaliações. Conforme explicado no item 4.2.5.2, existem diferenças de espessuras entre os corpos de prova provenientes de formulações diferentes, as quais são levadas em consideração nos cálculos dos valores de tensão de ruptura e módulo de elasticidade a $10 \%$ de elongação. No Anexo B encontram-se os resultados médios das propriedades mecânicas obtidas. 

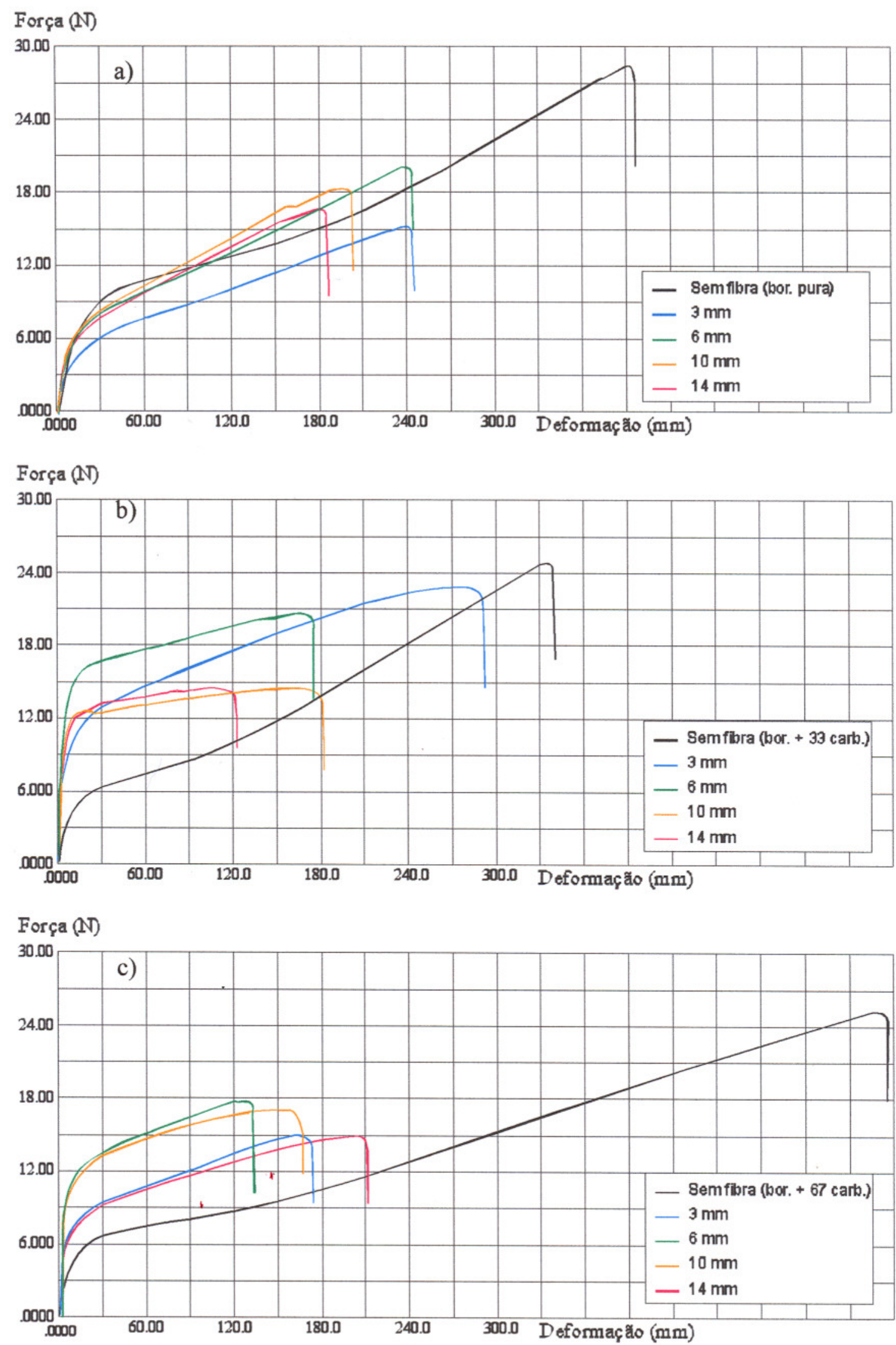

Figura 16: Curvas obtidas em ensaios de tração. Estudo da variação do tamanho de fibra lavada sobre matriz de (a) borracha pura, (b) borracha com 33 pcr de carbonato, e (c) borracha com 67 pcr de carbonato. Mantido o teor de fibra em 22 pcr. 


\subsection{3 - Efeito do Tratamento da Fibra de Sisal nos Compósitos}

Visando otimizar-se o reforço das matrizes de borracha com fibras de sisal com tamanho de $6 \mathrm{~mm}$, passou-se a investigar o efeito do tratamento empregado nas fibras nas propriedades dos compósitos. Os estudos descritos até este item consideraram fibras lavadas em água a $80^{\circ} \mathrm{C}$, por um período de $1 \mathrm{~h}$.

Nesta etapa, além das fibras lavadas em água quente, trabalhou-se com fibras de sisal sem qualquer tipo de tratamento, e com fibras mercerizadas em solução de $\mathrm{NaOH}$ a $10 \%$ por um período de $3 \mathrm{~h}$ à temperatura ambiente; conforme definido previamente no item 5.1.

A Figura 17 apresenta o comportamento para cada uma das propriedades mecânicas investigadas em função destes tratamentos das fibras. No que se refere à elongação na ruptura, numa primeira análise percebe-se que, qualquer que seja o tipo de fibra empregada ocorre uma acentuada redução na elongação de cada um dos compósitos. Observando-se isoladamente o comportamento para cada tipo de matriz (borracha pura, borracha com 33 pcr de carbonato e borracha com 67 pcr de carbonato) pode-se dizer que os tratamentos não levam a efeitos muito diferentes no grau de elongação.

Observa-se também uma confirmação do comportamento verificado no estudo anterior, de que a elongação cai a niveis discretamente inferiores quando o carbonato está associado ao compósito, sendo seu efeito mais pronunciado quando seu teor é mais elevado.

Quanto à tensão na ruptura, existe uma tendência de aumento na mesma à medida que aumenta o teor de carbonato de cálcio associado à matriz de borracha.

No entanto, para a propriedade de tensão na ruptura já se percebe uma diferença maior em função do tratamento empregado na fibra. Nota-se que a fibra 

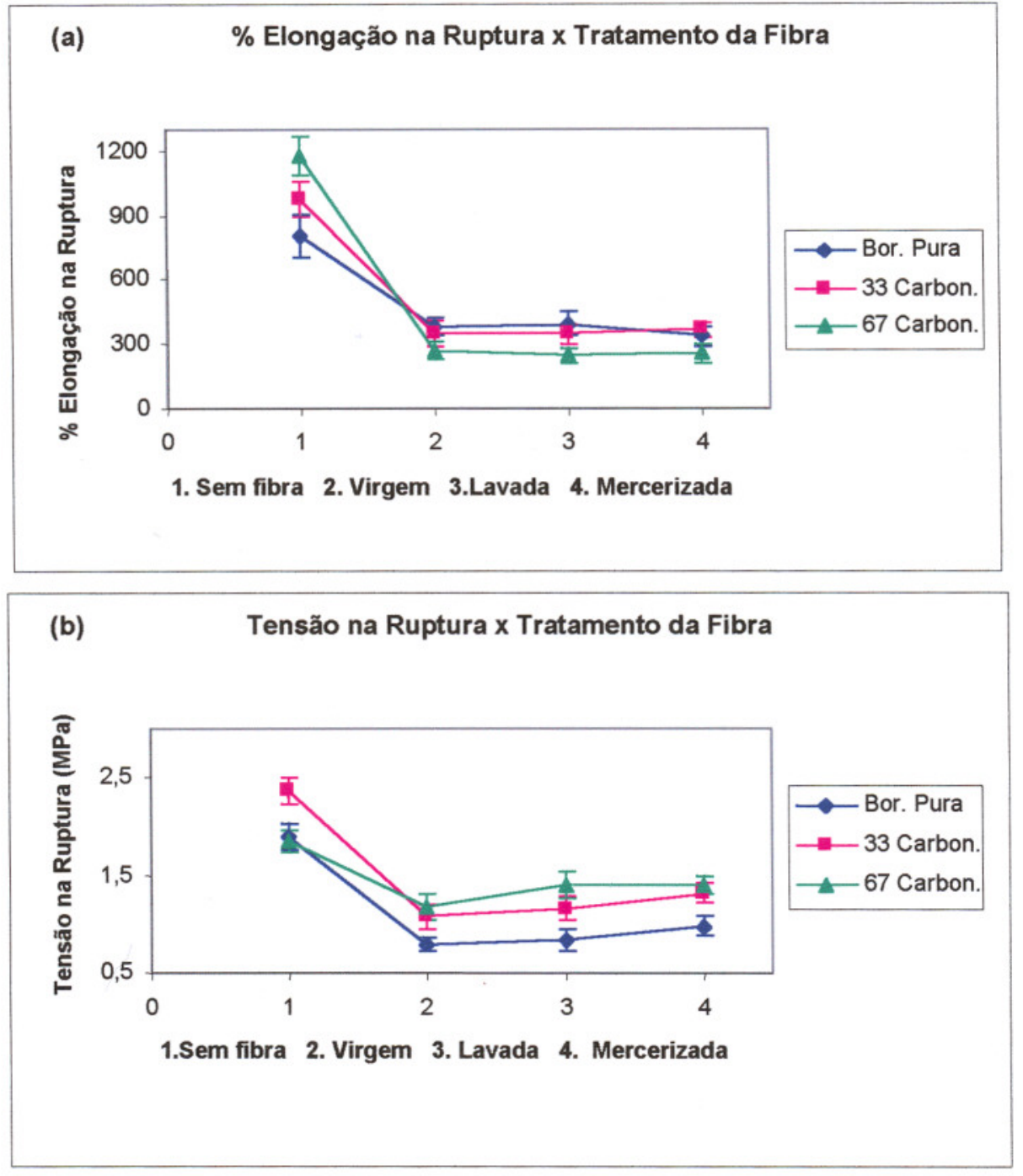

(c)

Módulo de Elasticidade a $10 \%$ x Tratamento da Fibra

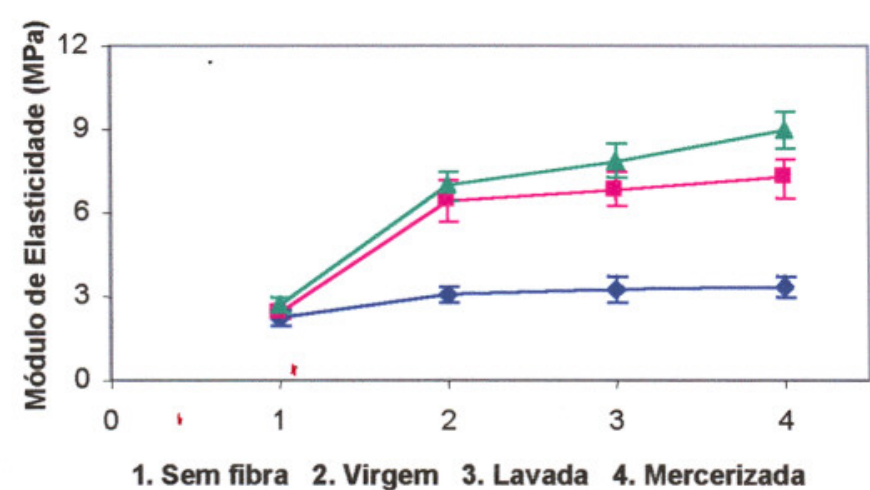

$\longrightarrow$ Bor. Pura - 33 Carbon. -467 Carbon.

Figura 17: Curvas de (a) \% de elongação na ruptura, (b) Tensão na ruptura e (c) Módulo de elasticidade a $10 \%$ de elongação, para o estudo da variação do tipo de tratamento da fibra de sisal, sobre borracha nitrílica pura; borracha nitrílica com 33 pcr de carbonato; e borracha nitrílica com 67 pcr de carbonato. 
sem tratamento tende a apresentar os menores resultados, qualquer que seja a matriz empregada. A fibra lavada eleva suavemente os valores de tensão em relação aos obtidos com fibra sem tratamento, independente da matriz; e o uso de fibra mercerizada apresenta um efeito discretamente mais pronunciado, elevando a tensão a patamares na faixa de $20 \%$ acima do encontrado com a fibra sem tratamento.

Quanto ao módulo, repete-se o comportamento encontrado para a tensão na ruptura; ou seja, a fibra lavada leva a resultados um pouco superiores aos encontrados para a fibra sem tratamento, e a fibra mercerizada tende a sobrepor-se à fibra lavada.

O que se observa nitidamente no gráfico do módulo da Figura 17 é o aumento provocado pela presença de carbonato nos compósitos. A presença de 33 per de carbonato eleva os valores de módulo a uma faixa $100 \%$ superior aos obtidos nas correspondentes formulações de borracha com fibra sem tratamento, fibra lavada e fibra mercerizada. Este percentual torna-se ainda mais elevado quando se emprega 67 pcr de carbonato.

Outra maneira que esta análise pode ser feita é pegando-se, por exemplo, os resultados médios de módulo de elasticidade a $10 \%$, obtidos com as formulações com 33 pcr de carbonato de cálcio e 22 pcr de fibras de sisal mercerizado:

- Borracha nitrílica pura $=2,27 \mathrm{Mpa}$.

- Borracha com 33 pcr de carbonato de cálcio = 2,41 MPa (aumento de 6,2\% em relação à matriz de borracha pura).

- Borracha com 22 per de fibras de sisal mercerizado = 3,36 MPa (aumento de $48 \%$ em relação à matriz de borracha pura).

- Borracha com 33 pcr de carbonato e 22 pcr de fibras de sisal mercerizado $=7,28$ $\mathrm{MPa}$ (aumento de $220 \%$ em relação à matriz de borracha pura). 
Ou seja, percebe-se nitidamente que o uso combinado de carbonato de cálcio com fibras de sisal como reforço para a matriz de borracha nitrílica, potencializa o módulo de elasticidade do compósito, levando a resultados bastante superiores aos obtidos pelas contribuições individuais de cada uma das cargas (aumento de $220 \%$ em relação à borracha pura para o compósito onde o carbonato de cálcio e fibras de sisal estão associados, contra $54,2 \%$ para a somatória das contribuições individuais de cada uma destas mesmas cargas).

Neste estudo observou-se que ganhos foram obtidos com o tratamento de mercerização nas fibras. Este comportamento está de acordo com o encontrado em diversos trabalhos anteriores. A literatura $[3,17,41]$ explica que isto é devido ao fato de que o tratamento alcalino melhora as características de adesão da superfície da fibra através da remoção de impurezas naturais e artificiais, produzindo uma topografia superficial rugosa. Além disso, o tratamento alcalino conduz à desfibrilação das fibras, ou seja, a separação do feixe de fibras em fibras menores (fibrilas). Isto aumenta a área superficial efetiva disponível para contato com a matriz. Em outras palavras, o tratamento alcalino reduz o diâmetro do feixe de fibras, e deste modo aumenta a razão de aspecto. Conseqüentemente, o desenvolvimento de uma topografia superficial rugosa e a intensificação da razão de aspecto propiciam melhor adesão da interface fibra-matriz e um aumento nas propriedades mecânicas. A imagem por MEV apresentada no item 5.1 comprova as alterações provocadas na superficie da fibra de sisal com o tratamento de mercerização.

Os resultados obtidos revelam ainda o grande ganho nas propriedades mecânicas quando o carbonato está associado ao compósito. Em função destes resultados, o estudo de variação do teor de fibra nos compósitos foi efetuado com 
fibra mercerizada, sendo as matrizes de borracha pura e borracha com $67 \mathrm{pcr}$ de carbonato.

A Figura 18 mostra um conjunto de curvas representativas de Força $(\mathrm{N})$ em função da deformação (mm) obtido nestas avaliações. Conforme explicado no item 4.2.5.2, existem diferenças de espessuras entre os corpos de prova provenientes de formulações diferentes, as quais são levadas em consideração nos cálculos dos valores de tensão de ruptura e módulo de elasticidade a $10 \%$ de elongação. No Anexo $\mathrm{C}$ encontram-se os resultados médios encontrados para as propriedades mecânicas. 


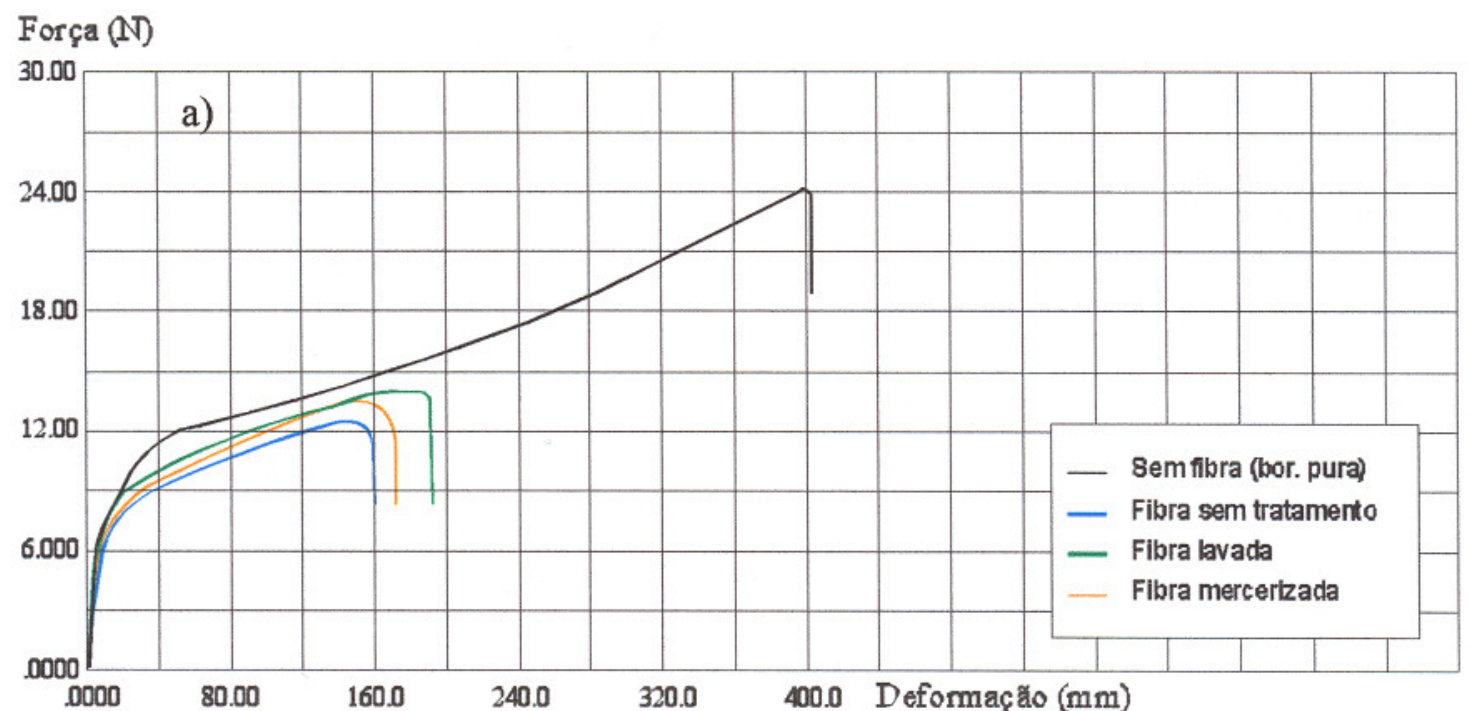

Força (N)

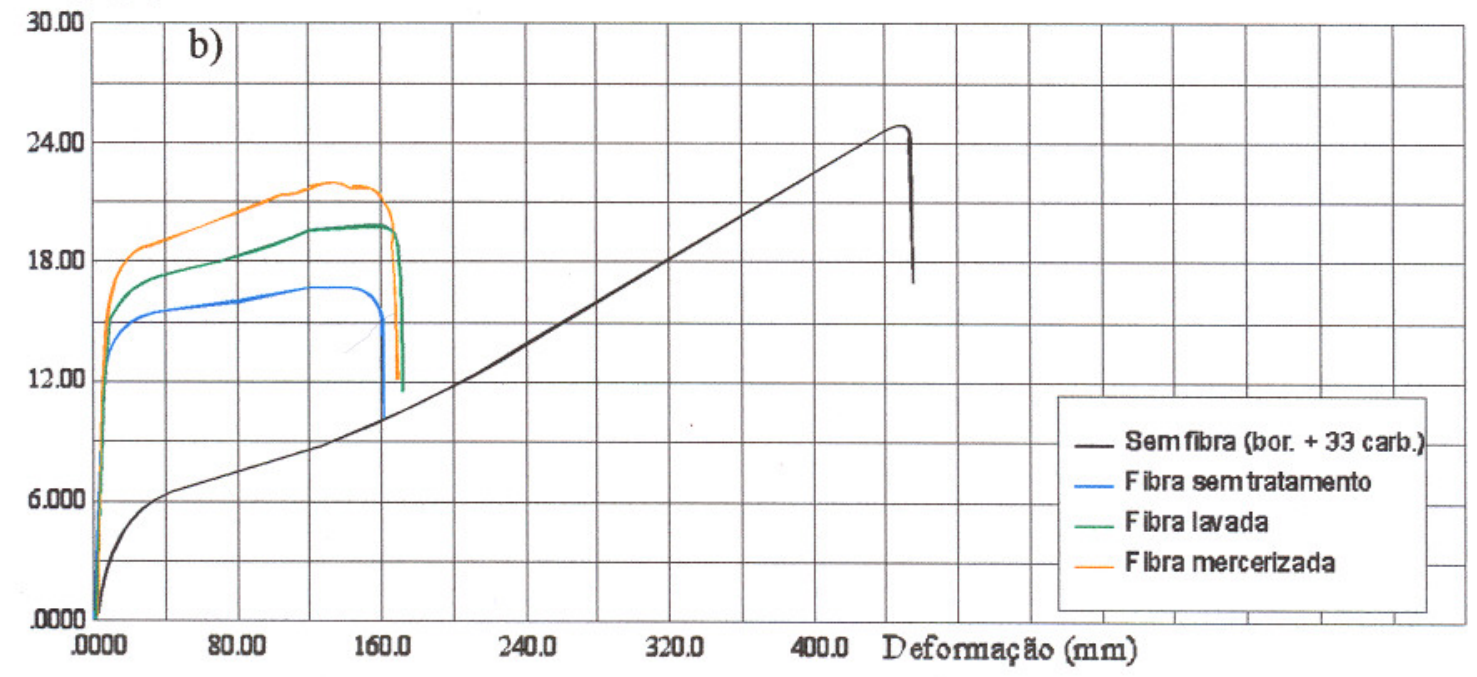

Força (N)

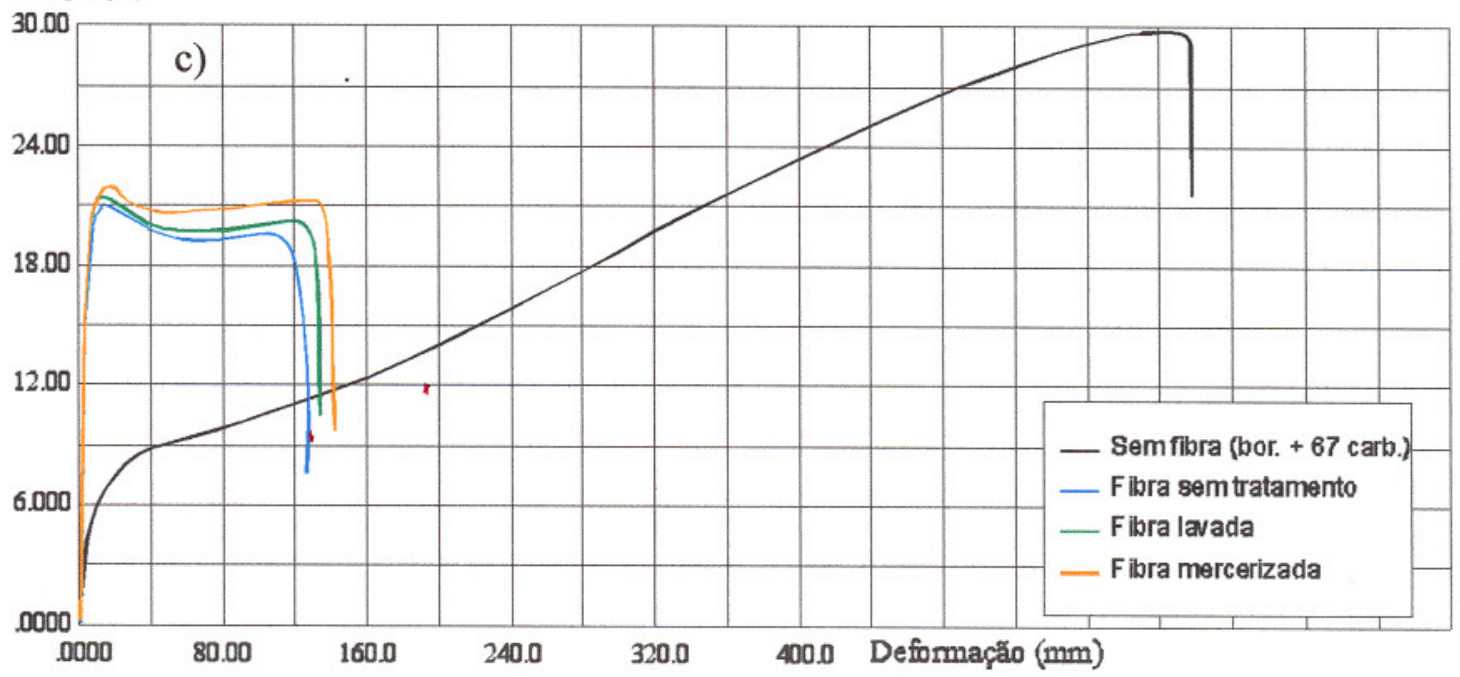

Figura 18: Curvas obtidas em ensaios de tração. Efeito do tipo de tratamento da fibra sobre matriz de (a) borracha pura, (b) borracha com 33 pcr de carbonato, e (c) borracha com 67 per de carbonato. Mantido teor de fibra em $22 \mathrm{pcr}$, tamanho $6 \mathrm{~mm}$. 


\subsection{4 - Efeito do Teor de Fibra de Sisal Mercerizado nos Compósitos}

Nesta última etapa de estudos referente à análise das propriedades mecânicas dos compósitos, variou-se o teor de fibras de sisal mercerizadas sobre matriz de borracha nitrílica pura e borracha com 67 pcr de carbonato de cálcio. $\mathrm{O}$ teor de fibras foi explorado na faixa de 0 a 44 pcr.

A Figura 19 mostra as curvas referentes aos valores médios encontrados para as propriedades mecânicas. No primeiro gráfico observa-se que à medida que se incrementa o teor de fibras de sisal, ocorre uma redução na elongação do compósito. Como já observado em estudos anteriores, a matriz com carbonato de cálcio apresenta uma queda mais acentuada nos valores de elongação do que aquela observada na matriz de borracha pura.

A curva de tensão na ruptura apresenta um comportamento diferenciado para cada tipo de matriz. No caso da matriz de borracha pura existe um decaimento crescente na medida em que se aumenta o teor de fibras. Na matriz de borracha com 67 pcr de carbonato observa-se que à medida que se começa a adicionar as fibras de sisal a tensão tende a decair até o teor de 11 pcr de fibras; ponto a partir do qual começa a haver uma inversão na curva chegando-se a atingir com o teor de 44 pcr um valor de tensão equivalente ao obtido para a mesma matriz sem fibras.

O efeito de cargas fibrosas na resistência à tensão de ruptura de compósitos de borracha reforçados com fibras curtas tem sido amplamente estudado. Geethamma e colaboradores [67] relatam que geralmente a resistência à tensão cai inicialmente até uma certa quantidade de fibra a partir da qual passa a aumentar. Este volume mínimo de fibra é conhecido como volume crítico, acima do qual a fibra reforça a matriz. $\mathrm{O}$ volume crítico varia com a natureza da fibra e da matriz, com a razão de aspecto da fibra, com a adesão interfacial fibra/matriz, etc. Mencionam ainda como 

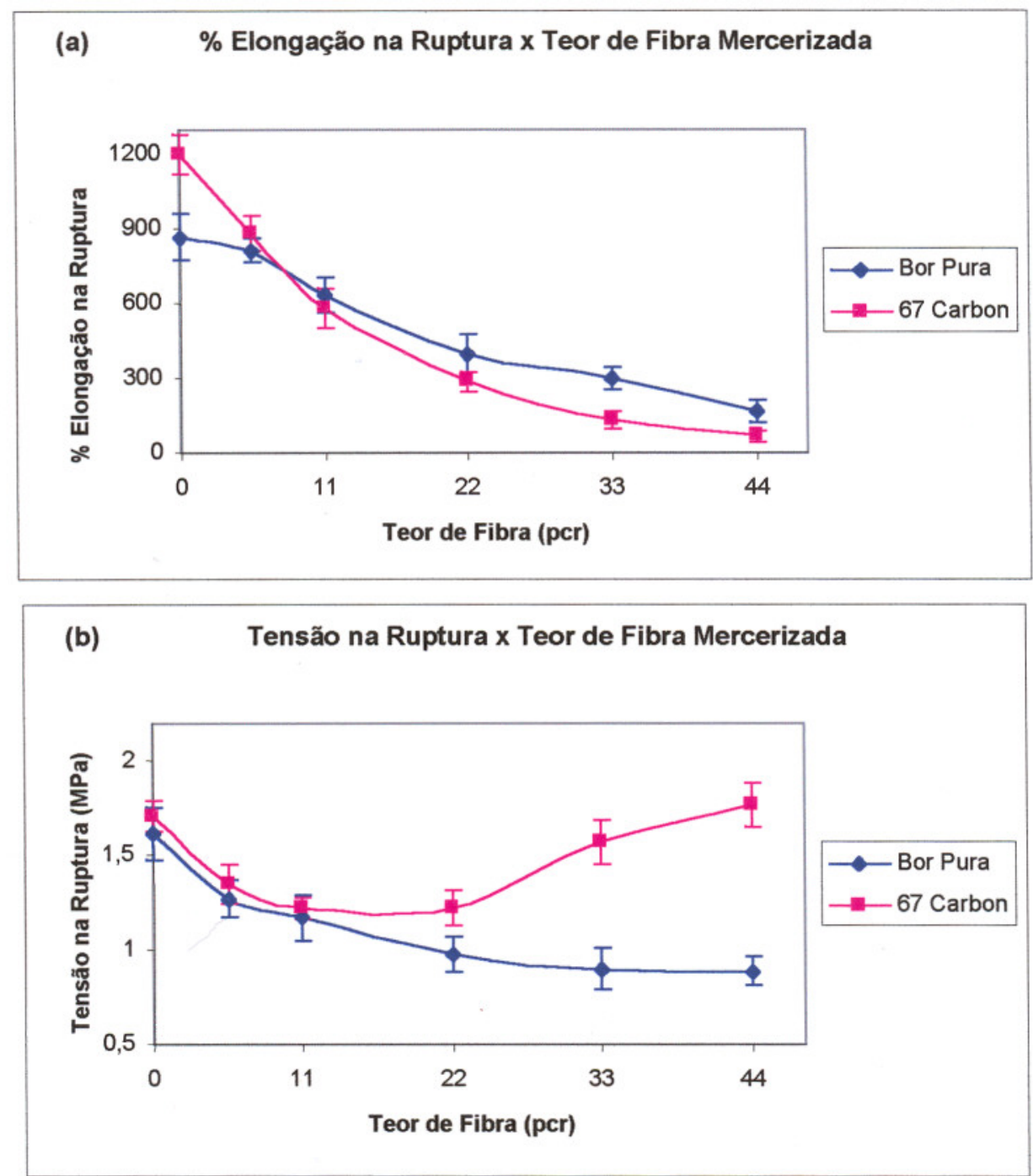

(c) Módulo de Elasticidade a $10 \%$ x Teor de Fibra Mercerizada

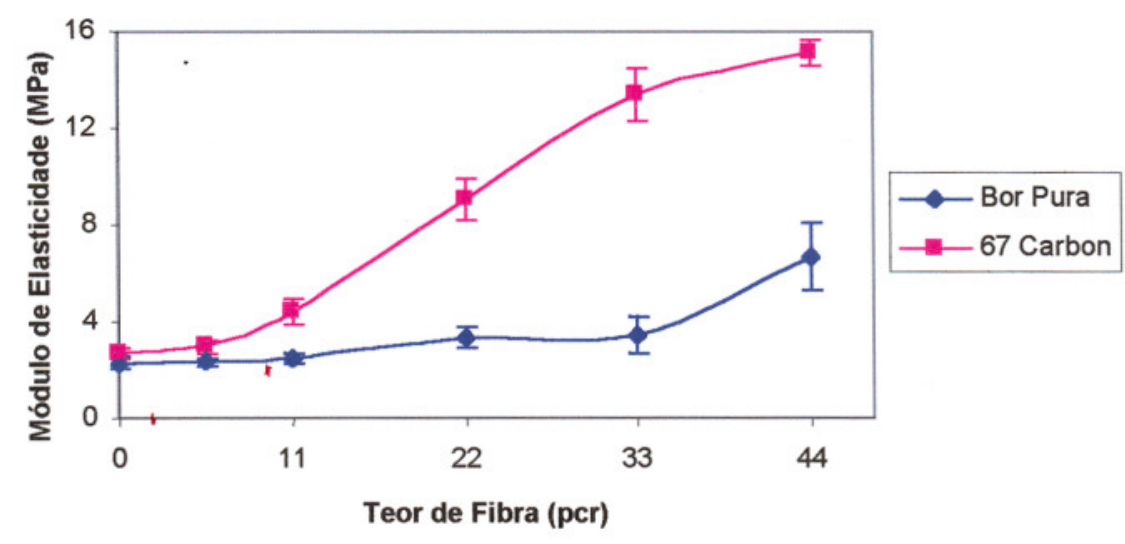

Figura 19: Curvas de (a) \% de elongação na ruptura, (b) Tensão na ruptura e (c) Módulo de elasticidade a $10 \%$ de elongação, para o estudo da variação do teor da fibra de sisal mercerizado $(\mathrm{NaOH} 10 \%, 3 \mathrm{~h}, \mathrm{~T}$ ambiente), sobre borracha nitrílica pura e borracha nitrílica com 67 pcr de carbonato. Fibras com $6 \mathrm{~mm}$ de comprimento. 
exemplo que em matrizes de borracha foi encontrado que a carga crítica para fibras de juta é de 40 pcr, e de 7,5 pcr para fibras de seda. Em nosso sistema de estudos observa-se que a carga crítica é de 11 pcr, sendo que a adição de cerca de 33 a 44 pcr de fibra leva à obtenção de um compósito com a mesma tensão de ruptura apresentada pela matriz sem adição da carga de fibras de sisal.

Em relação ao módulo a 10\% observa-se que na matriz de borracha pura esta propriedade pouco se altera à medida que se aumenta o teor de fibras até 11 pcr. Este valor tem uma certa similaridade com os trabalhos de Joseph e colaboradores [37], que em um trabalho com borracha natural, identificaram que apenas acima de $10 \mathrm{pcr}$ o sisal reforça tal matriz. A partir de 11 pcr, verifica-se que o módulo tende a aumentar discretamente, apresentando um incremento elevado para o teor de $44 \mathrm{pcr}$ de fibras de sisal. Já para a matriz de borracha com 67 pcr de carbonato, o efeito de aumento no módulo se pronuncia bem antecipadamente, iniciando a partir de 5,5 pcr.

Repetindo-se a análise feita no estudo anterior quanto às contribuições individuais e em combinação do carbonato de cálcio e fibras de sisal para a propriedade de módulo de elasticidade, observou-se que para a combinação de um teor de 33 pcr de fibras mercerizadas com 67 pcr de carbonato, o módulo obtido foi de $13,43 \mathrm{MPa}$ (486\% superior ao encontrado para a borracha pura), contra uma somatória das contribuições individuais de $98 \%$ de aumento frente ao obtido para a borracha pura ( $51 \%$ proveniente da composição com carbonato, e $47 \%$ proveniente da combinação com fibras de sisal mercerizado); reproduzindo desta maneira, o efeito potencializado da combinação das cargas como reforço para o compósito.

A Figura 20 exibe um conjunto de curvas características representativas de Força $(\mathrm{N})$ em função da deformação $(\mathrm{mm})$, obtido nestas avaliações. Conforme explicado no item 4.2.5.2, existem diferenças de espessuras entre os corpos de prova 
provenientes de formulações diferentes, as quais são levadas em consideração nos cálculos dos valores de tensão de ruptura e módulo de elasticidade a $10 \%$ de elongação. No Anexo D encontram-se os resultados médios das propriedades mecânicas encontradas.
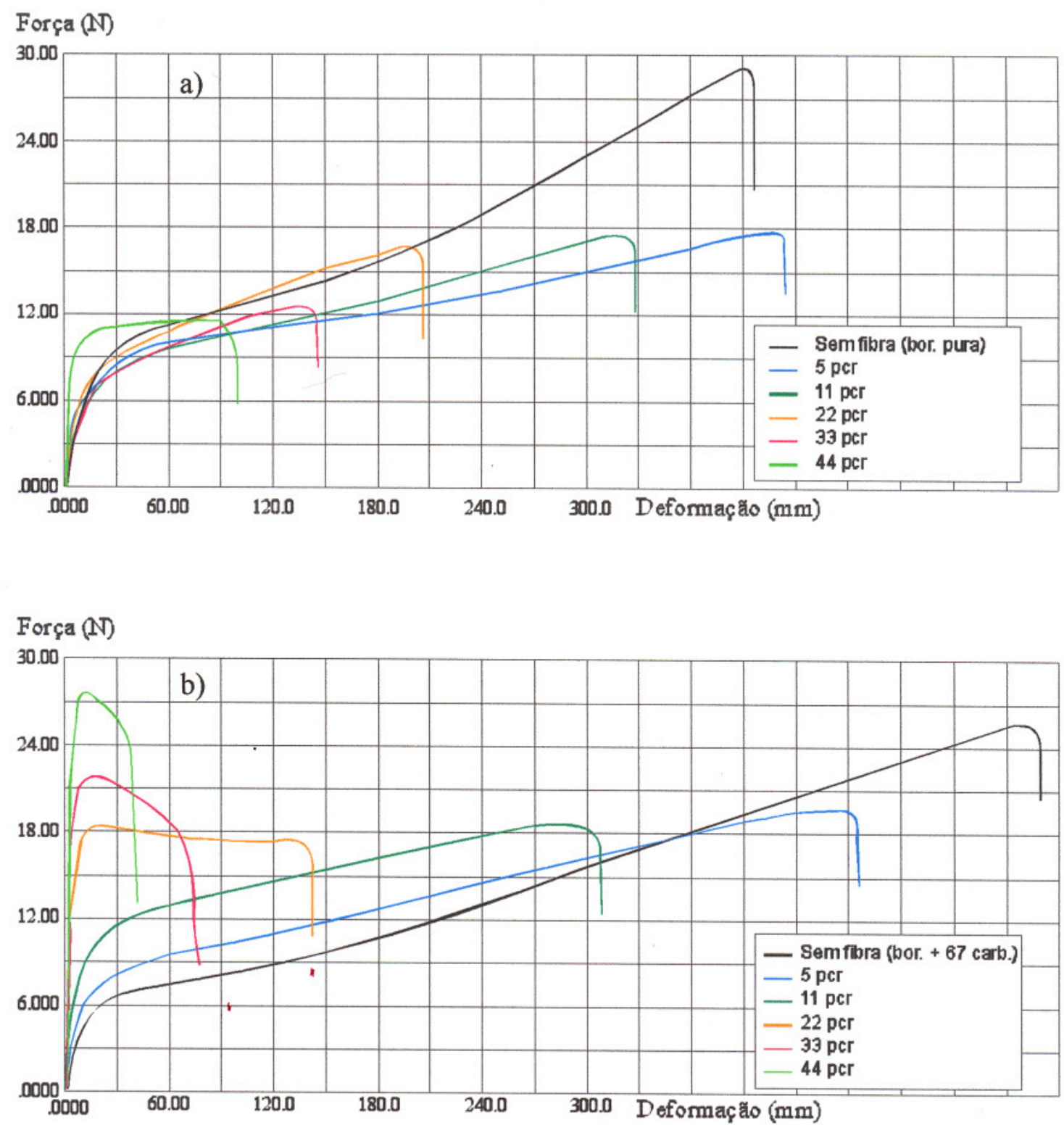

Figura 20: Curvas obtidas em ensaios de tração. Efeito do teor de fibra mercerizada sobre matriz de (a) borracha pura e, (b) borracha com 67 pcr de carbonato. Mantido o tamanho de fibra em $6 \mathrm{~mm}$ para as duas situações. 


\section{4 - Microscopia Eletrônica de Varredura dos Compósitos de Borracha Nitrilica com Fibras de Sisal}

Com o objetivo de se verificar a interação entre fibra /matriz realizou-se análise por MEV da superficie de fratura dos compósitos de borracha nitrílica com fibras de sisal sem tratamento, fibras de sisal lavadas em água a $80^{\circ} \mathrm{C}$ por $1 \mathrm{~h}$, e fibras de sisal mercerizadas. Analisou-se também a interação da borracha com carbonato de cálcio, na presença e ausência de fibras de sisal mercerizadas. As Figuras 21-25 mostram fotos representativas destas análises.

Nas Figuras 21-23 pode-se observar que a molhabilidade da fibra de sisal mercerizada pela matriz de borracha é discretamente superior à da fibra de sisal lavada, sendo ambas superiores à molhabilidade apresentada para a fibra de sisal sem tratamento; comportamentos estes que justificam as explicações dadas aos resultados mecânicos encontrados no estudo relatado no item 5.3.3.

As Figuras 24-25 mostram a boa interação do carbonato de cálcio com a matriz de borracha, bem como a não-interferência na interação fibra/matriz, mostrando que na verdade para esta matriz estudada o carbonato não funciona apenas como uma carga para barateamento do compósito como normalmente é mencionado na literatura [2], mas sim como uma carga de reforço, justificando o comportamento encontrado na melhoria de algumas propriedades mecânicas do compósito borracha/sisal mercerizado quando o mesmo está presente (item 5.3.4). 


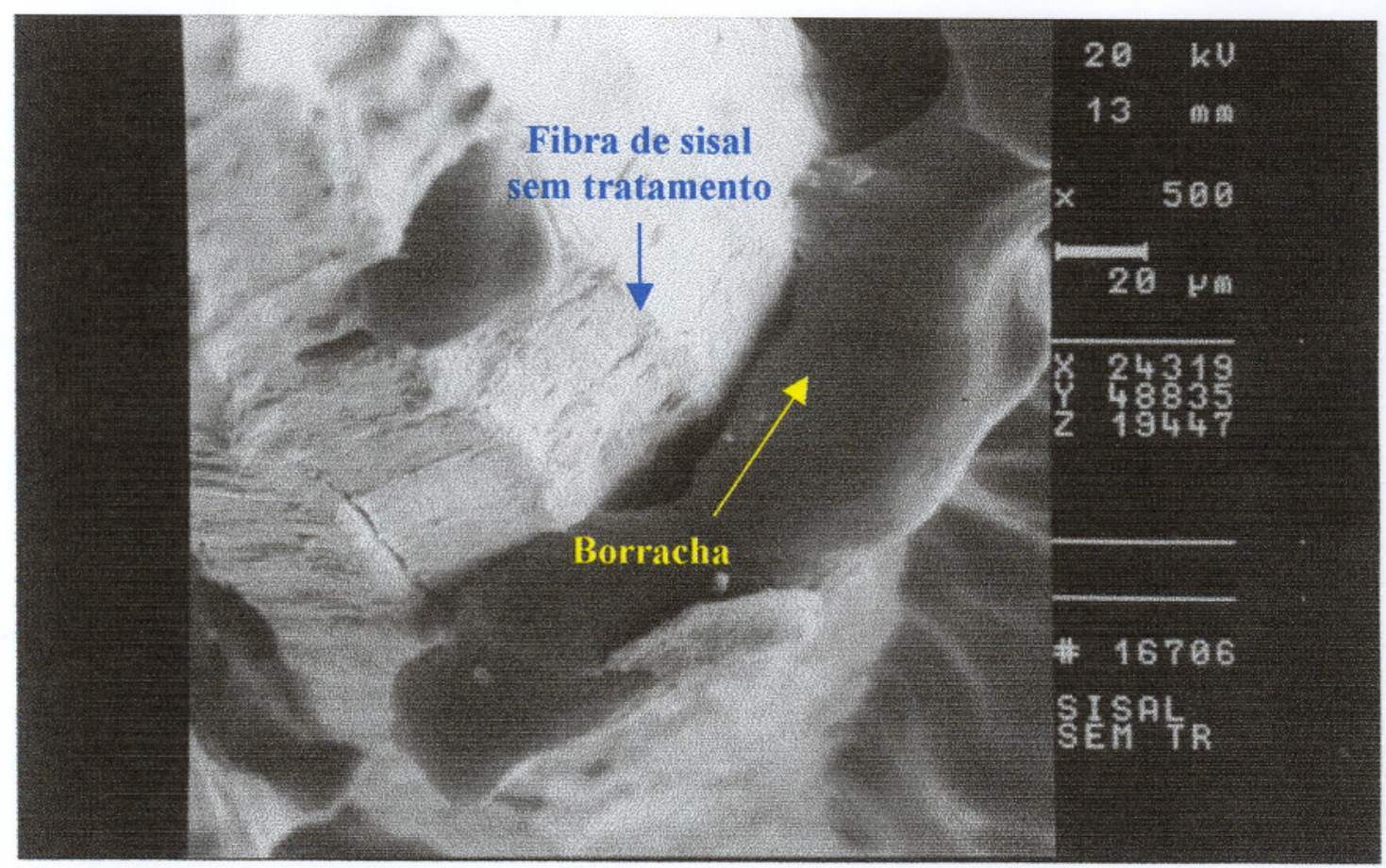

Figura 21: Micrografia obtida por MEV da superficie de fratura de compósitos de borracha nitrílica com fibras de sisal sem tratamento. Ampliação de 500 vezes.

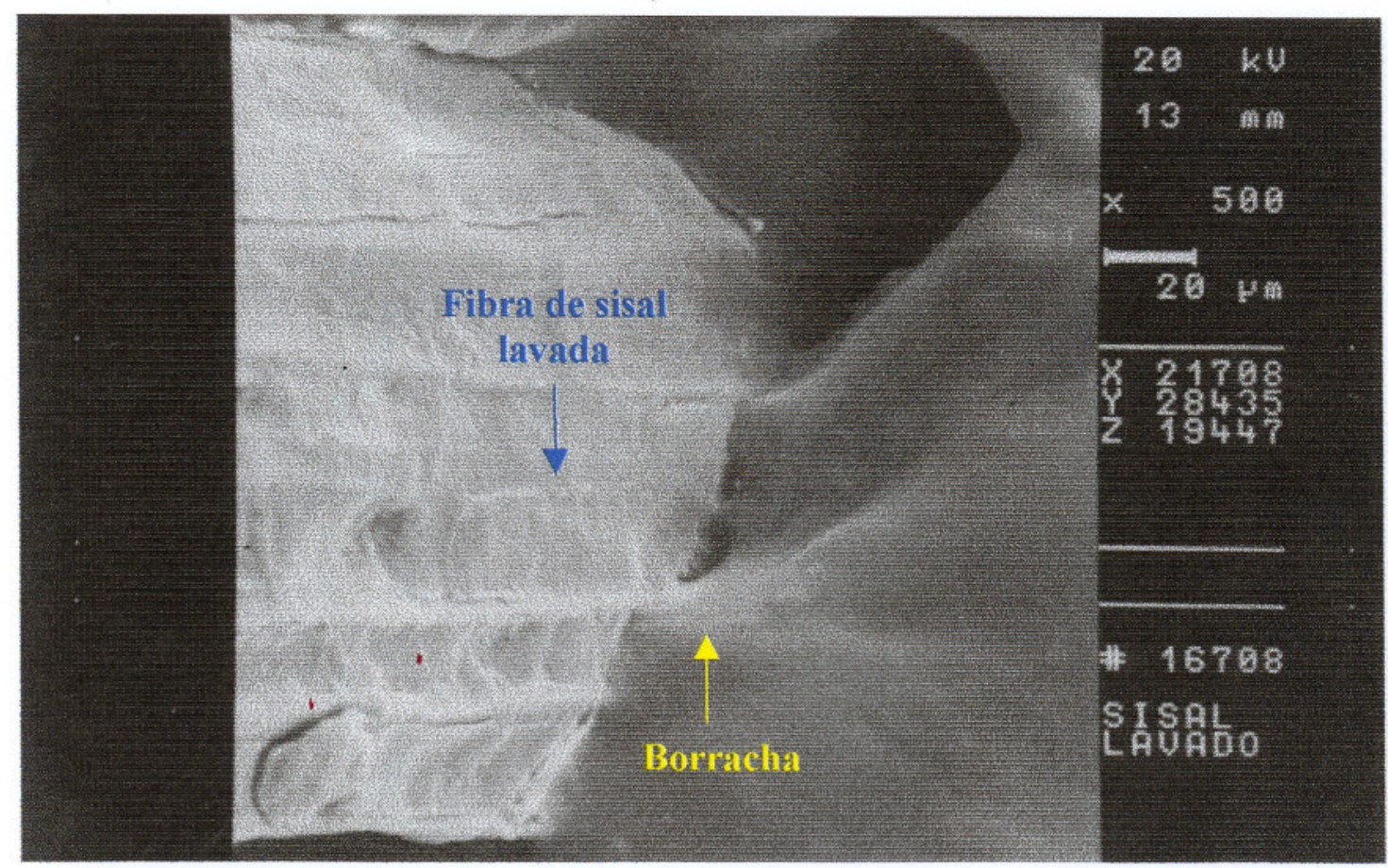

Figura 22: Micrografia obtida por MEV da superficie de fratura de compósitos de borracha nitrílica com fibras de sisal lavadas em água quente. Ampliação de 500 vezes. 


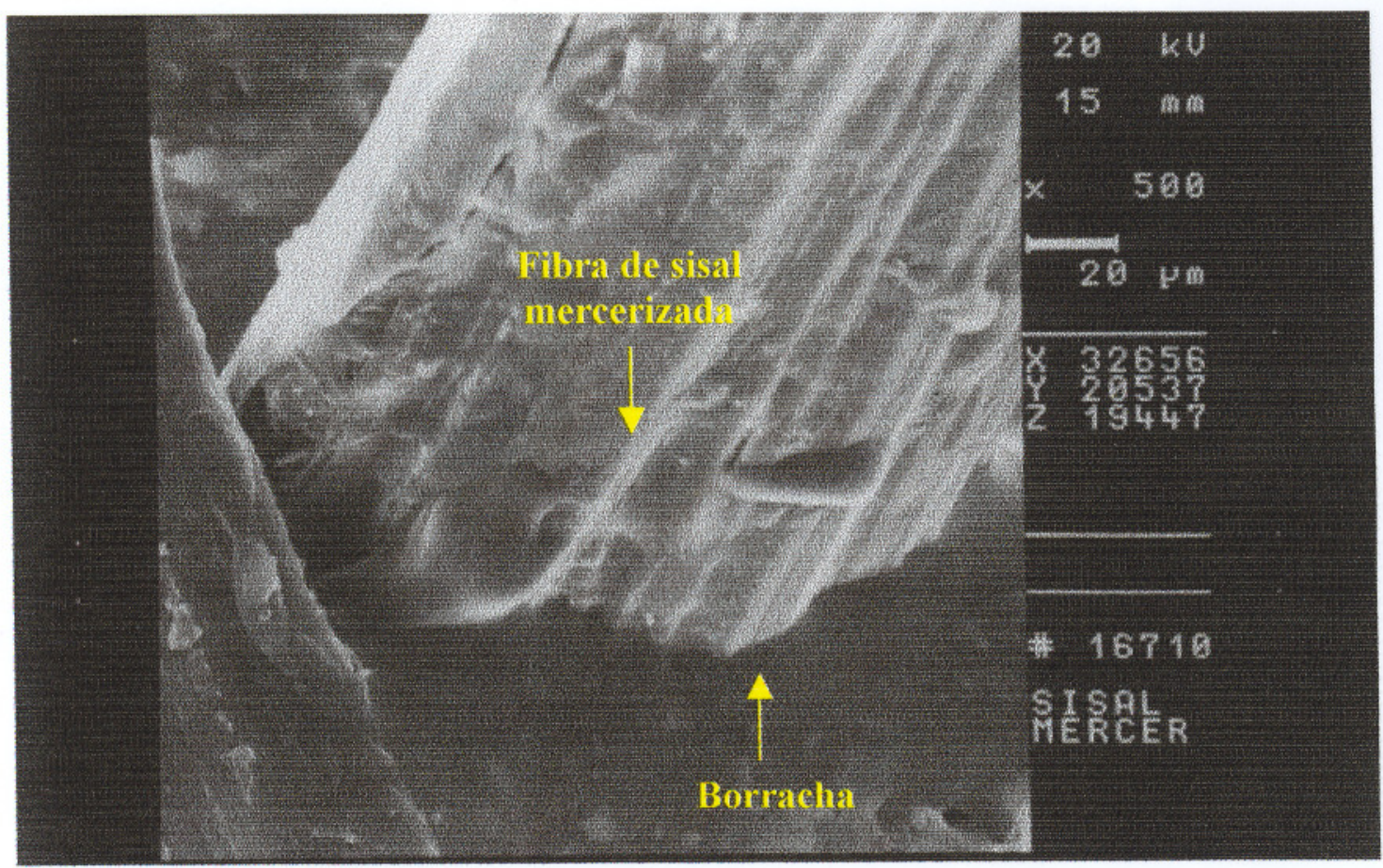

Figura 23: Micrografia obtida por MEV da superfície de fratura de compósitos de borracha nitrílica com fibras de sisal mercerizadas. Ampliação de 500 vezes.

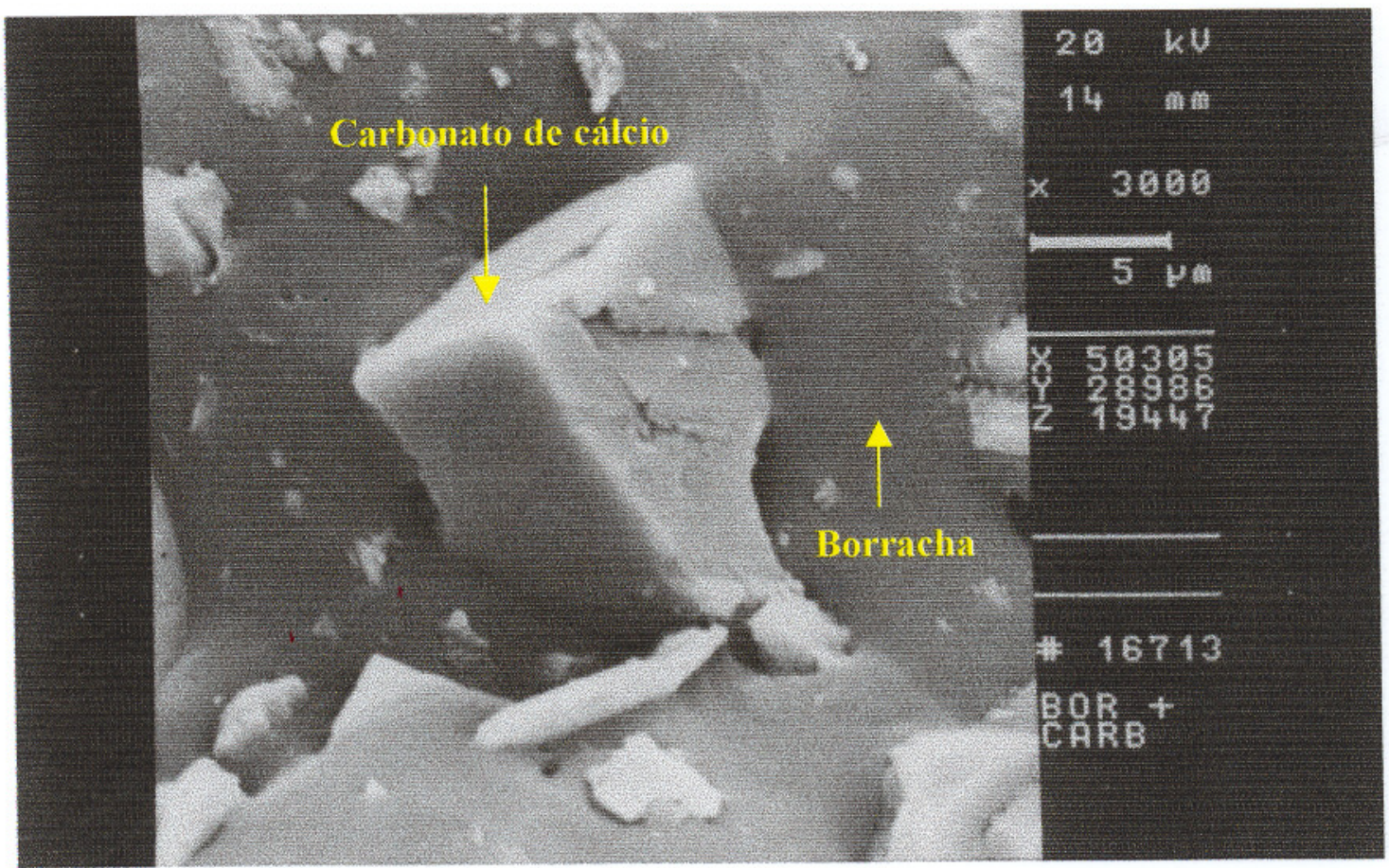

Figura 24: Micrografia obtida por MEV da superficie de fratura de compósitos de borracha nitrílica com carbonato de cálcio. Ampliação de 3.000 vezes. 


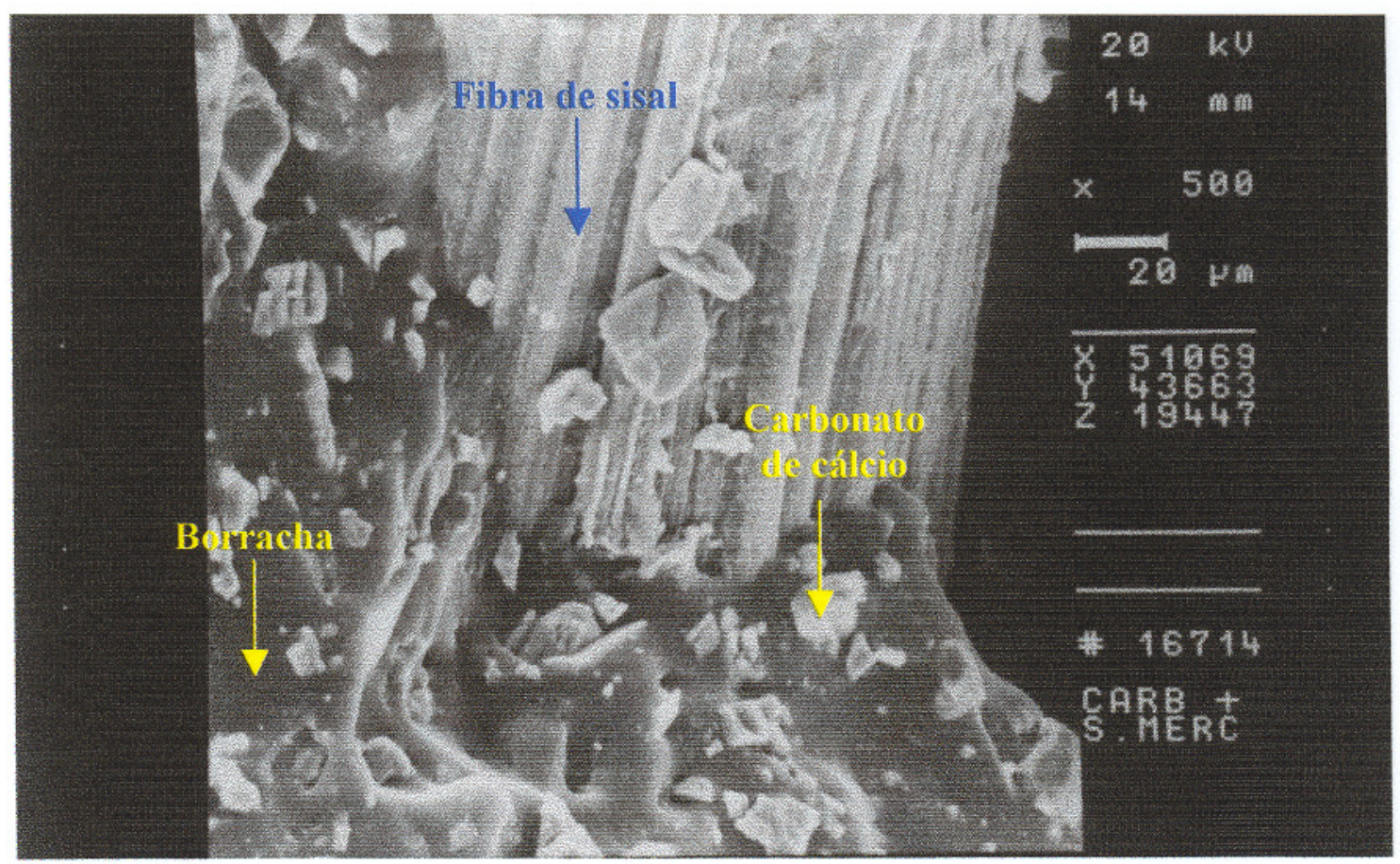

Figura 25: Micrografia obtida por MEV da superfície de fratura de compósitos de borracha nitrílica com carbonato de cálcio e fibras de sisal mercerizadas. Ampliação de 500 vezes.

\section{5 - Análise Térmica dos Compósitos}

A análise termogravimétrica foi realizada para se avaliar o comportamento térmico dos compósitos obtidos. Na Tabela III encontram-se as formulações dos compósitos usados nas análises térmicas, tanto de TG quanto de DSC.

Tabela III: Formulações,empregadas nas análises térmicas de TG e DSC.

\begin{tabular}{|l|c|c|c|c|}
\hline \multirow{2}{*}{ Componente } & \multicolumn{4}{|c|}{ Formulações em pcr } \\
\cline { 2 - 5 } & F1 & F2 & F3 & F4 \\
\hline Borracha & 100 & 100 & 100 & 100 \\
\hline Estabilizante & 1 & 1 & 1 & 1 \\
\hline Fibra Merc. & - & 22 & - & 22 \\
\hline Carbonato & - & - & 67 & 67 \\
\hline
\end{tabular}

\begin{tabular}{|c|c|c|c|}
\hline \multicolumn{4}{|c|}{ Formulações em \% } \\
\hline F1 & F2 & F3 & F4 \\
\hline 99,01 & 81,30 & 59,52 & 52,63 \\
\hline 0,99 & 0,81 & 0,60 & 0,53 \\
\hline- & 17,89 & - & 11,58 \\
\hline- & - & 39,88 & 35,26 \\
\hline
\end{tabular}


A Figura 26 mostra o conjunto das curvas em sobreposição, obtidas nas análises de TG para as quatro formulações mencionadas na Tabela III. Nas Figuras 27-30 os resultados são mostrados individualmente, correspondendo respectivamente à borracha nitrilica pura; borracha nitrílica com carbonato de cálcio; borracha nitrílica com fibras de sisal mercerizadas; e borracha nitrílica com fibras de sisal mercerizadas e carbonato de cálcio.

A visão do conjunto de curvas em sobreposição da Figura 26, mostra que os compósitos que possuem fibras de sisal em sua composição apresentam uma etapa a mais de decomposição, e que os compósitos com carbonato de cálcio deixam teores de resíduos bem mais elevados na temperatura final de $600^{\circ} \mathrm{C}$.

Analisando os compostos individualmente, observa-se no gráfico da Figura 27 que a borracha nitrilica apresenta uma perda de massa de aproximadamente $2 \%$ até a temperatura de $220^{\circ} \mathrm{C}$. Esta perda vai se acentuando e em torno de $340^{\circ} \mathrm{C}$ começa a ocorrer a degradação estrutural da borracha nitrílica, que perde cerca de $50 \%$ de massa na temperatura de $442^{\circ} \mathrm{C}$. Próximo a $480^{\circ} \mathrm{C}$ a perda de massa passa a decair mais suavemente ocorrendo carbonização das amostras. Na temperatura de $600^{\circ} \mathrm{C}$, final da análise, o residuo é de aproximadamente $14 \%$.

O gráfico do compósito de borracha nitrílica com carbonato de cálcio exibido na Figura 28 apresenta um comportamento muito parecido com o da borracha pura, tendo como diferença básica o percentual de resíduo apresentado na temperatura final de $600^{\circ} \mathrm{C}$. A partir deste resíduo de $43 \%$ estima-se que a perda de massa proveniente do carbonato de cálcio é da ordem de $13 \%$, podendo estar aí incluída a perda proveniente de uma possível umidade absorvida pelo mineral no compósito, mostrando sua grande estabilidade térmica na faixa de temperatura investigada neste trabalho.

$$
\begin{gathered}
\text { IFSC-USP SERVICOO DE EIBLIOTECA } \\
\text { INFORMACAO }
\end{gathered}
$$




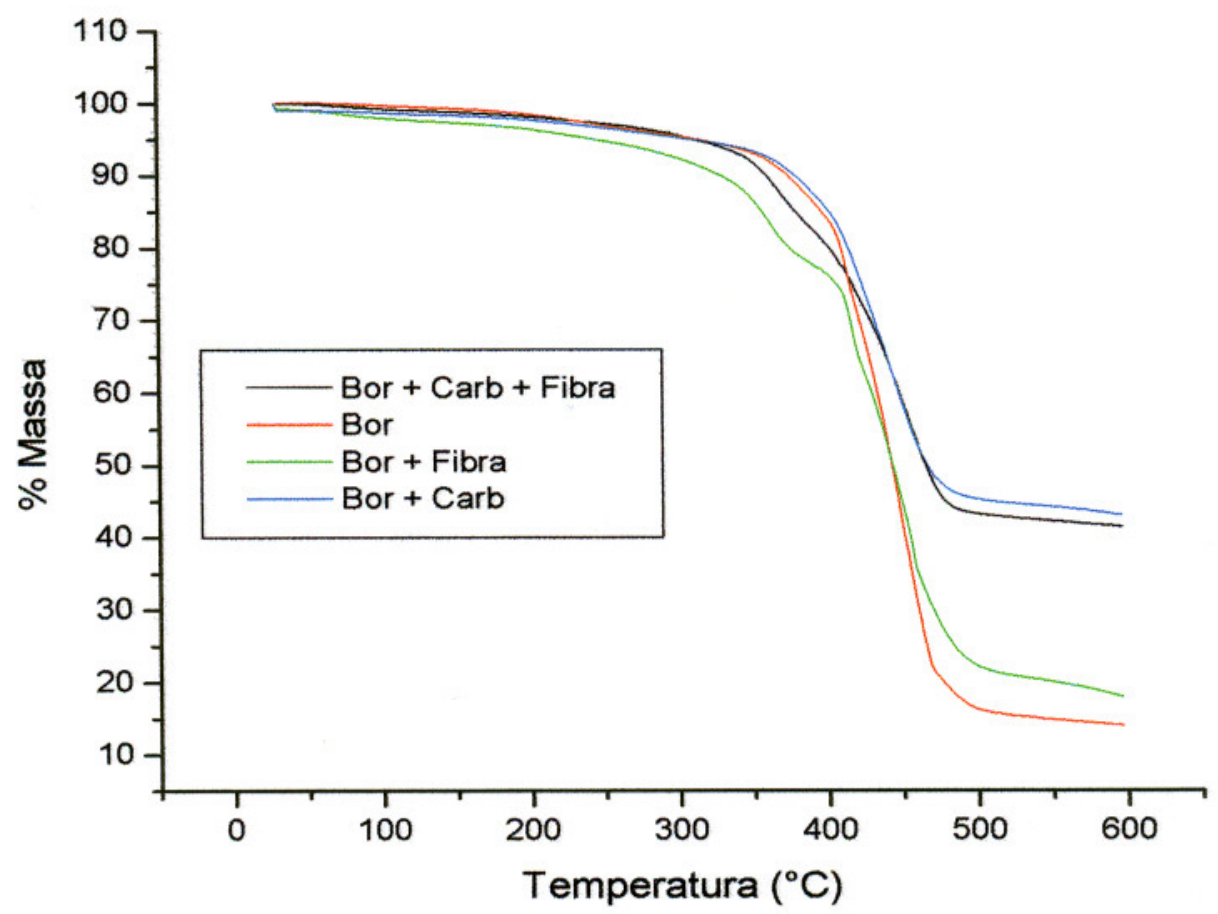

Figura 26: Curvas de TG para borracha nitrílica, e compósitos de borracha com carbonato, borracha com fibra de sisal, e borracha com fibra de sisal e carbonato. Taxa de aquecimento de $10^{\circ} \mathrm{C} / \mathrm{min}$, fluxo de $\mathrm{N}_{2}$ de $15 \mathrm{ml} / \mathrm{min}$.

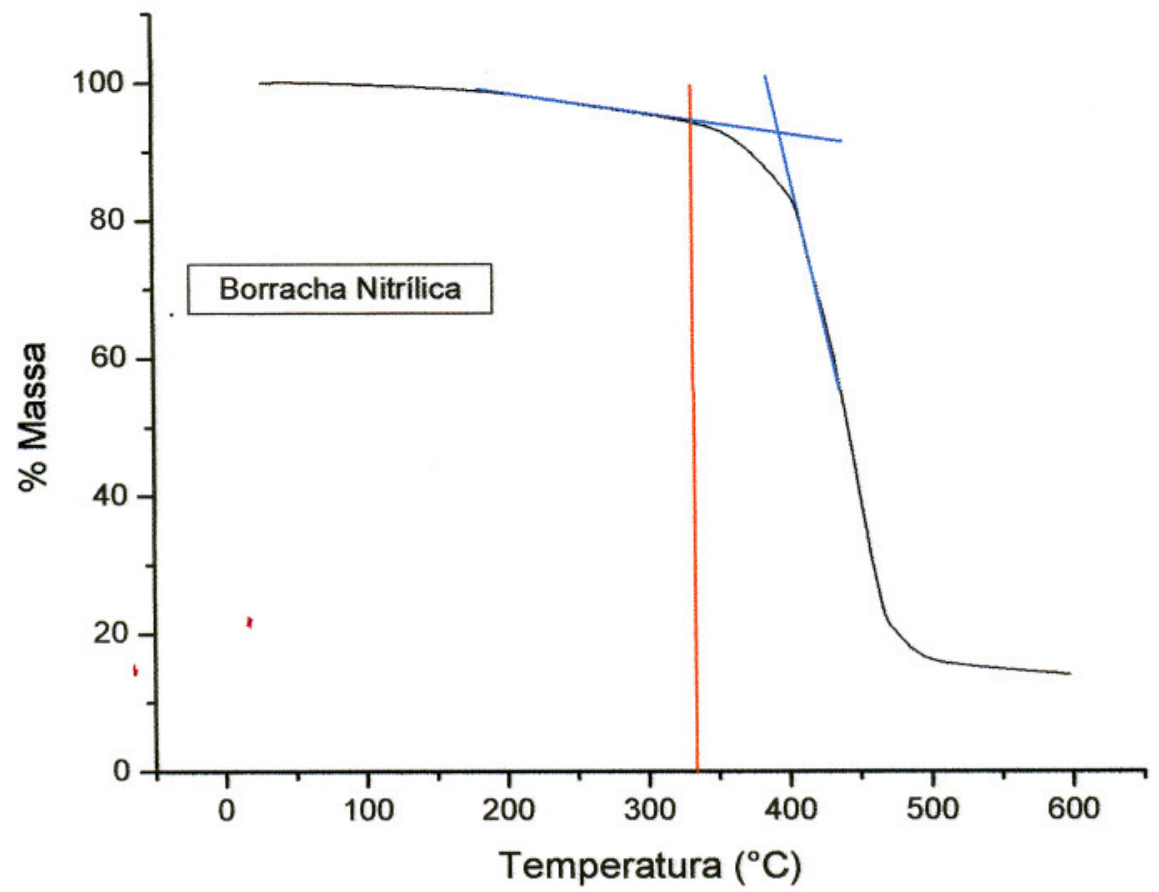

Figura 27: Curva de TG para borracha nitrílica. Taxa de aquecimento de $10^{\circ} \mathrm{C} / \mathrm{min}$, fluxo de $\mathrm{N}_{2}$ de $15 \mathrm{ml} / \mathrm{min}$. 


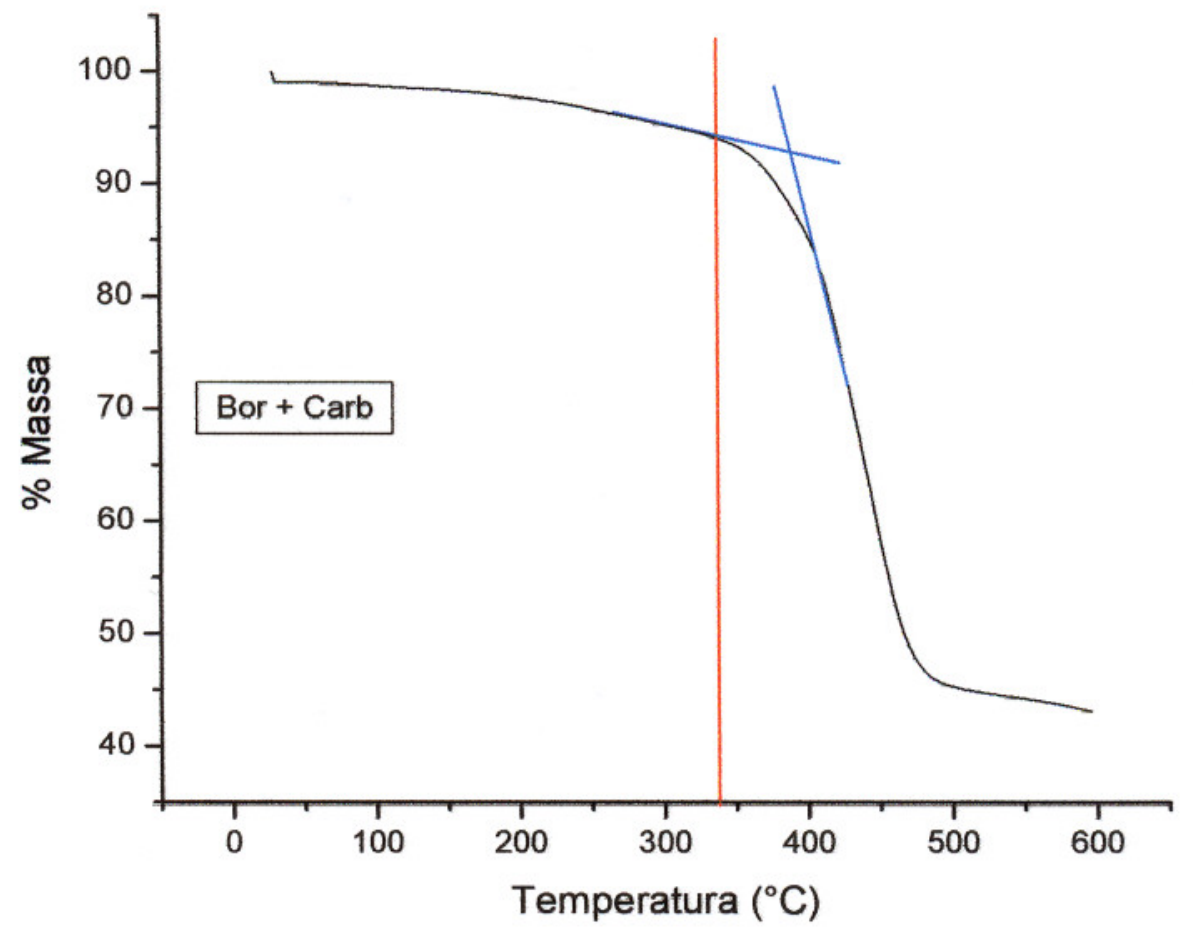

Figura 28: Curva de TG para o compósito de borracha nitrílica com carbonato de cálcio. Taxa de aquecimento de $10^{\circ} \mathrm{C} / \mathrm{min}$, fluxo de $\mathrm{N}_{2}$ de $15 \mathrm{ml} / \mathrm{min}$.

Analisando-se os gráficos das Figuras 29-30, as quais correspondem às formulações onde estão presentes fibras de sisal nos compósitos, verifica-se que ambos possuem duas etapas principais de decomposição. Da temperatura ambiente a $220^{\circ} \mathrm{C}$ existe uma perda de massa de aproximadamente $4 \%$. Este percentual passa a ficar em torno de $7,5 \%$ a $300^{\circ} \mathrm{C}$, temperatura a partir da qual acentua-se o primeiro estágio de decomposição, atribuído à degradação das fibras de sisal.

Pelo resíduo final da análise a $600^{\circ} \mathrm{C}$, obtido no gráfico da Figura 29 , e a partir da formuláção usada bem como do resultado de resíduo apresentado pela borracha nitrílica pura, pode-se estimar que as fibras de sisal, na maneira em que foram tratadas e submetidas neste experimento, apresentam uma perda de massa próxima a $65 \%$ ao atingir $600^{\circ} \mathrm{C}$. Este valor é dito estimado, pois nestes cálculos está sendo considerado que a amostra empregada na análise possui representatividade da 


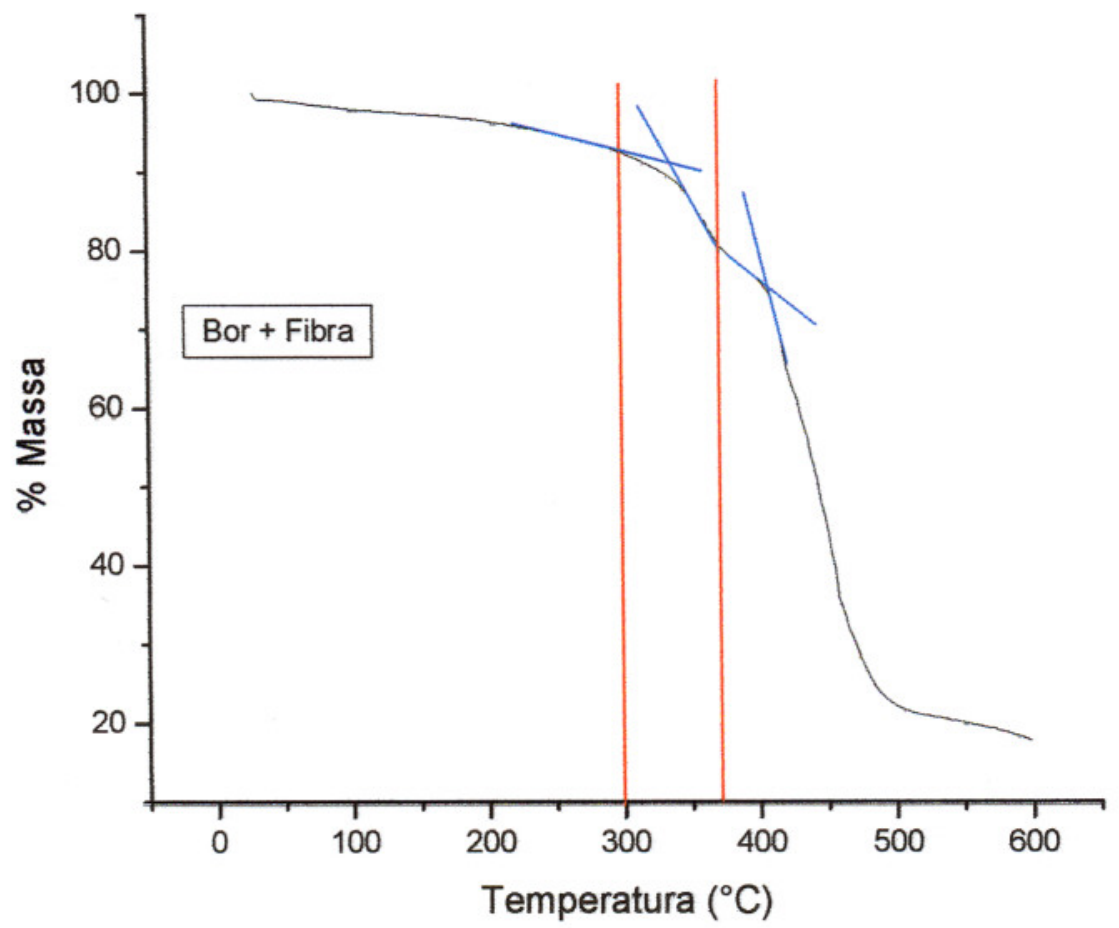

Figura 29: Curva de TG para o compósito de borracha nitrílica com fibras de sisal. Taxa de aquecimento de $10^{\circ} \mathrm{C} / \mathrm{min}$, fluxo de $\mathrm{N}_{2}$ de $15 \mathrm{ml} / \mathrm{min}$.

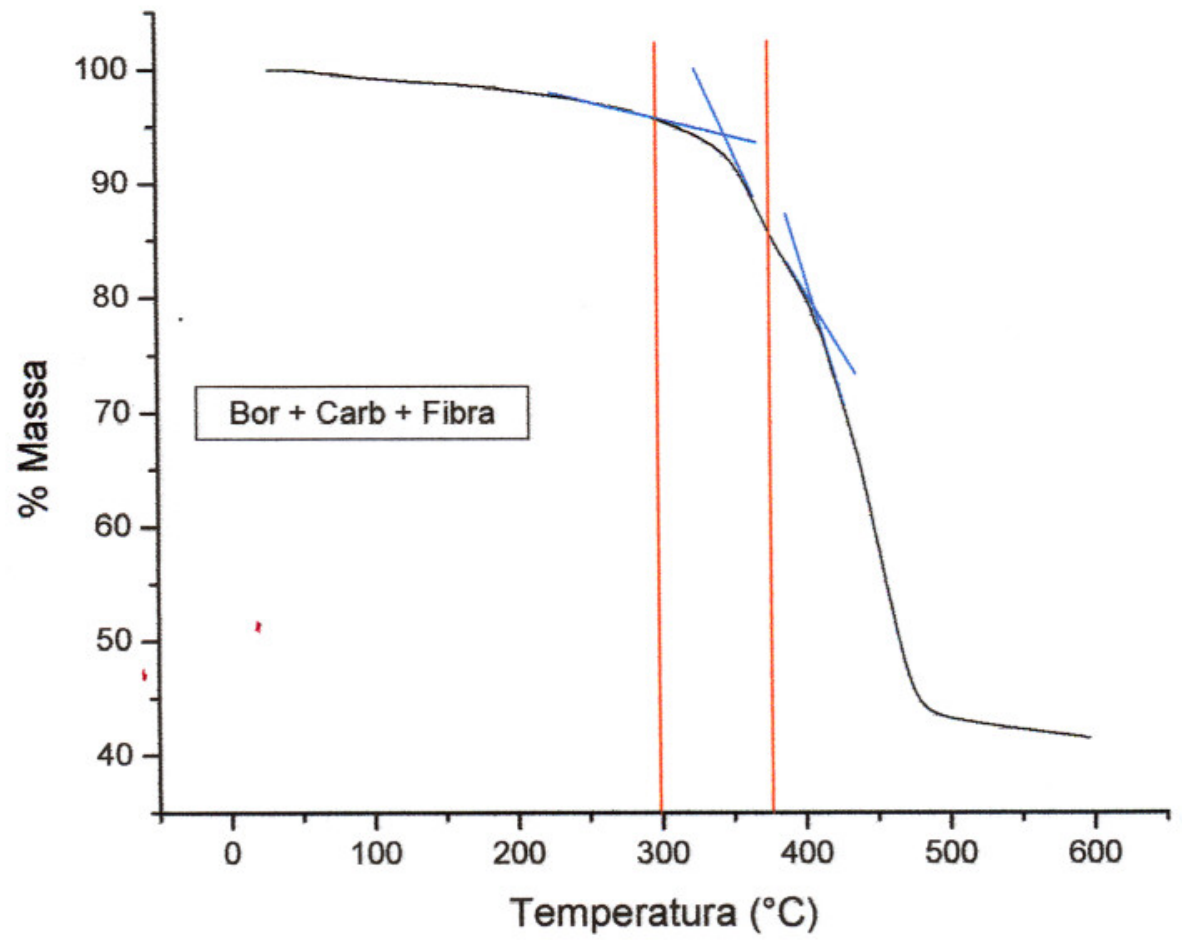

Figura 30: Curva de TG para o compósito de borracha nitrílica com fibras de sisal e carbonato de cálcio. Taxa de aquecimento de $10^{\circ} \mathrm{C} / \mathrm{min}$, fluxo de $\mathrm{N}_{2}$ de $15 \mathrm{ml} / \mathrm{min}$. 
formulação empregada em sua preparação; o que necessariamente não é uma verdade, visto que o tamanho da amostra usada neste tipo de análise é bastante reduzido (10 a $12 \mathrm{mg}$ ). A perda de massa acentua=se a partir de aproximadamente $375^{\circ} \mathrm{C}$, correspondendo à degradação da borracha nitrílica. Nota--se aqui que não pode ser afirmado que a presença das fibras de sisal provocaram um deslocamento na temperatura inicial de degradação da borracha de $340^{\circ} \mathrm{C}$ para $375^{\circ} \mathrm{C}$, visto que nesta temperatura de $375^{\circ} \mathrm{C}$ o teor de perdas de massa é de aproximadamente $20 \%$, não podendo ser, portanto, proveniente unicamente das fibras de sisal no compósito, cujo teor usado na formulação foi de $17,9 \%$, além de que, conforme estimado acima, sua perda de massa é de aproximadamente $35 \%$ no estágío final de análise; o que demonstra que parte da borracha já havia se degradado nesta temperatura de $375^{\circ} \mathrm{C}$. Mais uma vez estes cálculos são feitos considerando-se que a amostra empregada na análise é representativa da formulação original do compósito, o que necessariamente não é uma verdade em função do tamanho de amostra usado neste tipo de análise.

Observa-se ainda através de todos estes gráficos que tanto a presença das fibras de sisal, quanto a do carbonato de cálcio não deslocam a temperatura final de decomposição (próximo a $480^{\circ} \mathrm{C}$ ) da faixa mais expressiva de degradação das amostras.

Encontra-se na literatura [73] menções de casos em que a presença de fibras de sisal em matriz polimérica, leva a uma maior estabilidade térmica do compósito do que as apresentadas pela fibra e matriz separadamente. Referente ao carbonato de cálcio, Claro Neto [74] estudando o efeito desta carga em matriz de poliuretano também encontrou que a mesma não interfere na temperatura de decomposição do polímero.

Ainda, com relação ao apresentado pelo gráfico da Figura 30, confirmou-se 
os resultados estimados anteriormente para os teores de resíduos deixados pelas fibras de sisal e carbonato de cálcio a $600^{\circ} \mathrm{C}$. Pelo cálculo da formulação do compósito o teor de resíduos esperado seria de $42 \%$ e o obtido foi de $41,5 \%$, dando indícios de que as amostras empregadas nas análises apresentavam representatividade bastante razoáveis quanto à formulação original dos compósitos.

Os resultados de degradação térmica das fibras de sisal encontrados neste estudo são concordantes com os descritos na literatura. Paiva e colaboradores [75] relatam que as fibras de sisal apresentam taxas máximas de perdas de massa na faixa de temperatura entre $200^{\circ} \mathrm{C}$ e $400^{\circ} \mathrm{C}$. Martins [15] relata que fibras de sisal mercerizadas apresentam duas etapas de decomposição, sendo o primeiro pico em aproximadamente $360^{\circ} \mathrm{C}$ atribuído à decomposição da celulose e outro em aproximadamente $515^{\circ} \mathrm{C}$ atribuído à degradação dos resíduos. Ferreira [25] determinou que fibras de sisal "in natura" e fibras de sisal deslignificadas apresentam maior perda de massa entre $350-385^{\circ} \mathrm{C}$, comportamento este devido à degradação das estruturas químicas das amostras; e a partir de $450^{\circ} \mathrm{C}$ inicia-se o processo de carbonização das amostras.

As fibras vegetais são compostas de uma variedade de substâncias químicas que apresentam diferentes perfis de degradação. O principal constituinte, celulose, não degrada significativamente abaixo de $400^{\circ} \mathrm{C}$. Já as hemiceluloses e lignina têm uma menor resistência à degradação [76]. A análise térmica é uma importante consideração a ser feita, uma vez que as temperaturas de processamento envolvidas na manufatura de compósitos podem se aproximar daquelas onde as fibras começam a degradar. É geralmente aceito que exposições prolongadas a temperaturas maiores que $200^{\circ} \mathrm{C}$ degradam os polissacarídeos, especialmente as hemiceluloses. Conseqüentemente, as temperaturas de processamento são limitadas à cerca de 
$200^{\circ} \mathrm{C}[76]$.

A partir dos resultados obtidos nestas análises de TG podemos concluir que as temperaturas usadas nos processos de tratamento das fibras de sisal $\left(80^{\circ} \mathrm{C}\right)$ e de obtenção das mantas dos compósitos (máximo de $135^{\circ} \mathrm{C}$ ) não levaram a degradações significativas dos mesmos.

A Figura 31 mostra as curvas das análises de DSC para a borracha nitrílica pura; borracha nitrílica com fibras de sisal mercerizadas; borracha nitrílica com carbonato de cálcio; e borracha nitrílica com fibras de sisal mercerizadas e carbonato de cálcio.

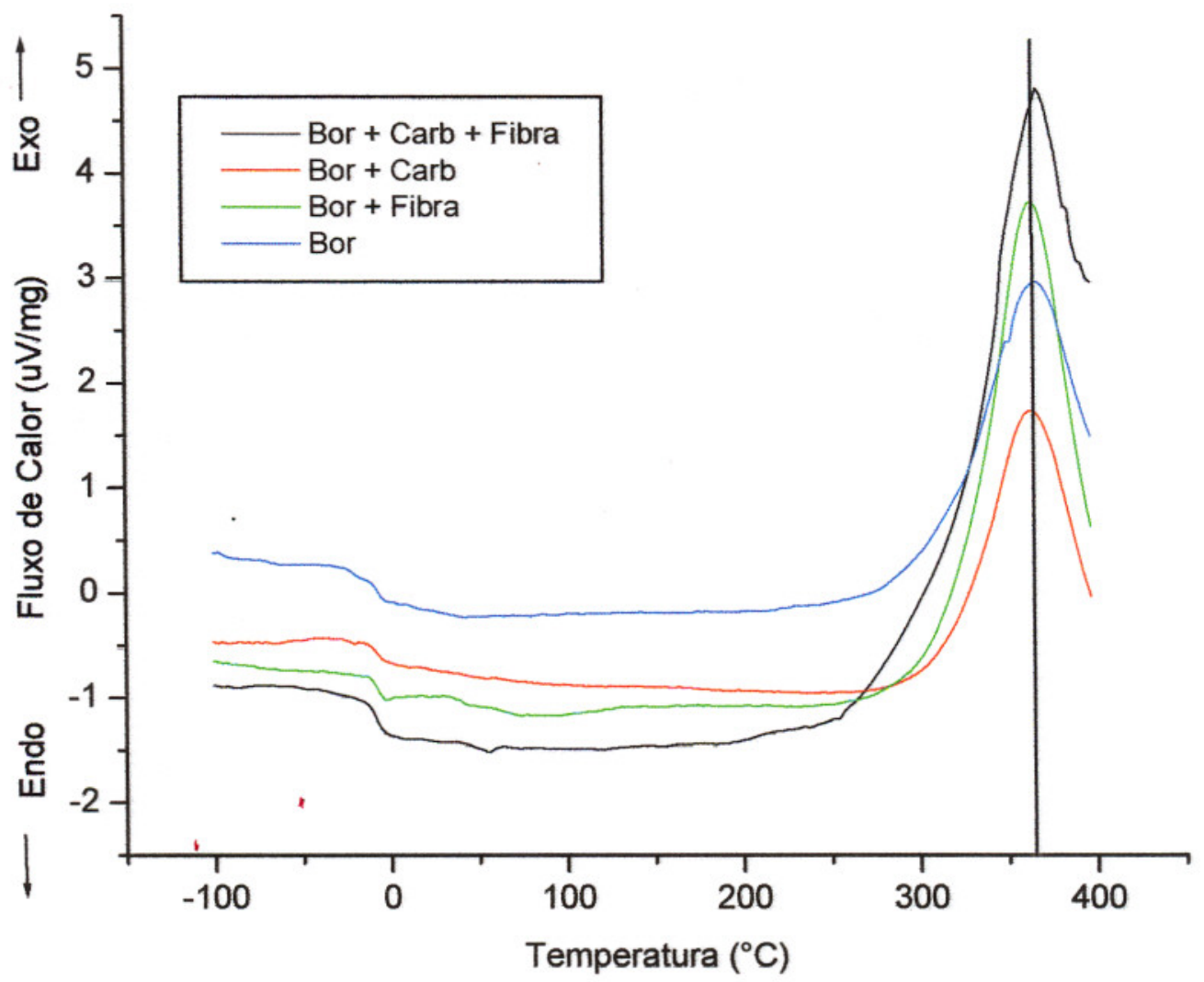

Figura 31: Curvas de DSC para borracha nitrílica, e compósitos de borracha com carbonato, borracha com fibra de sisal, e borracha com fibra de sisal e carbonato. Taxa de aquecimento de $10^{\circ} \mathrm{C} / \mathrm{min}$, fluxo de $\mathrm{N}_{2}$ de $30 \mathrm{ml} / \mathrm{min}$. 
Analisando as curvas da Figura 31, observa-se que todas apresentam basicamente dois picos. Próximo a $-10^{\circ} \mathrm{C}$ evidencia-se uma inflexão, a qual é atribuída à transição vítrea da borracha nitrílica, estando perfeitamente em acordo com o encontrado na literatura [53]. Com o intuito de verificar-se se a presença de fibras de sisal e carbonato de cálcio nos compósitos provoca deslocamentos significativos na temperatura de transição vítrea da borracha, fez-se uma expansão do gráfico próximo a esta região, conforme pode ser visto na Figura 32. A análise das curvas mostra que a presença das cargas não provoca deslocamentos significativos na temperatura de transição vítrea da borracha.

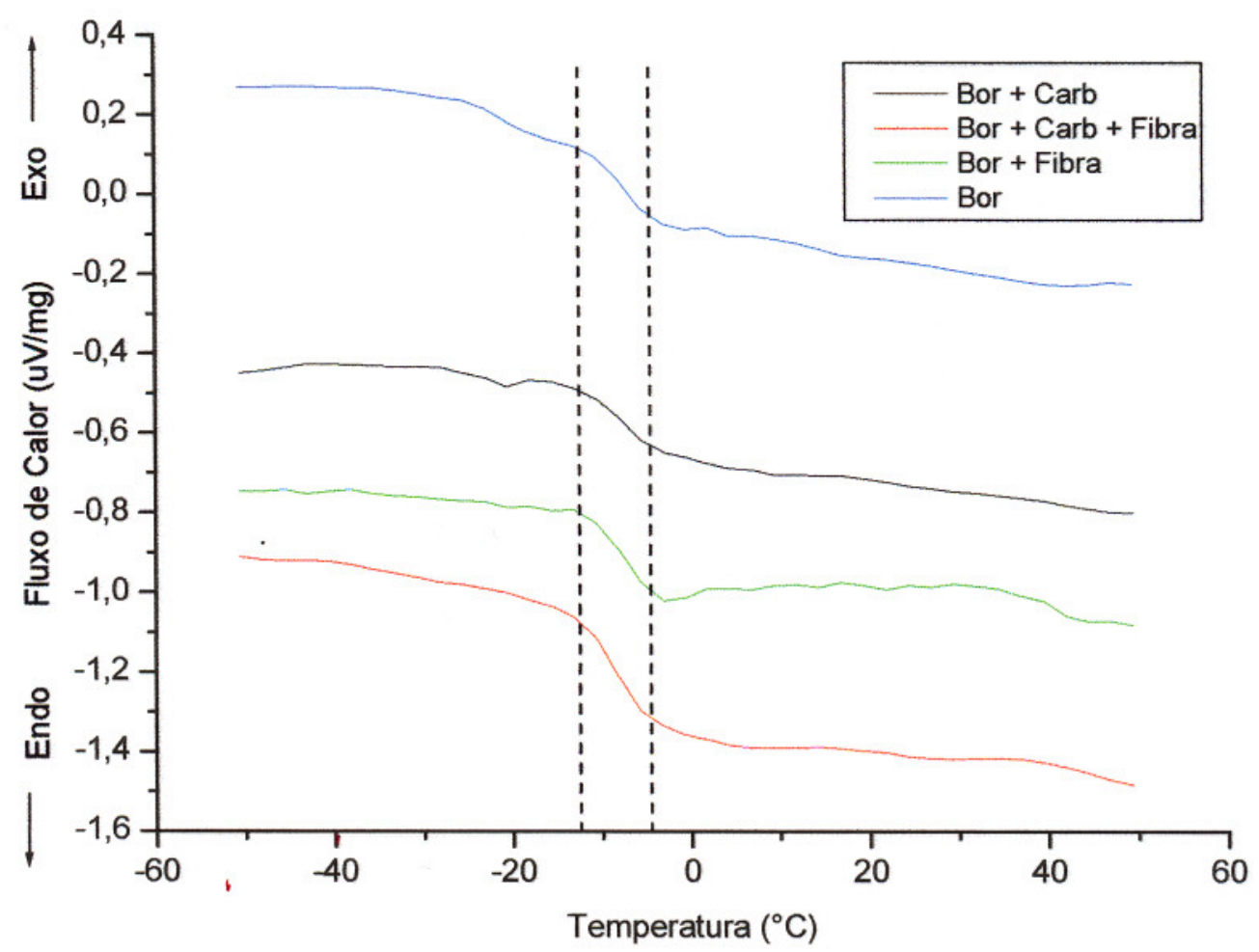

Figura 32: Curvas de DSC para borracha nitrílica, e compósitos de borracha com carbonato, borracha com fibra de sisal, e borracha com fibra de sisal e carbonato. Taxa de aquecimento de $10^{\circ} \mathrm{C} / \mathrm{min}$, fluxo de $\mathrm{N}_{2}$ de $30 \mathrm{ml} / \mathrm{min}$. Ampliação na região da temperatura de transição vítrea da borracha nitrílica. 
Dando seqüência à análise da Figura 31 , próximo a $365^{\circ} \mathrm{C}$ aparece um pico exotérmico intenso, o qual pode ser atribuído à degradação da borracha nitrílica. Observa-se ainda que a presença de fibras de sisal e de carbonato de cálcio não levam a alterações significativas na temperatura de decomposição da borracha, similar aos resultados obtidos nas análises termogravimétricas.

Com relação às amostras compostas por fibras de sisal, o pico de decomposição das mesmas coincide com o da borracha nitrílica. Martins [15] determinou que a degradação da celulose de fibras de sisal mercerizadas ocorrem no pico de temperatura de cerca de $360^{\circ} \mathrm{C}$.

Mais uma vez, este resultado confirma o obtido nas análises de TG, em que foi encontrada uma superposição das curvas de perda de massa da borracha nitrílica com a das fibras de sisal, mostrando que parte da degradação de ambos ocorre na mesma faixa de temperatura. $\mathrm{Na}$ curva de DSC do compósito de borracha com carbonato e fibras de sisal, fica mais perceptível que o processo de decomposição das fibras de sisal inicia em uma temperatura um pouco inferior ao apresentado pela borracha, conforme evidenciado nas análises de TG.

Em resumo, as análises por calorimetria exploratória diferencial permitiram a determinação da temperatura de transição vítrea da borracha nitrílica, e ratificaram as análises de estabilidade térmica previamente obtidas nas curvas termogravimétricas. 


\section{6 - CONCLUSÕES E OBSERVAÇÕES EXPERIMENTAIS IMPORTANTES}

- Os estudos realizados e apresentados nessa dissertação de mestrado para o desenvolvimento de compósitos de borracha nitrílica reforçados com fibras de sisal, mostra-nos que é possível a obtenção desses compósitos pelo processamento por calandragem.

Para a matriz de borracha nitrílica, associada ou não ao carbonato de cálcio, concluiu-se que nas condições experimentais empregadas o sisal se constitui numa carga de reforço eficiente. $O$ tamanho crítico de fibras para otimização das propriedades mecânicas é de $6 \mathrm{~mm}$.

O tratamento de mercerização das fibras contribui para elevar as propriedades mecânicas dos compósitos estudados. Com um nivel de eficiência um pouco menor, a lavagem das fibras com água a $80^{\circ} \mathrm{C}$ por $1 \mathrm{~h}$, também se manifesta favorável para a melhoria destas propriedades.

A presença da carga mineral carbonato de cálcio, não prejudica no processo de interação fibra/matriz de borracha nitrílica. Mais do que isso, quando em conjunto 
com fibras de sisal ele funciona como verdadeira carga de reforço, e não apenas como uma carga de enchimento, que barateia o custo do compósito como freqüentemente é empregado. Dentro da faixa de estudos realizados, o teor de $67 \mathrm{pcr}$ é o que apresenta maiores contribuições para reforço da matriz.

As fibras de sisal passam a exercer uma ação de reforço na matriz de borracha nitrílica pura a partir de 11 pcr. Para a matriz de borracha associada ao carbonato de cálcio este reforço já se inicia com teores de fibra na ordem de 5,5 pcr.

Os compósitos de borracha nitrílica com fibras de sisal e carbonato de cálcio são termicamente estáveis até cerca de $300^{\circ} \mathrm{C}$ nas condições estudadas.

Devido aos baixos custos das fibras de sisal e de carbonato de cálcio frente ao custo da borracha nitrílica, o uso associado destas fibras com o carbonato constitui num fator economicamente muito interessante para sua utilização. O uso combinado, de por exemplo, 67 per de carbonato com 35 pcr de fibras de sisal mercerizadas produz um compósito com valor de tensão de ruptura equivalente ao obtido para a borracha nitrilica pura; e com valor de módulo a $10 \%$ superior a $500 \%$ ao obtido para a borracha pura. Ou seja, é possível obter-se compósitos com boas propriedades mecânicas com custos bastante reduzidos. 


\section{7- ANEXOS}

Anexo A: Resultados médios de propriedades mecânicas. Estudo da variação do teor de carbonato de cálcio sobre borracha.

\begin{tabular}{|c|c|c|c|}
\hline $\begin{array}{c}\text { Teor de Carbonato } \\
\text { (por) }\end{array}$ & $\begin{array}{c}\text { Elongagio } \\
(\%)\end{array}$ & $\begin{array}{c}\text { Tensüo do Ruptura } \\
\text { (MPa) }\end{array}$ & $\begin{array}{c}\text { Modulo 10\% } \\
\text { (MPa) }\end{array}$ \\
\hline 0 & $692 \pm 71$ & $2,04 \pm 0,12$ & $2,27 \pm 0,24$ \\
\hline 11 & $765 \pm 57$ & $2,25 \pm 0,14$ & $2,39 \pm 0,20$ \\
\hline 33 & $911 \pm 76$ & $2,41 \pm 0,16$ & $2,45 \pm 0,19$ \\
\hline 60 & $946 \pm 58$ & $2,20 \pm 0,16$ & $2,67 \pm 0,13$ \\
\hline 67 & $1195 \pm 86$ & $2,03 \pm 0,08$ & $2,71 \pm 0,16$ \\
\hline 90 & $994 \pm 73$ & $1,91 \pm 0,17$ & $2,90 \pm 0,21$ \\
\hline 133 & $943 \pm 53$ & $1,91 \pm 0,10$ & $3,27 \pm 0,22$ \\
\hline 200 & $930 \pm 57$ & $1,83 \pm 0,13$ & $3,95 \pm 0,25$ \\
\hline
\end{tabular}

Anexo B: Resultados médios de propriedades mecânicas. Estudo da variação do tamanho de fibra de sisal lavado sobre borracha pura, borracha com 33 pcr de carbonato e borracha com 67 pcr de carbonato. Teor de fibra mantido constante em 22 pcr.

\begin{tabular}{|c|c|c|c|c|c|c|c|c|c|}
\hline \multirow{2}{*}{$\begin{array}{c}\text { Tamanho } \\
\text { de Fibra } \\
\text { (mm) }\end{array}$} & \multicolumn{3}{|c|}{ \% Elongag̣ăo } & \multicolumn{3}{|c|}{ Tensão de Ruptura (MPa) } & \multicolumn{3}{|c|}{ Módulo 10\% (MPa) } \\
\hline & $\begin{array}{c}\text { Borracha } \\
\text { pura }\end{array}$ & $\begin{array}{c}\text { Bor }+33 \\
\text { Carb }\end{array}$ & $\begin{array}{c}\text { Bor }+67 \\
\text { Carb }\end{array}$ & $\begin{array}{c}\text { Borracha } \\
\text { pura }\end{array}$ & $\begin{array}{c}\text { Bor }+33 \\
\text { Carb }\end{array}$ & $\begin{array}{c}\text { Bor }+67 \\
\text { Carb }\end{array}$ & $\begin{array}{c}\text { Borracha } \\
\text { pura }\end{array}$ & $\begin{array}{c}\text { Bor }+33 \\
\text { Carb }\end{array}$ & $\begin{array}{c}\text { Bor }+67 \\
\text { Carb }\end{array}$ \\
\hline 0 & $\underset{71}{761} \pm$ & $\underset{88}{993} \pm$ & $\begin{array}{r}1172 \\
96\end{array} \pm$ & $\underset{0,12}{1,99} \pm$ & $\underset{0,11}{2,29} \pm$ & $\begin{array}{c}1,77 \pm \\
0,08\end{array}$ & $\underset{0,24}{2,15} \pm$ & $\begin{array}{c}2,41 \pm \\
0,26\end{array}$ & $\underset{0,21}{2,74} \pm$ \\
\hline 3 & $\begin{array}{c}476 \pm \\
37\end{array}$ & $\underset{36}{594} \pm$ & $\underset{27}{410 \pm}$ & $\underset{0,06}{1,09 \pm}$ & $\underset{0,06}{1,22} \pm$ & $\underset{0,06}{1,09} \pm$ & $\underset{0,25}{2,31} \pm$ & $\begin{array}{c}4,89 \pm \\
0,34\end{array}$ & $\begin{array}{c}4,57 \pm \\
0,54\end{array}$ \\
\hline 6 & $\begin{array}{c}478 \\
57\end{array}$ & $\underset{41}{348 \pm}$ & $\begin{array}{c}258 \pm \\
50\end{array}$ & $\begin{array}{c}1,42 \\
0,15\end{array} \pm$ & $\begin{array}{c}1,16 \pm \\
0,12\end{array}$ & $\begin{array}{c}1,40 \pm \\
0,14\end{array}$ & $\begin{array}{c}3,27 \pm \\
0,38\end{array}$ & $\begin{array}{c}6,86 \pm \\
0,32\end{array}$ & $\begin{array}{c}7,91 \\
0,67\end{array}{ }^{ \pm}$ \\
\hline 10 & $\begin{array}{c}394 \\
59\end{array}$ & $\underset{34}{356 \pm}$ & $\underset{57}{321} \pm$ & $\underset{0,09}{1,20 \pm}$ & $\begin{array}{c}0,90 \pm \\
0,08\end{array}$ & $\begin{array}{c}1,18 \\
0,08\end{array}$ & $\begin{array}{c}3,16 \pm \\
0,48\end{array}$ & $\underset{0,34}{6,24} \pm$ & $\begin{array}{c}6,40 \pm \\
0,52\end{array}$ \\
\hline 14 & ${ }_{34}^{364} \pm$ & $\underset{33}{270 \pm}$ & $\frac{317}{41} \pm$ & $\underset{0,12}{1,19} \pm$ & $\underset{0,11}{0,92} \pm$ & $\underset{0,11}{1,05} \pm$ & $\underset{0,29}{2,95} \pm$ & $\underset{0,32}{5,82} \pm$ & $\underset{0,48}{5,30} \pm$ \\
\hline
\end{tabular}


Anexo C: Resultados médios de propriedades mecânicas. Estudo do efeito do tratamento empregado na fibra de sisal sobre borracha pura, borracha com 33 pcr de carbonato e borracha com 67 pcr de carbonato. Teor de fibra mantido constante em $22 \mathrm{pcr}$, e tamanho de $6 \mathrm{~mm}$.

\begin{tabular}{|c|c|c|c|c|c|c|c|c|c|}
\hline \multirow{2}{*}{$\begin{array}{l}\text { Tipo de } \\
\text { Tratamento }\end{array}$} & \multicolumn{3}{|c|}{ \% Elongaçăo } & \multicolumn{3}{|c|}{ Tensão de Ruptura (MPa) } & \multicolumn{3}{|c|}{ Módulo 10\% (MPa) } \\
\hline & $\begin{array}{l}\text { Borracha } \\
\text { Pura }\end{array}$ & $\begin{array}{c}33 \\
\text { Carbon. }\end{array}$ & $\begin{array}{c}67 \\
\text { Carbon. }\end{array}$ & $\begin{array}{c}\text { Borracha } \\
\text { Pura }\end{array}$ & $\begin{array}{c}33 \\
\text { Carbon. }\end{array}$ & $\begin{array}{c}67 \\
\text { Carbon. }\end{array}$ & $\begin{array}{c}\text { Borracha } \\
\text { Pura }\end{array}$ & $\begin{array}{c}33 \\
\text { Carbon. }\end{array}$ & $\begin{array}{c}67 \\
\text { Carbon. }\end{array}$ \\
\hline Sem fibra & $\begin{array}{c}805 \pm \\
102\end{array}$ & $\begin{array}{c}974 \pm \\
81\end{array}$ & $\begin{array}{c}1180 \pm \\
93\end{array}$ & $\begin{array}{c}1,90 \pm \\
0,13\end{array}$ & $\begin{array}{c}2,37 \pm \\
0,14\end{array}$ & $\begin{array}{c}1,86 \pm \\
0,11\end{array}$ & $\begin{array}{c}2,27 \pm \\
0,26\end{array}$ & $\begin{array}{c}2,44 \pm \\
0,23\end{array}$ & $\begin{array}{c}2,71 \pm \\
0,26\end{array}$ \\
\hline $\begin{array}{l}\text { Fibra sem } \\
\text { Tratamento }\end{array}$ & $\begin{array}{c}384 \pm \\
38\end{array}$ & $\begin{array}{c}351 \pm \\
62\end{array}$ & $\begin{array}{c}270 \pm \\
43\end{array}$ & $\begin{array}{c}0,79 \pm \\
0,07\end{array}$ & $\begin{array}{c}1,08 \pm \\
0,12\end{array}$ & $\begin{array}{c}1,18 \pm \\
0,13\end{array}$ & $\begin{array}{c}3,08 \pm \\
0,31\end{array}$ & $\begin{array}{c}6,47 \pm \\
0,77\end{array}$ & $\begin{array}{c}7,01 \pm \\
0,52\end{array}$ \\
\hline Lavada & $\begin{array}{c}397 \pm \\
52\end{array}$ & $\begin{array}{c}348 \pm \\
41\end{array}$ & $\begin{array}{c}247 \pm \\
32\end{array}$ & $\begin{array}{c}0,84 \pm \\
0,11\end{array}$ & $\begin{array}{c}1,16 \pm \\
0,12\end{array}$ & $\begin{array}{c}1,40 \pm \\
0,14\end{array}$ & $\begin{array}{c}3,27 \pm \\
0,49\end{array}$ & $\begin{array}{c}6,86 \pm \\
0,61\end{array}$ & $\begin{array}{c}7,91 \pm \\
0,58\end{array}$ \\
\hline Mercerizada & $\begin{array}{c}340 \pm \\
46\end{array}$ & $\begin{array}{c}371 \pm \\
36\end{array}$ & $\begin{array}{c}258 \pm \\
43\end{array}$ & $\begin{array}{c}0,98 \pm \\
0,10\end{array}$ & $\begin{array}{c}1,32 \pm \\
0,11\end{array}$ & $\begin{array}{c}1,40 \pm \\
0,10\end{array}$ & $\begin{array}{c}3,36 \pm \\
0,37\end{array}$ & $\begin{array}{c}7,28 \pm \\
0,73\end{array}$ & $\begin{array}{c}9,03 \pm \\
0,64\end{array}$ \\
\hline
\end{tabular}

Anexo D: Resultados médios de propriedades mecânicas. Estudo da variação do teor de fibra de sisal mercerizado sobre borracha pura e borracha com 67 pcr de carbonato. Tamanho de fibra mantido constante em $6 \mathrm{~mm}$.

\begin{tabular}{|c|c|c|c|c|c|c|}
\hline \multirow{2}{*}{$\begin{array}{c}\text { Teor de } \\
\text { Flbra }\end{array}$} & \multicolumn{2}{|c|}{$\%$} & \multicolumn{2}{c|}{$\begin{array}{c}\text { Tensão de Ruptura } \\
\text { (MPa) }\end{array}$} & \multicolumn{2}{c|}{ Módulo 10\% (MPa) } \\
\cline { 2 - 7 } & $\begin{array}{c}\text { Borracha } \\
\text { Pura }\end{array}$ & 67 Carbon. & $\begin{array}{c}\text { Borracha } \\
\text { Pura }\end{array}$ & 67 Carbon. & $\begin{array}{c}\text { Borracha } \\
\text { Pura }\end{array}$ & 67 Carbon. \\
\hline 0 & $870 \pm 92$ & $1202 \pm 82$ & $1,62 \pm 0,14$ & $1,71 \pm 0,08$ & $2,29 \pm 0,26$ & $2,68 \pm 0,19$ \\
\hline 5,5 & $814 \pm 49$ & $886 \pm 68$ & $1,27 \pm 0,10$ & $1,35 \pm 0,11$ & $2,35 \pm 0,18$ & $3,01 \pm 0,26$ \\
\hline 11 & $639 \pm 69$ & $583 \pm 78$ & $1,17 \pm 0,12$ & $1,22 \pm 0,06$ & $2,47 \pm 0,24$ & $4,39 \pm 0,55$ \\
\hline 22 & $399 \pm 76$ & $290 \pm 39$ & $0,98 \pm 0,09$ & $1,22 \pm 0,09$ & $3,36 \pm 0,46$ & $9,11 \pm 0,87$ \\
\hline 33 & $303 \pm 46$ & $136 \pm 35$ & $0,90 \pm 0,11$ & $1,57 \pm 0,12$ & $3,46 \pm 0,78$ & $13,43 \pm 1,10$ \\
\hline 44 & $171 \pm 44$ & $68 \pm 21$ & $0,89 \pm 0,07$ & $1,77 \pm 0,12$ & $6,66 \pm 1,41$ & $15,14 \pm 0,57$ \\
\hline
\end{tabular}




\section{7 - REFERÊNCIAS BIBLIOGRÁFICAS}

1. SMITH, W.F. Princípios de Ciência e Engenharia de Materiais, McGraw-Hill. Alfragide - Portugal. p. 8-9, 767-768, 1998.

2. ASKELAND, D.R. The Science and Engineering of Materials, PWS Publishing Company, Boston - USA, p.527-572, 1994.

3. JOSEPH, K.R; MATTOSO, L.H.C.; TOLEDO, R.D.; THOMAS, S.; CARVALHO, L.H.; POTHEN, L.; KALA, S.; JAMES, B. Natural Fiber Reinforced Thermoplastic Composites, Natural Polymers and Agrofibers Based Composites, edited by Frollini, E.; Leão, A.; Mattoso, L.H.C., São Carlos: IQSC/USP, UNESP and Embrapa Instrumentação Agropecuária, p. 159-201, 2000.

4. MARTIN, A.R. Caracterização e Modificação de Sisal por Plasma a Frio Visando Aplicação em Compósitos Poliméricos. Tese de Doutorado, São Carlos - UFSCAR, 2001.

5. JOSEPH, K.; MATTOSO, L.H.C. Sisal Fibre Reinforced Polymer Composites: Status and Future. Natural Polymers and Composites, p. 333-343, 2000.

6. NOTHENBERG, M. Cresce o Interesse pelo Uso de Fibras Naturais. Plástico Moderno, v. 263, p. 6-15, 1996.

7. BLEDZKI, A.K.; REIHMANE, S., GASSAN, J. Properties and Modification Methods for Vegetable Fibers for Natural Fiber Composites. Journal of Applied 
Polymer Science, v. 59, p. 1329-1336, 1996.

8. SERA, E.E., ROBLES-AUSTRIACO, L.; PAMA, R.P. Natural Fibers as Reinforcement. Journal of Ferrocement, v. 20, p. 109-124, 1990.

9. SATYANARAYANA, K.G.; SUKUMARAN, K.; MUKHERJEE, P.S.; PAVITHRAN, C.; PILLAI, S.G.K. Natural fibre-Polymer Composites. Cement \& Concrete Composite, v. 12, p. 117-136, 1990.

10. FELIX, J.M.; GATENHOLM, P. The Nature of Adhesion in Composites of Modified Cellulose Fibers and Polypropylene. Journal of Applied Polymer Science, v. 42, p. 609-620, 1991.

11. MARTINS, M.A.; FORATO, L.A.; COLNAGO, L.A.; MATTOSO, L.H.C. Characterization of Mercerized and Acetylated Sisal Fibers by Solid State NMR, Natural Polymers and Composites IV, edited by Mattoso, L.H.C.; Leão, A.; Frollini, E., São Carlos: Embrapa Instrumentação Agropecuária, UNESP and IQSC/USP, p. 85-90, 2002.

12. OASHI, M.C.G. Estudo da Cadeia Produtiva como Subsídio para Pesquisa e Desenvolvimento do Agronegócio do Sisal na Paraíba. Tese de Doutorado, Engenharia de Produção - UFSC, 1999.

13. PAULA, C.M.S.S. Estudo da Influência do Tratamento Químico de Fibras de Sisal na Resistência Mecânica de Compósitos Sisal/Epóxi. Dissertação de Mestrado, Faculdade de Engenharia Química - UNICAMP, 1996.

14. TSUNECHIRO, A. Receita Agricola Brasileira: Houve Queda na Safra 1994/95? Informações Econômicas, v. 25, p. 88-92, 1995.

15. MARTINS, M.A. Fibra de Sisal: Mercerização, Acetilação e Aplicação em Compósitos de Borracha de Pneu Triturado. Tese de Doutorado, Instituto de Química - UNICAMP, 2001.

$$
\begin{aligned}
& \text { IFSC-USP SERVIÇO DE BIBLIOTECA } \\
& \text { INFORMACÁO }
\end{aligned}
$$


16. BISANDA, E.T.N.; ANSELL, M.P. Properties of Sisal-CNSL Composites. Journal of Materials Science, v. 27, p. 1690-1700, 1992.

17. LI, Y.; MAI, Y.; YE, L. Sisal fibre and its composites: a review of recent developments. Composites Science and Technology, v. 60, p. 2037-2055, 2000.

18. LOPEZ, O. H., Utilização de Fibras Vegetais no Fibro-Cimento e no ConcretoFibra. CEPED, Camaçari/BA, 1982.

19. MWAIKAMBO, L.Y.; ANSELL M.P., The Effect of Chemical Treatment on the Properties of Hemp, Sisal, Jute and Kapok for Composite Reinforcement. Die Angewandte Makromolekulare Chemie, v. 272, p. 108-116, 1999.

20. MATTOSO, L.H.C.; FERREIRA, F.C.; CURVELO, A.A.S. Sisal Fiber: Morphology and Applications in Polymer Composites. p. 241-299, em Leão, A.L.; Carvalho, F.X.; Frollini, E. (edts), Lignocellulosic-Plastic Composites. São Paulo, 1997.

21. BLEDZKI, A.K.; GASSAN, J. Composites reinforced with cellulose based fibres. Progress in Polymer Science, v. 24, p. 221-274, 1999.

22. JOSEPH, P.V.; MATHEW, G.; JOSEPH, K.; GROENINCKX, G.; THOMAS, S. Dynamic Mechanical Properties of Short Sisal Fibre Reinforced Polypropylene Composites. Composites - Part A: Applied Science and Manufacturing, p. 1$16,2002$.

23. VARGHESE, S.; KURIAKOSE, B.; THOMAS, S.; KOSHY, A.T. Mechanical and Viscoelastic Properties of Short Fiber Reinforced Natural Rubber Composites: Effects of Interfacial Adhesion, Fiber Loading, and Orientation. Journal of Adhesives and Technology, v. 8, p. 235-248, 1994.

24. SILVA, O.R.R.F.; BELTRÃO, N.E.M.; MATTOSO, L.H.C.; FREIRE, R.M.M. Determinação das características físico-químicas da fibra do sisal. 0 
agronegócio do sisal no Brasil. Brasília: EMBRAPA-SPI, p. 111-123, 1999.

25. FERREIRA, F.C. Deslignificação e Benzilação de Fibras de Sisal. Dissertação de Mestrado, Instituto de Química - USP São Carlos, 1997.

26. SJOSTRON, E. Wood Chemistry - Fundamentals and applications. New York Academic Press, p.221, 1981.

27. FENGEL, D.; WEGENER, G. Wood Chemistry, Ultrastructure and Reactions. Berlin, Walter de Gruyter, p. 66-220, 320, 613, 1984.

28. DENCE, C.W.;LIN, S.J. Methods in lignin chemistry. Berlin, Springer Verlag, cap.1, 1992.

29. SILVA, J.L.G.; AL-QURESHI, H.A. Mechanics of Wetting Systems of Natural Fibres with Polymeric Resin. Journal of Materials Processing Technology, v. 92-93, p. 124-128, 1999.

30. GOSH, P.; GANGOPADHYAY, R. Photofunctionalization of Cellulose and Lignocellulose Fibres Using Photoactive Organic Acids. European Polymer Journal, v. 36, p. 625-634, 2000.

31. SAVASTANO JR., H.; WARDEN, P.G.; COUTTS, R.S.P. Brazilian Waste Fibres as Reinforcement for Cement-based Composites. Cement \& Concrete Composites, v. 22, p. 379-384, 2000.

32. JOSEPH, K.; VARGHESE, S.; KALAPRASAD, G.; THOMAS, S.; PRASANNAKUMARI, L.; KOSHY, P.; PAVITHRAN, C. Influence of Interfacial Adhesion on the Mechanical Properties and Fracture Behaviour of Short Sisal Fibre Reinforced Polymer Composites. European Polymer Journal, v. $32, \mathrm{~N}^{\circ} 10$, p. $1243-1250,1996$.

33. SINGH, B.; GUPTA, M.; VERMA, A.; TYAGI, O.S. FT-IR Microscopic Studies on Coupling Agents: Treated Natural Fibres. Polymer International, v. 49, p. 
1444-1451, 2000.

34. SINGH, B.; VERMA, A.; GUPTA, M. Studies on Adsorptive Interaction Between Natural Fiber and Coupling Agents. Journal of Applied Polymer Science, v. 70, p. 1847-1858, 1998.

35. COSTA, F.H.M.M.; D'ALMEIDA, J.R.M. Effect of Water Absorption on the Mechanical Properties of Sisal and Jute Fiber Composites. Polymer-Plastics Technology and Engineering, v. 38, p. 1081-1094, 1999.

36. IANNACE, S.; ALI, R; NICOLAIS, L. Effect of Processing Conditions on Dimensions of Sisal Fibers in Thermoplastic Biodegradable Composites. Journal of Applied Polymer Science, v. 79, p. 1084-1091, 2001.

37. JOSEPH, K.; TOLEDO FILHO, R.D.; JAMES, B.; THOMAS, S.; CARVALHO, L.H. A Review on Sisal Fibre Reinforced Polymer Composites. Revista Brasileira de Engenharia Agrícola e Ambiental, v.3, No 3, p. 367-379, 1999.

38. MUKHERJEE, P.S.; SATYANARAYANA, K.G. Structure and Properties of Some Vegetable Fibres - Part 1 : Sisal Fibre. Journal of Materials Science, v. 19 , p. $3925-3934,1984$.

39. JOSEPH, K.; THOMAS, S. Dynamic Mechanical Properties of Short Sisal Fiber Reinforced Low Density Polyethylene Composites. Journal of Reinforced Plastics and Composites, v. 12, p. 139-155, 1993.

40. JOSEPH, K.; KURIAKOSE, B.; PREMALATHA, C.K.; THOMAS, S. Melt Rheological behaviour of Short Sisal Fibre Reinforced Polyethylene Composites. Plastics, Rubber and Composites Processing Applications, v. 21, p. 237-245, 1994.

41. JOSEPH, K.; THOMAS, S.; PAVITHRAN, C. Effect of Chemical treatment on the Tensile Properties of Short Sisal Fibre-reinforced Polyethylene Composites. 
Polymer, v. 37, No 23, p. 5139-5149, 1996.

42. ALBANO, C.; GONZÁLEZ, J.; ICHAZO, M.; KAISER, D. Thermal Stability of Blends of Polyolefins and Sisal Fiber. Polymer degradation and Stability, v. 66, p. 179-190, 1999.

43. JOSEPH, P.V.; JOSEPH, K.; THOMAS, S. Effect of Processing Variables on the Mechanical Properties of Sisal Fiber Reinforced Polyprophylene Composites. Composites Science and Technology, v. 59, p. 1625-1640, 1999.

44. NAIR, K.C.M.; THOMAS, S.; GROENINCKX, G. Thermal and Dynamic Mechanical Analysis of Polystyrene Composites Reinforced with Short Fibres. Composites Science and Technology, v. 61, p. 2519-2529, 2001.

45. SATYANARAYANA， K.G.; SUKUMARAN， K.; MUKHERJEE， P.S.; PAVITHRAN, C.; PILLAI, S.G.K. Natural Fibre-Polymer Composites. Cement and Concrete Composite, v. 12, p. 117-136, 1990.

46. OKSMAN, K.; WALLSTRÖM, L.; BERGLUND, L.; TOLEDO, R.D. Mechanical Properties and Morphology of Sisal Fibre-Epoxy Composites. Natural Polymers and Composites, p. 355-361, 2000.

47. ALMEIDA, J.R.M., Fibre-Matrix Interface and Natural Fibre Composites. Journal of Materials Science Letters, v. 2, p. 578-580, 1991.

48. JOSEPH, K.; THOMAS, S.; PAVITHRAN, C. Viscoelastic Properties of Short Sisal Fiber Filled Low density Polyethylene Composites: Effect of Fiber Length and Orientation. Materials Letters, v. 15, p. 224-228, 1992.

49. JOSEPH, K.; THOMAS, S.; PAVITHRAN, C.; BRAHMAKUMAR, M. Tensile Properties of Short Sisal Fiber-Reinforced Polyethylene Composites. Journal of Applied Polymer Science, v. 47, p. 1731-1739, 1993.

50. MILES, D.C.; BRISTON, J.H., Tecnologia dos Polímeros. São Paulo, p. 359 - 
$400,523-526,1975$.

51. WINSPEAR, G.G., The Vanderbilt Rubber Handbook, Norwalk, p. 99-118, 1968.

52. JERRAMS, S.J.; KAYA, M.; SOON, K.F. The Effects of Strain Rate and Hardness on the Material Constants of Nitrile Rubbers. Materials \& Design, v. 19, p. 157-167, 1998.

53. VARGHESE, H.; BHAGAWAN, S.S.; RAO, S.S.; THOMAS, S. Morphology, Mechanical and Viscoelastic Behaviour of Blends of Nitrile Rubber and Ethylene-Vinyl Acetate Copolymer. European Polymer Journal, v. 31, p. 957$967,1995$.

54. NUNES, R.C.R.; VISCONTE, L.L.Y. Natural Fibers / Elastomeric Composites, Natural Polymers and Agrofibers Based Composites, edited by Frollini, E.; Leão, A.; Mattoso, L.H.C., São Carlos: IQSC/USP, UNESP and Embrapa Instrumentação Agropecuária, p. 135-157, 2000.

55. BOTROS, S.H.; ABDEL-NOUR, K.N. Preparation and Characterization of Butyl/NBR Vulcanizates. Polymer Degradation and Stability, v. 62, p. 479$485,1998$.

56. GEORGE, J.; VARUGHESE, K.T.; THOMAS, S. Dinamically Vulcanized Thermoplastic Elastomer Blends of Polyethylene and Nitrile Rubber. Polymer, v. 41, p. $1507-1517,2000$.

57. ZHANG, X.; HUANG, H.; ZHANG, Y. Dynamically Vulcanized Nitrile Rubber/Polypropylene Thermoplastic Elastomers. Journal of Applied Polymer Science, v. 85, p. 2862-2866, 2002.

58. VARGHESE, S.; KURIAKOSE, B.; THOMAS, S.; KOSHY, A.T. Studies on Natural Rubber-Short Sisal Fibre Composites. Indian Journal of Natural 
Rubber Research, v. 4(1), p. 55-67, 1991.

59. VARGHESE, S.; KURIAKOSE, B.; THOMAS, S.; KOSHY, A.T. Dynamic Mechnical Properties of Short Sisal Fibre Reinforced Natural Rubber Composites. Indian Journal of Natural Rubber Research, v. 5 (1\&2), p. 18$24,1992$.

60. VARGHESE, S.; KURIAKOSE, B.; THOMAS, S. Stress relaxation in Short Sisal-Fiber-Reinforced Natural Rubber Composites. Journal of Applied Polymer Science, v. 53, p. 1051-1060, 1994.

61. GEETHAMMA, V.G.; JOSEPH, R.; THOMAS, S. Short Coir Fiber-Reinforced Natural Rubber Composites: Effects of Fiber Length, Orientation, and Alkali Treatment. Journal of Applied polymer Science, v. 55, p. 583-594, 1995.

62. KUMAR, R.P.; THOMAS, S. Tear and Processing Behaviour of Short Sisal Fibre Reinforced Styrene Butadiene Rubber Composites. Polymer International, v. 38, p. 173-182, 1995.

63. VARGHESE, S.; KURIAKOSE, B. \& THOMAS, S. Short Sisal Fibre Reinforced Natural Rubber Composites: High-Energy Radiation, Thermal and Ozone Degradation. Polymer Degradation and Stability, v. 44, p.55-61, 1994.

64. JOSEPH, K.; MATTOSO, L. H. C. Sisal Fibre Reinforced Polymer Composites: Status and Future. Anais do Third International Symposium on Natural Polymer and Composites, p. 333-343, São Paulo, 2000.

65. ISMAIL, H.; ROSNAH, N.; ROZMAN, H. D. Curing Characteristics and Mechanical Properties of Short Oil Palm Fibre Reinforced Rubber Composites. Polymer, v. 38, No 16, p. 4059-4064, 1997.

66. ISMAIL, H.; ROSNAH, N.; ROZMAN, H. D. Effects of Various Bonding Systems on Mechanical Properties of Oil Palm Fibre Reinforced Rubber 
Composites. European Polymer Journal, v. 33 (8), p. 1231-1238, 1997.

67. GEETHAMMA， V.G.; MATHEW， K.T.; LAKSHMINARAYANAN R.; THOMAS, S. Composite of Short Coir Fibres and Natural Rubber: Effect of Chemical Modification, Loading and Orientation of Fibre. Polymer, v. 39, p. 1483-1491, 1998.

68. PATTON, T.C. Pigment Handbook - Properties and Economics. John Wiley \& Sons, v. 1, p. 109-128, New Jersey, 1972.

69. KRYSZTAFKIEWICZ, A. Use of Highly Dispersed, Precipitated Carbonatesilicate Powders as Fillers for Elastomers. Powder Technology, v.63, p. 1$11,1990$.

70. POH, B.T.; ISMAIL, H.; TAN, K.S. Effect of Filler Loading on Tensile and Tear Properties of SMR L/ENR 25 and SMR L/SBR Blends Cured Via a Semiefficient Vulcanization System. Połymer Testing, v. 21, p. 801-806, 2002.

71. SAAD, A.L.G.; YOUNAN, A.F. Rheological, Mechanical and Electrical Properties of Natural Rubber-White Filler Mixtures Reinforced with Nylon 6 Short Fibers. Polymer Degradation and Stability, v. 50, p.133-140, 1995.

72. ASTM D 412-98a: Standard Test Methods for Vulcanized Rubber and Thermoplastic Elastomers - Tension.

73. KURUVILLA, J.; MATTOSO, L.H.C. Recent developments in Natural Fibre Based Polymer Composites, Natural Polymers and Composites IV, edited by Mattoso, L.H.C.; Leão, A.; Frollini, E., São Carlos: Embrapa Instrumentação Agropecuária, UNESP, and IQSC/USP, p. 443-454, 2002.

74. CLARO NETO, S. Caracterizações Físico-Química de um Poliuretano Derivado de Óleo de Mamona Utilizado para Implantes Ósseos, Tese de Doutorado, Instituto de Química de São Carlos - USP, 1997. 
75. PAIVA, J.M.F.; TRINDADE, W.G.; FROLLINI, E.; PARDINI, L.C. Carbon Materials from Sisal and Sugarcane Bagasse Reinforced Lignophenolic Matrices Composites, Natural Polymers and Composites IV, edited by Mattoso, L.H.C.; Leão, A.; Frollini, E., São Carlos: Embrapa Instrumentação Agropecuária, UNESP, and IQSC/USP, p. 528-537, 2002.

76. MARCOVICH, N.E.; ARANGUREN, M.I.; REBOREDO, M.M. Some Aspects Related to the Processing of Natural Fibre - Polymer Composites -, Natural Polymers and Composites IV, edited by Mattoso, L.H.C.; Leão, A.; Frollini, E., São Carlos: Embrapa Instrumentação Agropecuária, UNESP, and IQSC/USP, p. 416-421, 2002. 